IZA DP No. 6643

What Determines the Share of Labour in National Income? A Cross-Country Analysis

Marta Guerriero

Kunal Sen

June 2012 


\title{
What Determines the Share of Labour in National Income? A Cross-Country Analysis
}

\author{
Marta Guerriero \\ IDPM, University of Manchester \\ Kunal Sen \\ IDPM, University of Manchester \\ and IZA
}

Discussion Paper No. 6643

June 2012

IZA

P.O. Box 7240

53072 Bonn

Germany

Phone: +49-228-3894-0

Fax: +49-228-3894-180

E-mail: iza@iza.org

Any opinions expressed here are those of the author(s) and not those of IZA. Research published in this series may include views on policy, but the institute itself takes no institutional policy positions.

The Institute for the Study of Labor (IZA) in Bonn is a local and virtual international research center and a place of communication between science, politics and business. IZA is an independent nonprofit organization supported by Deutsche Post Foundation. The center is associated with the University of Bonn and offers a stimulating research environment through its international network, workshops and conferences, data service, project support, research visits and doctoral program. IZA engages in (i) original and internationally competitive research in all fields of labor economics, (ii) development of policy concepts, and (iii) dissemination of research results and concepts to the interested public.

IZA Discussion Papers often represent preliminary work and are circulated to encourage discussion. Citation of such a paper should account for its provisional character. A revised version may be available directly from the author. 


\title{
ABSTRACT
}

\section{What Determines the Share of Labour in National Income? A Cross-Country Analysis}

\begin{abstract}
Recent evidence on functional income distribution suggests that the shares of capital and labour in national income vary considerably both over time and across countries. Specifically, there seems to be a general reduction in the labour share around the world, in particular from the mid-1980s onwards. Using fixed effects regression methods on a panel dataset covering 89 countries - both developing and developed - over the period 1970-2009, this study examines the mechanisms underlying the variability in the labour share. In particular, it focuses on the relationships between the labour share and measures of international trade and technological change. The results are robust across different specifications, for yearly data as well as 3- and 5-year averages, and after performing instrumental variable estimation. They suggest that trade openness and technological innovation have a positive and significant effect on the labour share. However, Foreign Direct Investments inflows and mechanisation seem to be negative drivers. Moreover, other factors, such as the level of economic development, education, and the strength of the regulations in the labour market, seem to also significantly influence functional distribution of income.
\end{abstract}

JEL Classification: E25, F16, J30

Keywords: labour share of income, functional income distribution, globalisation, technological progress

Corresponding author:

Marta Guerriero

Institute of Development Policy and Management

University of Manchester

Oxford Road

Manchester M13 9PL

United Kingdom

E-mail: Marta.Guerriero@postgrad.manchester.ac.uk 


\section{Introduction}

Functional income distribution has been put aside from the agenda of economic research for a long time. However, in recent years, a renewed interest has developed around it (Atkinson, 2009; Bentolila \& Saint-Paul, 2003; Daudey \& Garcia-Penalosa, 2007; Gollin, 2002; Krueger, 1999). In particular, a few studies documenting the recent decline of the labour share of income in advanced economies have captured the attention of policy discussions (Ben Bernanke and Robert Reich have frequently drawn interest to it), international organisations (EC, 2007; ILO, 2008; IMF, 2007) and the press (Bond \& Harding, 2011). The concern has become major with the wake and upsurge of the recent global economic crisis, and many of the industrialised countries experiencing millions of jobs losses and unemployment rates at their all-time high (Smeeding \& Thompson, 2010).

How can we explain these trends? What are the mechanisms which influence employment, wages and the labour share? Although there is no agreed theoretical framework on the determinants of functional distribution of income, a few possible explanations can be considered. In particular, recent studies have focused on the channels related to international trade and technological progress (Bentolila \& Saint-Paul, 2003; Ellis \& Smith, 2007; Guscina, 2006; Harrison, 2002).

As documented by a vast theoretical and empirical literature (Dollar \& Kraay, 2001), globalisation raises the level of income and fosters the entire national economy, improving living standards for the whole population. However, its specific effect on labour is controversial, given that not all groups of the society are able to take advantage of its benefits. In industrialised economies, trade with low income countries has been held responsible for the increase in wage differentials (experienced, for example, in Anglo-Saxon countries) and the decline of employment among low-skilled workers (in Continental Europe). In developing countries, instead, major concerns have been related to the quality of the jobs: trade is suspected to destroy "good" jobs in previously protected sectors while creating "bad" jobs in exporting industries (Ghose, 2003). According to these views, the growth of international trade has brought little benefits to workers worldwide. Yet, none of this is empirically well established (Freeman, 2003).

In the last couple of decades, many scholars have devoted extensive research efforts to understanding the consequences of trade liberalisation on income distribution (Harrison, McLaren, \& McMillan, 2011; Robbins, 1996; Sen, 2001; Wood, 1994). However, they have mainly focused on personal income distribution and wage inequality. To our knowledge, only 
a very limited number of studies have attempted assessing the impact of globalisation on the labour share (EC, 2007; Guscina, 2006; Harrison, 2002; IMF, 2007).

Moreover, to a great number of economists (Acemoglu, 2002; Bentolila \& Saint-Paul, 2003) technological change seems to be a more plausible explanation. They argue that, since the early 1980s, technological progress has become capital-augmenting, rather than labouraugmenting (as it was in the post-war era), and it has consequently boosted the returns to capital while depressing the returns to labour (IMF, 2001).

In conclusion, the debate is not yet resolved. In particular on developing countries, the literature is scarce and the evidence very ambiguous (Sen, 2001). This study intends to shed some light on the discussion and give an evaluation of the impact of international trade and technological change on functional income distribution.

The paper proceeds as follows. In sections 2 and 3 we discuss the literature on the determinants of functional income distribution. Section 4 explains the empirical specification and the data. Section 5 shows some descriptive statistics. Section 6 presents and discusses the results for yearly data as well as 3- and 5- year averaged data. Sections 7 and 8 show some robustness checks (several choices of alternative variables and interactions, as well as instrumental variable estimation). Finally, concluding remarks are derived in section 9.

\section{International trade, technological change and labour. The literature}

\subsection{Mainstream theory of international trade and income distribution}

Mainstream trade theory allows for the treatment of issues on functional income distribution. According to Heckscher and Ohlin's (H-O) general equilibrium model of trade between two countries with two factors of production and two goods (Ohlin, 1933), comparative advantage depends on the countries' differences in their relative abundance of factors: they will export goods whose production is intensive in the factor they are abundantly endowed. The H-O theory leads to the factor-price equalisation (Samuelson, 1948) theorem ${ }^{1}$ and the StolperSamuelson (Stolper \& Samuelson, 1941) theorem ${ }^{2}$. Trade-induced relative changes in product prices drive relative changes in factor prices: an increase in the price of the goods which are exported generates an increase in the real returns to the factor used intensively in the production of the goods, and a reduction in the returns to the other factor. Consequently,

\footnotetext{
${ }^{1}$ According to which trade would lead to the equalisation of the relative prices of the traded goods.

${ }^{2}$ Stating that international trade fully determines national factor prices, equal to average costs.
} 
owners of a country's abundant factor would gain from international trade, while owners of a country's scarce factor would lose. Labour-abundant developing countries have comparative advantage and will specialise in the production of labour-intensive goods, and vice versa capital-abundant industrialised countries in the production of capital-intensive goods ${ }^{3}$. Therefore, in developing countries, trade specialisation should benefit labour income, increasing wages (or employment, when there is a big stock of labour surplus) and the labour share. Instead, in industrialised countries, trade should reduce wages (or increase unemployment, when wages are artificially fixed) and boost relative incomes from capital ${ }^{4}$. Despite this framework has been widely accepted in the literature, many criticisms have been levelled against it, concerning its very restrictive set of assumptions (Bhagwati, 1994). The predictions hold in perfect internal competition of both goods and factor markets, with full employment of the resources and no barriers to trade (or natural barriers, such as transportation costs). The economies have the same tastes and therefore identical relative demands for the goods when faced with the same relative prices. Trading countries produce homogenous and perfectly substitutable products in the same industry, with identical technologies of production ${ }^{5}$ and constant returns to scale. There is perfect and costless mobility of factors within the countries, among the different industries, and perfect immobility of factors of production between the two countries. Finally, the framework relies on the assumption that traded goods are primarily final goods.

Several empirical studies have rejected the predictions of the $\mathrm{H}-\mathrm{O}$ theory, identifying contrary results. Ambiguous outcomes have also been found by those who have tried to produce more realistic versions of the model, relaxing one or more assumptions.

In particular, instead of defining factor abundance in a global sense, Melvin (1968) introduces the concept of 'cones of diversification' (Davis, 1996). Wide divergences in relative factor endowments may preclude factor price equalisation for the world as a whole. It is therefore necessary to consider the relative position of a given country compared to the other countries within the same “cone”. Trade patterns for each country will vary according to their relative factor abundance inside the cone. Therefore, the distributional consequences may be opposite for countries within the same cone of diversification.

\footnotetext{
${ }^{3}$ Empirical evidence supports this pattern of specialisation, though developing countries have seen an increase in the capital intensity of their exports over time (Ghose 2003).

${ }^{4}$ Standard trade theory and the $\mathrm{H}-\mathrm{O}$ framework are also held responsible for the rise in income inequality (personal distribution of income) in industrialised countries. The mechanism is very similar, if we consider the two factors of production to be low-skilled and high-skilled labour.

${ }^{5}$ This simplification rules out many situations when trade is about acquiring access to products which are otherwise unavailable.
} 
Another objection to the use of the H-O theory in relation to trade between developed and developing countries derives from a model proposed by Feenstra and Hanson (1996), where goods are ordered in a continuum corresponding to the different levels of factor intensity. Some products could be labour-intensive from a developed country's point of view, but capital-intensive from an emerging country's perspective. Finally, another possible extension of the H-O theory is provided by 3-factor models, which include also land among the factors of production, together with capital and labour (Leamer, 1987; Wood, 2002) ${ }^{6}$.

On an empirical level, many studies have tried to test the $\mathrm{H}-\mathrm{O}$ model and its consequences on wage inequality (Burtless, 1995; Cline, 1997; Harrison, et al., 2011; Krugman, 2008; Lawrence, 2008; Richardson, 1995; Robbins, 1996; Slaughter, 1999). However, not much has been done on functional income distribution.

\subsection{International trade and functional income distribution: other mechanisms}

Other theoretical frameworks explain alternative ways international trade may affect the labour share. They are particularly interesting because they do not consider only North-South trade $^{7}$, as the H-O model, but all types of trade, regardless of the economic structure and the identity of their trade partners.

On one side, we can put the focus on product markets. The intensified competition originated by international trade may decrease mark-ups of prices and profits over wages. Kalecki's theory of distribution (1938) claims that the greater the degree of monopoly the higher the mark-up. A rising degree of monopoly over time would lead to real wages growing more slowly than productivity and a rising capital share; on the contrary, increased competition derived from the opening up of product markets to international trade would increase the labour share (Azmat, Manning, \& Reenen, 2011).

Moreover, workers may be better off because of the positive effects from enhanced trade and productivity (Lewer \& Berg, 2003), which may lead to a substantial increase in the economy's income. Moreover, especially in the South, the stimulus in export growth following the process of liberalisation may ease the "foreign exchange constraint" and consequently promote growth of the manufacturing sector as a whole (Ghose, 2000), contributing to overall economic growth, increase in labour demand and creation of higher levels of employment across all industries.

\footnotetext{
${ }^{6}$ Or distinguish between the different qualities of labour (skilled and unskilled labour).

${ }^{7}$ Which, as many economists argue, still accounts for a small portion of overall trade flows.
} 
On the other side, there is the claim that globalisation adversely affects the relative bargaining position of labour. Rodrik (1997) and Slaughter (1999) argue that reduced barriers to trade accentuate the asymmetries between groups that can cross international borders (owners of capital and a few highly skilled workers) and those who cannot (the greater majority of workers). Globalisation makes the demand for workers' services flatter and more elastic, because they are more easily substitutable with the services of other people across national boundaries. Their bargaining power will be consequently reduced, as well as their wages $^{8}$. A few empirical studies have indeed found a negative correlation between trade and labour share of income (Guscina, 2006; Harrison, 2002; Jaumotte \& Tytell, 2007; Jayadev, 2007), especially in industrialised countries.

Finally, as already mentioned, the recent processes of outsourcing, off-shoring and two-way trade in the production process have considerably modified the traditional mechanisms. The effects are controversial. One hypothesis is that, when firms reallocate capital to other countries for production, they outsource labour intensive production to countries with lower wages and consequently decrease domestic demand of labour and the labour share (Jayadev, 2007). Another hypothesis, instead, is that, when companies in industrialised economies offshore some of their activities to the South, developing countries would take over only labourintensive portions of skilled-intensive industries (Krugman, 2008), so no substantial change occurs in the pattern of trade and specialisation of developed and developing economies suggested by mainstream theory. Finally, a third hypothesis (Grossman \& Rossi-Hansberg, 2008) is that off-shoring and trade in intermediates are Pareto-improving phenomena, generating productivity-enhancing effects for domestic labour, accelerating innovation and improving welfare.

In conclusion, there is no established theoretical framework on the effects of trade on income distribution. To a great number of scholars working on personal income distribution, skillbiased technological change seems to be a more plausible explanation for the reduction of low-skilled wages around the world (Acemoglu, 2002; Berman \& Machin, 2000; Wood, 1994, 1995). In relation to functional income distribution, we may be in the presence of some form of "capital-biased technological change". The $\mathrm{H}-\mathrm{O}$ assumption of homogenous production functions can be released to allow for international openness to facilitate technology diffusion from high-income to low-income countries. This may occur through two

\footnotetext{
${ }^{8}$ For example, given that fixed costs of relocating or investing abroad are much larger for workers than for capital, managers gain more option for investing, both in terms of geographical location and of the content of investment (Diwan, 2001; Jayadev, 2007). They may use the threat of delocalising their production plants to keep down the level of wages.
} 
channels: first, the increase in international flows of capital may promote technological upgrading (Acemoglu, 2002); second, firms may be able to acquire knowledge of international best practice when exporting into foreign markets.

\subsection{The effect of technological progress}

Technological change and international trade are not independent of each other. On one side, technological change may be trade-induced and innovation is a channel through which trade affects income distribution (Dinopoulos \& Segerstrom, 1999). On the other side, trade may be actually determined by technology gaps (Blecker, 2003). In some industries, with no standardised production processes, overall competitiveness is a result of technological capabilities: it is the acquisition of technological capabilities, and not factor endowments, to determine the impact of trade on labour.

It is generally argued (Bentolila \& Saint-Paul, 2003; Guscina, 2006; Lawless \& Whelan, 2011) that, since the early 1980s, technological change has become capital-augmenting, rather than labour-augmenting (as it was traditionally in the post-war era). Consequently, it has been the driving force behind the decline of the labour share around the world, especially after the introduction of Information and Communication Technologies (ICTs) and other new technologies (IMF, 2001). However, while machineries are generally substitutes to unskilled labour, they are also complements to skilled labour. Moreover, the introduction of new machines and new technology means extra-training and extra-learning for those people who have to work with them, therefore, an increase in their levels of education and their labour productivities (IMF, 2007). It is still not clear whether one or the other effect dominates and what the overall impact on labour will be (Arpaia, Pérez, \& Pichelmann, 2009).

A recent study (Ellis and Smith, 2007) has proposed the hypothesis that ongoing technological progress and mechanisation, in particular in ICT-related capital goods, have increased the rate of depreciation and obsolescence of capital goods, putting firms in a stronger bargaining position compared to the labour force. Machines are costly to install. However, because of their very fast rate of innovation, firms decide to change them very frequently: once they are obsolete, they are discarded. Given that production takes place by matching machinery capital with workers, workers are often too expensive compared to the low productivity of the old machines they are working with. So, changes in employment levels are necessary to make best use of the new technology. Consequently, firms are in a much stronger bargaining position relative to workers and the labour share will decline.

Computerisation and mechanisation are mainly associated to one type of technological progress, which leads to the reduction in the number of units of labour required. There is also 
another form of technological change, more related to the creation of innovation than the introduction of machineries, which generally boosts productivity and competition in the product markets, and which generates positive effects on employment and labour demand. Innovation may therefore lead to a considerable increase in the overall economy's income, as well as in the labour share. Moreover, given the recent growth in the rate of innovation in ICT technologies, this process may have accelerated in recent years.

\section{Other determinants of the labour share}

\subsection{Economic development}

In their two-sector models, Lewis (1955), Kravis (1959) and Kuznets (1955) provide an explanation why the level of economic development may be one of the most important determinants of the labour share. Poor economies are dominated by a traditional agricultural sector with very low wages and a big surplus of labour (Lewis, 1955). The few capitalists in the modern sector are able to hire labour at minimal wages; therefore, productivity gains are not compensated by wage increases (Jayadev, 2007; Maarek, 2010; Ortega \& Rodriguez, 2006): the labour share is consequently down at very low levels. As the economy develops, productivity increases, and greater segments of the workforce start moving from the traditional agricultural sector into positions of organised wage labour in the modern sector. Wages will rise, as well as employment, because of the presence of unlimited supply of labour: an increasingly larger share of income will be earned by workers as opposed to entrepreneurs (Kravis, 1959; Kuznets, 1955). However, with the economy growing more and more, the mechanism will necessarily reduce its magnitude and other dynamics will come into place: the effect of rising wages is stronger for low levels of development (Daudey \& Garcia-Peñalosa, 2007).

\subsection{Labour market regulations}

Labour markets are generally non-competitive and characterised by market failures which create rents, to be distributed between capital and labour in relation to their relative bargaining power. The majority of the literature argues that pro-worker labour institutions have an important and positive redistributive role in the economy, restoring the equilibrium between capital and labour, and counteracting possible negative effects generated by asymmetries in economic power between workers and employers. When the bargaining position of the workers is weak, governments may intervene to correct these failures, protecting vulnerable categories of workers by increasing their wages and their levels of 
employment (ADB, 2005; EC, 2007). We consequently expect a positive relationship between regulations in the labour market and the labour share. However, some economists have critiqued this framework, claiming that labour regulations produce ambiguous effects on employment (Nickell, 1999; Besley and Burgess, 2004) and poorly designed institutions may generate 'perverse' effects, given that they impact only on the organised sector of the economy (Dougherty, 2008).

\subsection{Investment}

The Kaldorian theory (Kaldor, 1955-1956; Pasinetti, 1962) suggests that factor returns adjust in order to finance investment, which is exogenously determined. If real investment demand increases, income distribution will support the right level of savings and make the necessary finance come forth, shifting towards groups with higher savings propensity. Being the marginal propensity to save out of profits greater than the marginal propensity to save out of wages, an increase in investment may cause redistribution from wages to profits, and consequently generate an increase in the rate of profit and a fall in the real wage. Functional income distribution will shift to favour profit recipient over workers.

\subsection{Education}

We also know from the literature (Daudey \& Garcia-Peñalosa, 2007; Diwan, 2001; Luo \& Zhang, 2010) that the labour share is affected by the amount of human capital that workers possess. Higher educational attainment influences labour through its effect on wages and employment. An increase in the level of human capital, raising the levels of wages and employment, is expected to increase the numerator of the share (Daudey \& Garcia-Penalosa, 2007).

\section{Econometric methodology, empirical specification and data}

\subsection{The measurement of the labour share}

'Income shares' or 'factor shares' refer to the shares of national income which reward the different factors of production. Thus, the labour share of income "shows how much of national income accrues to labour” (Lübker, 2007). Though considered elementary to determine, a few issues arise from its measurement (Krueger, 1999).

This study constructs a dataset of the labour share around the world following the methodologies proposed by Krueger (1999), Glyn (2009) and Gollin (2002), and using data from the United Nations National Accounts Statistics. This database consists of a series of 
analytical national accounts tables for 178 countries from 1946 onwards, prepared by the Statistics Division of the Department for Economic and Social Affairs of the UN Secretariat. Despite the presence of some comparability issues (Hartwig, 2006), its estimations are incredibly meaningful measures and have already been used in the literature on functional income distribution (Bernanke \& Gürkaynak, 2001; Diwan, 2001; Harrison, 2002; Jayadev, 2007).

The denominator of the labour share is the income aggregate, Gross Value Added at basic prices, net of capital consumption and measured at factor costs. The numerator, instead, is the compensation of employees adjusted for self-employment income. In order to do so, because of lack of data on income from the self-employed, Gollin (2002) suggests using data on the composition of the workforce from the ILO Yearbooks of Labour Statistics and imputing average employees' compensation to all those workers who hold self-employment jobs. This study proposes an adjustment to Gollin's measurement, which consists in attributing average employees' wage to all the self-employed excluding employers, which are assumed here to earn only capital income ${ }^{9}$.

The compiled labour share dataset is an unbalanced panel containing 1918 observations covering 89 countries, both developed and developing, over the period 1970-2009.

Contrary to the traditional assumption of stability of factor shares (see Figure1), the data present medium- and long- term evidence of considerable variability. Not only have factor shares varied over time, but there also seems to be a general declining trend over the last few decades, in particular from the mid-1980s onwards.

Figure1. Average values of LS6 over time

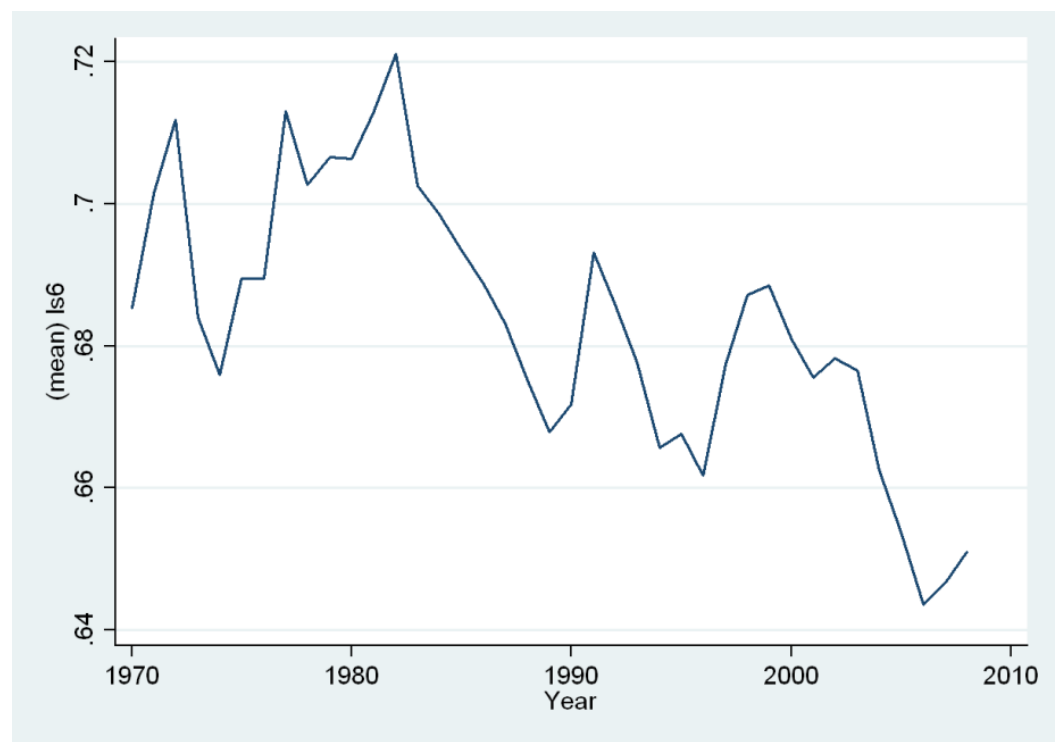

\footnotetext{
${ }^{9}$ See Appendix A for a more comprehensive description of the data.
} 


\subsection{Econometric methodology and empirical specification}

The previously described measure of labour share shows evidence of both between and within variation (see Appendix B for its variance decomposition). Consequently, by utilising panel data methods, we are able to address both cross-country ("long-run”) and temporal ("short-run”) effects. From an econometrics perspective, several benefits originate from the use of panel methods over conventional cross-sectional and time-series methods. Firstly, panel data are able to account for individual differences, or heterogeneity (Baltagi, 2005), and can reduce the problem of omitted or unobserved variables. Secondly, they are more informative and efficient than pure time-series or pure cross-sectional datasets, and their econometric analysis is better able to capture the complexity of economic behaviours (Hsiao, 2003). Finally, they provide the possibility of producing more accurate predictions for individual outcomes.

The fixed effects (or within) estimation is the preferred method in this analysis. Its attraction relies on the fact that it allows to account for a limited form of endogeneity: the correlation between the unobserved heterogeineity and the explanatory variables, caused for example by cultural, social and/or institutional factors which cannot be directly measured. Moreover, because it removes any time-invariant variable, it also eliminates country-specific idiosyncrasies in the data used to compute the labour share.

The objective of the paper is to examine the determinants of the labour share, focusing in particular on international trade and technological change. The proposed empirical specification is the following:

$$
L S_{i t}=\beta_{0}+\text { Trade }_{i t} \beta_{1}+\text { Technology }{ }_{i t} \beta_{2}+\sum_{k} \delta_{k} X_{i k t}+u_{t}+\alpha_{i}+\varepsilon_{i t}
$$

where $i$ and $t$ designate country and time period respectively, $L S$ is the labour share, international trade and technological change are the key explanatory variables, while $X_{k}$ are a set of control variables. The error terms $\alpha_{i}$ and $u_{t}$ capture the country-invariant (country fixed effect) and time-invariant (year effect) components of the error term respectively, while $\varepsilon_{i t}$ is the white noise component of the error term. An intercept $\beta_{0}$ has been explicitly included.

The other explanatory variables, as identified in the review of the literature, include per capita income, its squared value, labour market institutions, investment and education. Moreover, total population has been added as a control variable in the regression, as a proxy for the 
market size of the economy which can influence the effect of trade (Frankel \& Romer, 1999). It is in fact possible that bigger countries may engage in more trade than others, and this may lead to distortions in the estimations of the effects of trade.

Therefore, the benchmark model to be estimated is:

$$
\begin{aligned}
& L S_{i t}=\beta_{0}+\text { Trade }_{i t} \beta_{1}+\text { Technology }_{i t} \beta_{2}+\operatorname{Ln}(G D P)_{i t} \beta_{3} \\
& +\left[\operatorname{Ln}(G D P)^{2}\right]_{i t} \beta_{4}+\text { Lab. institutions }{ }_{i t} \beta_{5}+\text { Investment }_{i t} \beta_{6} \\
& + \text { Education }_{i t} \beta_{7}+\operatorname{Ln}(\text { population })_{i t} \beta_{8}+u_{t}+\alpha_{i}+\varepsilon_{i t}
\end{aligned}
$$

The model accounts for time fixed effects $\left(u_{t}\right)$ over the $T$ years including $T-1$ year dummy variables in the tested regressions. The motivation is that time common trends and annual specific shocks might affect the investigated relationships ${ }^{10}$. Moreover, robust standard errors have been used (White, 1980), in order to correct for the presence of arbitrary heteroskedasticity of the residuals, after performing a test for group-wise heteroskedasticity on the benchmark specification with year dummies (Greene, 2008).

Finally, the choice of using the fixed effects estimation has been tested producing random effects estimates and performing the Hausman test, which has shown the presence of highly significant difference between the two estimators and therefore the need to used fixed effects.

\subsection{Data}

The main measure of international trade used in the analysis ${ }^{11}$ is a trade outcome variable from the Summer-Heston dataset, or Penn World Table (PWT) 7.0 (Heston, Summers, \& Aten, 2011; Summers \& Heston, 1988, 1991): total trade as a percentage of GDP. This is a standard and frequently used proxy for openness to trade (Guscina, 2006). Another indicator is also considered, from the Sachs and Warner dataset “Trade Openness Indicators” (Sachs \& Warner, 1995), widely used in empirical research (Rama, 2003). Moreover, we use data from the World Bank World Development Indicators (WDI) on net inflows and outflows of Foreign Direct Investments (as a percentage of GDP). Finally, we also utilise the KOF Index of Globalisation (Dreher, 2006; Dreher, Gaston, \& Martens, 2008), a wider index of globalisation extensively used in recent literature (Bergh \& Nilsson, 2010; Dreher \& Gaston, 2008; Hessami, 2011). Its sub-index on restrictions on trade has been isolated from the overall index, as a measure of trade restrictions and regulations.

\footnotetext{
${ }^{10}$ Their inclusion has been chosen after testing for their joint significance while running the fixed effects estimation on the benchmark specification.

${ }^{11}$ See Appendix A for a more comprehensive description of the data.
} 
The natural logarithm of total population (as a proxy for the market size of the economy) is also added in the regression as a control variable, with yearly data from the United Nations, Department of Economic and Social Affairs, Population Division, Population Estimates and Projections Section.

Concerning technological progress, we first take into account two alternative proxies for technological innovation, collected from the World Bank WDI. The main variable of choice is the number of patent applications; while the second variable is the expenditure for research and development. As argued in Griliches (1990), they are both good indicators of inventive activity, widely used in the literature to measure and understand technological change (Barrell \& Pain, 1997; Bound, Cummins, Griliches, Hall, \& Jaffe, 1984; Pakes \& Griliches, 1984; Schmookler, 1966) ${ }^{12}$. In addition, in order to address mechanisation, which is a second channel of technological change, we include another proxy: machinery and equipment capital (as a percentage of the overall capital stock), collected from an earlier version of the PWT 6.2 (Heston, Summers, \& Aten, 2006).

The natural logarithm of real GDP per capita is used as a proxy for structural determinants correlated with levels of income. The data have been collected from the PWT 7.0 (Heston, et al., 2011). In order to consider the possibility of decreasing returns, the squared value of the measure has also been added to the regressors.

Campos and Nugent's LAMRIG (Labour Market Rigidities) Dataset is the source of the variable on labour market regulations (Campos \& Nugent, 2011). LAMRIG dataset, which provides data for both developed and developing countries over a long period of time, is new and it has not been used in the literature yet. To my knowledge, there is only another database of this kind on labour market rigidities around the world, compiled by Rama and Artecona in 2002 and covering the period 1970-1996 (Forteza \& Rama, 2006; Rama \& Artecona, 2002) ${ }^{13}$. As a measure of the level of investment, the investment share of GDP per capita has been used, derived from the PWT 7.0 (Heston, et al., 2011).

\footnotetext{
${ }^{12}$ A few problems arise from the use of patents applications in economic analysis. Firstly, intrinsic variability: patents differ greatly in their technical and economic significance (Griliches, 1990) and there is no good procedure for "weighting" them appropriately. Secondly, not all the inventions are patentable and/or patented. Despite the problems, patents remain a unique resource for the analysis of technological change. For no other variable we possess the same quantity of available data, accessibility and detail (Griliches, 1990). Compared to patents, expenditures for R\&D tend to slightly overestimate the real value of inventive activity, given that the majority of the expenditures concern "development" and not "research".

${ }^{13}$ However, its index, being mainly based on the ratification of the fundamental ILO Conventions, has been criticized of suffering from major problems. First, it does not have big variation over time. Second, once the country has signed all the Conventions, the value of the index cannot change any more. Third, the ratification of the Conventions does not imply the country's adherence to their contents unless the country puts them into practice through its national regulations.
} 
Finally, to measure the level of education, we utilise average schooling years in the total population aged 25 or over, taken from the Dataset on Educational Attainment in the World (Barro \& Lee, 2010), a database extensively used in the literature (Barro, 1991; Barro \& Salai-Martin, 2004; Cohen \& Soto; Wood \& Ridao-Cano, 1999).

\section{Trade, technology and labour. Some stylised facts}

Appendix B contains summary statistics for all the variables utilised in the study, and shows pair-wise coefficients of correlation between the dependent variable, labour share (rescaled ranging from 0 to 100), and each of the regressors in the benchmark model, for the whole period.

In accordance with recent literature, there seems to be a negative, even if not large in magnitude, correlation between the labour share and the PWT measure of openness to trade. However, when we examine year-by-year bivariate scatters (see Appendix C), the relationship does not seem to be clear-cut, especially after identifying a few outliers and eliminating them from the scatters (see Appendix D). In conclusion, cross-country summary statistics show ambiguous results. The same happens with time-series data for each single country (see Appendix G). Figure2 shows two examples of the evolution of labour share and openness, plotted together over time. The story for the two countries (a middle-income and a high-income country, Algeria and Australia) seems to be exactly the opposite. In the former, decreasing labour share is accompanied by decreasing openness to trade, while in the latter, decreasing labour share is associated to increasing international trade.

Figure2. Labour share and trade openness.
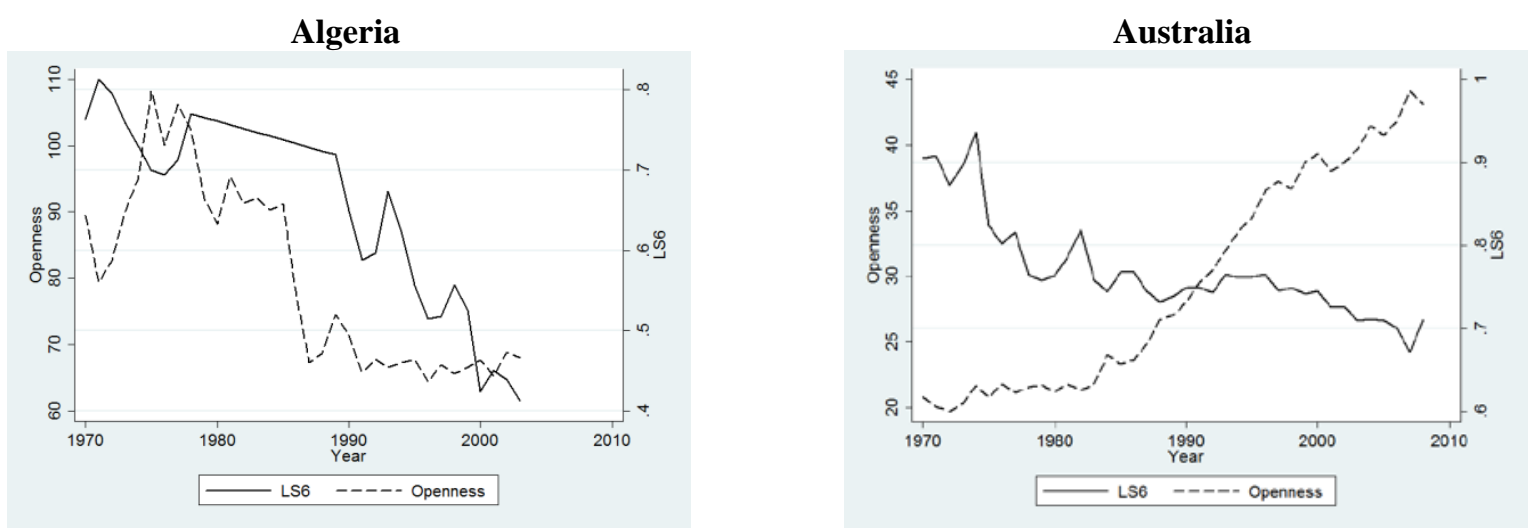

Source: Author's calculations.

Appendices $\mathrm{E}$ and $\mathrm{F}$ show bivariate scatters of labour share and technological progress. Contrary to what is predicted by the skill biased technological change argument, higher levels of technology seem to be associated to higher levels of the labour share. The correlation coefficients of the labour share with both the WDI variables of innovative 
technology are positive (0.1503 with patent applications and 0.3039 with expenditure in research and development) and strongly significant. Finally, also observing time-series data for each single country, we seem to detect similar trends: the labour share increases (or decreases) together with the variable of technological progress (see Appendix H).

\section{Results}

\subsection{Fixed effects estimations. Yearly data}

Table1 displays the results for the fixed effects estimation of the model, with annual data. Columns differ according to the variables progressively included in the specification: trade openness (column 1), patents applications (column 2), level of economic development (column 3) and its squared value (column 4), labour market regulations (column 5), investment (column 6) and level of education (column 7). Population and time fixed effects have been introduced as controls across all the specifications. A number of significant results emerge across specifications ${ }^{14}$.

The coefficient on international openness seems to be positive and strongly significant across almost all the specifications, even if not very big in size. This suggests that international trade is an important factor in driving labour shares; and, contrary to what has been stated by previous literature (Guscina, 2006; Harrison, 2002), it has a positive influence on labour. The labour share seems to be significantly higher in those countries which are more engaged in trade (from the benchmark regression, one percentage point increase in trade openness is associated to an expansion of approximately 0.05 percentage points in the labour share). As previously explained, it is plausible to think that the global net effect of globalisation is generally positive (Dollar \& Kraay, 2001), especially in the South, where trade may contribute to overall economic growth and generate an increase in labour demand and in the levels of employment.

Also the relationship with patents applications seems to be positive and significant. Whether considered only together with trade (column 2) or together with all the other regressors (columns 3 to 7), the coefficient, even if very small, is always positive and highly significant. Higher technological progress is therefore another important determinant of higher labour shares. From the results for the baseline specification (column 7), an increase of 1000 patents

\footnotetext{
${ }^{14}$ As robustness checks, the same estimations have been performed after the detection and deletion of some influential and outlier observations from the data pool. No difference in the results has been found. Moreover, the results obtained in the benchmark estimation of my adjusted measure of labour share have been compared to the results obtained in the estimations of other measures of labour share, previously used in the literature, again with no significant change in the results.
} 
applications in the year is associated to a rise of slightly more than 0.04 percentage points in the labour share. 
Table1. Heteroskedasticity robust FE regressions. Alternative specifications.

\begin{tabular}{|c|c|c|c|c|c|c|c|}
\hline \multirow{2}{*}{$\begin{array}{c}\text { Dep. var.: } \\
\text { LS (\%) }\end{array}$} & \multirow{2}{*}{$\begin{array}{c}\text { Trade } \\
\text { openness } \\
\text { (1) }\end{array}$} & \multirow{2}{*}{$\begin{array}{c}\text { Technological } \\
\text { progress } \\
(2)\end{array}$} & \multicolumn{2}{|c|}{ Economic development } & \multirow{2}{*}{$\begin{array}{c}\text { Labour market } \\
\text { institutions } \\
\text { (5) }\end{array}$} & \multirow{2}{*}{$\begin{array}{c}\text { Investment } \\
\text { (6) }\end{array}$} & \multirow{2}{*}{$\begin{array}{c}\text { Human capital } \\
\text { (7) }\end{array}$} \\
\hline & & & (3) & (4) & & & \\
\hline Openness & $\begin{array}{l}\mathbf{0 . 0 4 4 6}^{\text {*** }} \\
(0.00953)\end{array}$ & $\begin{array}{c}\mathbf{0 . 0 2 0 0}^{*} \\
(0.0103)\end{array}$ & $\begin{array}{c}0.0142 \\
(0.0107)\end{array}$ & $\begin{array}{l}\mathbf{0 . 0 2 0 3}^{*} \\
(0.0107)\end{array}$ & $\begin{array}{l}\mathbf{0 . 0 3 5 0} \\
(0.0147)\end{array}$ & $\begin{array}{l}\mathbf{0 . 0 3 5 0}^{* *} \\
(0.0147)\end{array}$ & $\begin{array}{c}\mathbf{0 . 0 4 9 7}^{\text {****}} \\
(0.0145)\end{array}$ \\
\hline Patents & & $\begin{array}{l}\mathbf{0 . 0 0 0 0 4 5 0} \text { (*** }^{* *} \\
(0.00000942)\end{array}$ & $\begin{array}{l}\mathbf{0 . 0 0 0 0 3 6 7} \\
(0.00000824)\end{array}$ & $\begin{array}{l}\mathbf{0 . 0 0 0 0 4 1 9}^{* * *} \\
(0.00000859)\end{array}$ & $\begin{array}{l}\mathbf{0 . 0 0 0 0 4 0 9}^{* * *} \\
(0.00000910)\end{array}$ & $\begin{array}{l}\mathbf{0 . 0 0 0 0 4 0 8}^{\text {****}} \\
(0.00000922)\end{array}$ & $\begin{array}{l}\mathbf{0 . 0 0 0 0 4 1 6}^{* * *} \\
(0.00000888)\end{array}$ \\
\hline Ln(Gdp) & & & $\begin{array}{c}5.397^{* * *} \\
(1.795)\end{array}$ & $\begin{array}{l}\mathbf{4 1 . 3 1}^{* * *} \\
(11.62)\end{array}$ & $\begin{array}{l}\mathbf{5 4 . 4 8}^{* * *} \\
(16.05)\end{array}$ & $\begin{array}{l}54.45^{* * *} \\
(16.08)\end{array}$ & $\begin{array}{l}\mathbf{5 3 . 6 1} \\
(14.95)\end{array}$ \\
\hline$[\operatorname{Ln}(\mathrm{Gdp})]^{2}$ & & & & $\begin{array}{l}-2.045^{* * *} \\
(0.657)\end{array}$ & $\begin{array}{c}-2.710^{* * *} \\
(0.921)\end{array}$ & $\begin{array}{c}-2.704^{* * *} \\
(0.925)\end{array}$ & $\begin{array}{c}-2.795^{* * *} \\
(0.863)\end{array}$ \\
\hline Lab. reg. index & & & & & $\begin{array}{c}0.0371 \\
(0.0368)\end{array}$ & $\begin{array}{c}0.0367 \\
(0.0366)\end{array}$ & $\begin{array}{l}\mathbf{0 . 1 1 4} \\
(0.0360)\end{array}$ \\
\hline Investment & & & & & & $\begin{array}{l}-0.00469 \\
(0.0625)\end{array}$ & $\begin{array}{l}-0.00305 \\
(0.0616)\end{array}$ \\
\hline Schooling & & & & & & & $\begin{array}{l}3.857^{* * *} \\
(0.529)\end{array}$ \\
\hline Ln(popul) & $\begin{array}{c}-6.524^{* * *} \\
(2.148)\end{array}$ & $\begin{array}{l}-15.40^{* * *} \\
(3.471)\end{array}$ & $\begin{array}{c}\mathbf{- 1 3 . 3 8} \\
(3.484)\end{array}$ & $\begin{array}{c}-17.32^{* * *} \\
(3.531)\end{array}$ & $\begin{array}{c}-15.13^{* * *} \\
(4.220)\end{array}$ & $\begin{array}{c}-15.10 \\
(4.213)\end{array}$ & $\begin{array}{c}-19.18 \\
(4.255)\end{array}$ \\
\hline _cons & $\begin{array}{l}\mathbf{1 2 1 . 0}^{* * *} \\
(19.02)\end{array}$ & $\begin{array}{l}\mathbf{2 0 7 . 4} \\
(31.65) \\
\end{array}$ & $\begin{array}{l}141.7^{* * *} \\
(38.04)\end{array}$ & $\begin{array}{c}19.94 \\
(57.10) \\
\end{array}$ & $\begin{array}{l}-65.12 \\
(65.60) \\
\end{array}$ & $\begin{array}{l}-65.61 \\
(65.65) \\
\end{array}$ & $\begin{array}{l}-50.72 \\
(61.48) \\
\end{array}$ \\
\hline Year dummies & Yes & Yes & Yes & Yes & Yes & Yes & Yes \\
\hline$N$ & 1842 & 1374 & 1374 & 1374 & 1144 & 1144 & 1134 \\
\hline$N$ countries & 84 & 71 & 71 & 71 & 67 & 67 & 65 \\
\hline$R^{2}$ & 0.066 & 0.090 & 0.102 & 0.111 & 0.108 & 0.108 & 0.152 \\
\hline$F$ test & $2.00 * * *$ & $2.44 * * *$ & $2.59 * * *$ & $3.08 * * *$ & $2.63 * * *$ & $2.57 * * *$ & $4.03 * * *$ \\
\hline
\end{tabular}

\begin{tabular}{l}
\hline Source: Author's calculations. \\
Please note: Standard errors in parentheses. ${ }^{*} \mathrm{p}<0.10,{ }^{* *} \mathrm{p}<0.05,{ }^{* * *} \mathrm{p}<0.01 . R^{2}$ is the within $\mathrm{R}^{2}$.
\end{tabular} 
In conclusion, also technological progress seems to have a predominant positive effect on labour. But are changes in technology exogenous to trade? The results in column 2 seem to show that, as soon as we introduce patents applications in the specification, the coefficient on international trade loses some of its significance and becomes half its size: it is therefore likely to think that the two variables are highly correlated and may reciprocally determine each other. In reality, the coefficient of correlation between the two variables does not seem to be positive (see Appendix B) and the results from the other columns in Table1 demonstrate that both patents and openness to international trade significantly influence the labour share.

As expected, the coefficient on per capita income (columns 3 to 7) is positive and statistically significant. With the introduction of all the controls, the magnitude of the effect becomes relatively large. Moreover, the quadratic relationship seems to hold, being also the coefficient on the squared variable highly significant across all the specifications. From the results in column 7, labour share increases with GDP per capita, but at a decreasing rate of return, until a peak at around 14,700 2005 I\$/person, approximately equivalent to today's per capita income in Russia.

Furthermore, the results for the benchmark specification (column 7) confirm our expectations concerning labour market institutions and years of schooling, showing positive and strongly significant coefficients. One percentage point increase in the index of labour market regulations is associated to a rise of approximately 0.11 percentage points in the labour share, and therefore the transition from a completely flexible market to a completely regulated market is associated to 11 percentage point increase in the labour share. Moreover, a one year increase in average schooling in the total population aged 25 or over leads to an increase of approximately 3.86 percentage points in the labour share.

Investment shows the expected sign (columns 6 and 7). However, no impact has been found for the coefficients, which are very small in magnitude and not significantly different from zero across the alternative specifications. This may be due to the presence of multicollinearity in the data, and the fact that investment is significantly correlated to other variables in the specification, for example trade openness.

Finally, the coefficient on population is negative, highly significant and relatively large in size. From the baseline specification (column 7), a 1\% increase in the total population is associated to a decrease of approximately 19.18 percentage points in the labour share. Countries with a large population are very likely to possess surpluses in 
their labour force (Lewis, 1955). Therefore, because of the abundance of labour, wages will be low, and consequently the labour share will also be low.

With respect to the year dummies in the benchmark specification (column 7), their coefficients are generally negative, hardly ever significant until the mid-to-late 1980s and then strongly significant in the 1990s and 2000s. Time dummies control for common trends or "systematic" shocks, and describe shifts in the function due to "external effects". It is possible to think that they are capturing shocks in technology, considering the fact that their significance becomes high in the late-1980s, contemporaneously with the start of the IT-revolution era and the accelerated adoption of capital-augmenting ICT technologies around the world (IMF, 2001; EC, 2007; Ellis \& Smith, 2007; Guscina, 2006).

\subsection{Fixed effects estimations. Non-overlapping averages}

In order to eliminate the effects of temporary external shocks, the panel has been restructured into non-overlapping three-year (for a maximum of 14 sub-periods) and five-year (for a maximum of 8 sub-periods) averages. Table2 provides a description of overall, within and between variations of the labour share with the restructured data. The variability of the data does not seem to change noticeably. Overall- and betweenvariations remain the same or even slightly increase compared to the yearly data. Within-variation, as expected, is reduced, in particular in the 5-year averages case.

Table2. Labour share variability. 3- and 5-year averages.

\begin{tabular}{ccccccc}
\hline Variable & & Mean & St. Deviation & Min & Max & Observations \\
\hline \multirow{2}{*}{ 3-year averages: } & & & & & & \\
\hline Labour share (\%) & Overall & 67.69426 & 14.36905 & 18.52000 & 99.13667 & $N=688$ \\
& $\begin{array}{c}\text { Between } \\
\text { Within }\end{array}$ & & 14.09977 & 28.84000 & 92.16417 & $n=89$ \\
& & 6.579627 & 40.95836 & 92.09807 & $\bar{T}=7.73034$ \\
\hline & & & & & & \\
5-year averages: & & & & & & \\
\hline Labour share (\%) & Overall & 67.49555 & 14.48557 & 18.16000 & 97.85250 & $N=448$ \\
& Between & & 14.12173 & 27.36200 & 92.17896 & $n=89$ \\
& Within & & 6.156144 & 42.47530 & 87.4093 & $\bar{T}=5.03371$ \\
\hline Source: Author's calculations. & & & & &
\end{tabular}

Table3 reports the results when the baseline specification is estimated with the restructured data. Even if averaging the sample leads to considerably smaller sample sizes, the results are still very significant and clearly in line with the previously obtained results. What is remarkable about the table is how little the transformations in the data change the basic results. 
Table3. Heteroskedasticity robust FE estimations using medium-term data (non-overlapping 3- and 5-year averages).

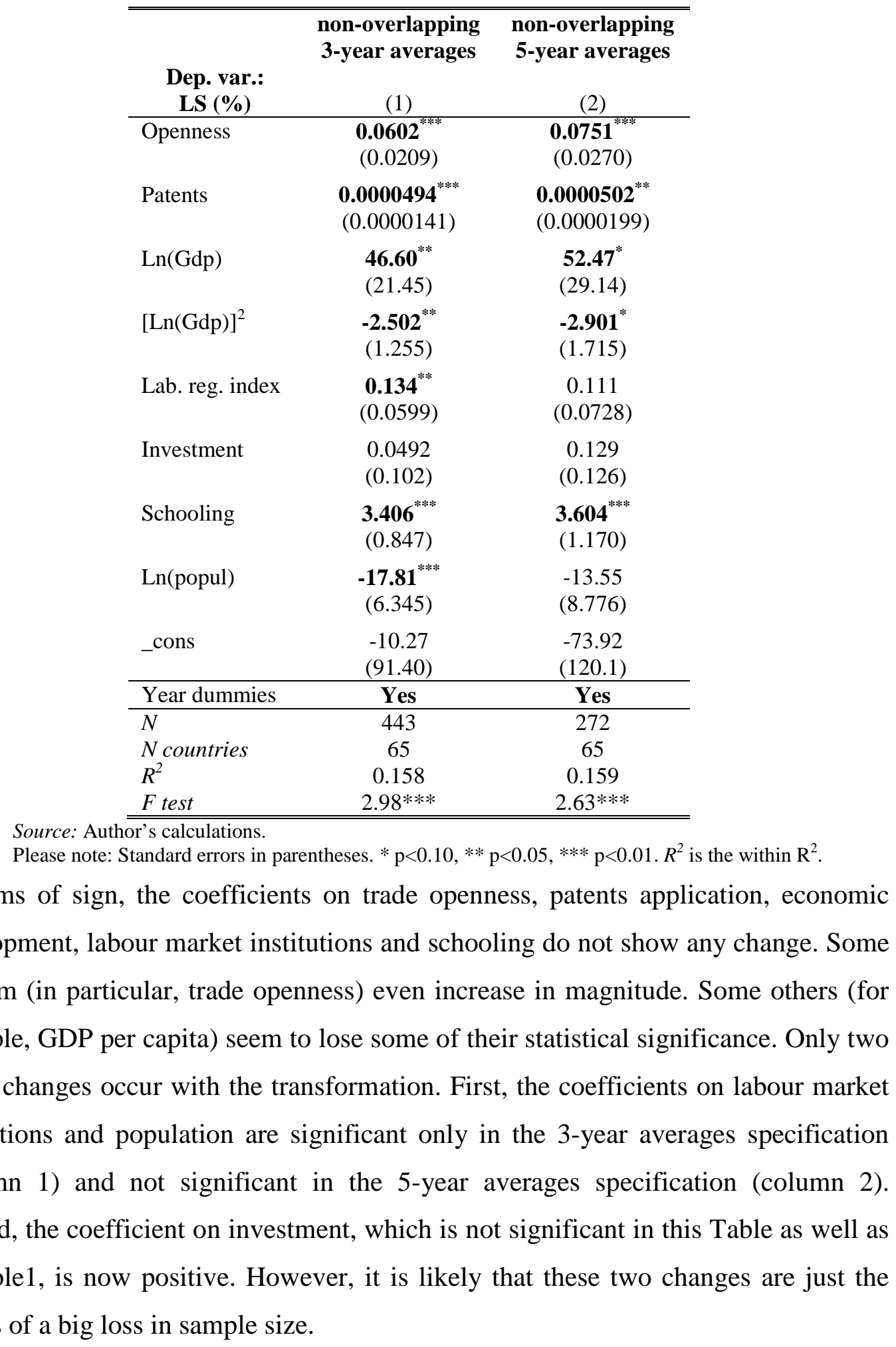

Source: Author's calculations. 


\section{The impact of trade openness and technological progress}

\subsection{International trade: choice of alternative variables}

Table4 explores alternative approaches to measuring the impact of globalisation. The PWT trade outcome variable (column 1) has been replaced with the Sachs and Warner (Sachs and Warner, 1995) dummy variable of openness (column 2). Also in this case, the relationship between trade openness and the labour share seems to be positive (the sign is positive and the coefficient is highly significant): a country's transition from non-open to open to international trade is associated to an increase of 4.2 percentage points in the labour share. In the same specification, as expected, the coefficients on labour market regulations and years of schooling are positive and significant, while the coefficients on investment and population are negative, even if not significant. A considerable change in the results concerns the coefficients on economic development and patents applications. Not only are they not significant, but they also show opposite signs compared to the results in column 1 . This can be explained by the fact that the Sachs and Warner measure of trade openness only covers the time series 1950-1992, and does not take more recent years into account. This may make it impossible to capture the quadratic relationship with GDP per capita, and also the significance of the last two decades of innovation and technological change. Moreover, considerably reduced in the regression analysis are the total number of observations (from $N=1134$ to $N=498$ ) and the total number of countries in the sample (from 65 to 35).

In column 3, the PWT trade outcome variable has been replaced with a broader index of globalisation, the 2010 KOF Index of Globalisation (Dreher, 2006). The results are considerably similar to those in column 1 . Globalisation is positively and significantly associated with the labour share (one percentage point increase in globalisation is associated to a 0.21 percentage points increase in the labour share). The coefficients on patents, labour market regulations and schooling are positive and significant, and the coefficient on population is negative and significant. GDP per capita shows the expected significant quadratic relationship and investment the expected negative relationship, but it is once again not significant.

Column 4 introduces in the specification the variable on trade restrictions (barriers, tariffs, taxes on trade and capital accounts restrictions) from the KOF Index of Globalisation, as another alternative measure of trade openness. Once again, the relationship between international trade and the labour share seems to be positive and 
significant: one percentage point increase in the index leads to a 0.11 rise in the labour share. Furthermore, the results on the other explanatory variables are perfectly consistent with what previously found.

Table4. Choice of alternative variables. International trade.

\begin{tabular}{|c|c|c|c|c|c|c|}
\hline \multirow[b]{2}{*}{$\begin{array}{c}\text { Dep. var.: } \\
\text { LS (\%) }\end{array}$} & \multirow{2}{*}{$\begin{array}{c}\text { Benchmark } \\
\text { specification } \\
\text { (1) }\end{array}$} & \multirow{2}{*}{$\begin{array}{c}\text { Sachs- } \\
\text { Warner } \\
\text { openness } \\
(2)\end{array}$} & \multirow{2}{*}{$\begin{array}{c}\text { KOF Index } \\
\text { of } \\
\text { Globalisation } \\
\text { (3) }\end{array}$} & \multirow{2}{*}{$\begin{array}{c}\text { Restrictions } \\
\text { to trade } \\
\text { (4) }\end{array}$} & \multicolumn{2}{|c|}{$\begin{array}{l}\text { Foreign Direct } \\
\text { Investments }\end{array}$} \\
\hline & & & & & (5) & (6) \\
\hline $\begin{array}{l}\text { Openness } \\
\text { (PWT) }\end{array}$ & $\begin{array}{l}\mathbf{0 . 0 4 9 7}^{\text {****}} \\
(0.0145)\end{array}$ & & & & & $\begin{array}{c}0.0152 \\
(0.0251)\end{array}$ \\
\hline $\begin{array}{l}\text { Openness } \\
(\mathrm{S}-\mathrm{W})\end{array}$ & & $\begin{array}{l}\mathbf{4 . 1 5 3}^{* * *} \\
(1.455)\end{array}$ & & & & \\
\hline KOF Index & & & $\begin{array}{l}\mathbf{0 . 2 0 8}^{* * *} \\
(0.0673)\end{array}$ & & & \\
\hline $\begin{array}{l}\text { Trade } \\
\text { Restrictions }\end{array}$ & & & & $\begin{array}{l}\mathbf{0 . 1 1 7} \\
(0.0420)\end{array}$ & & \\
\hline FDI outflow & & & & & $\begin{array}{c}0.121 \\
(0.0892)\end{array}$ & $\begin{array}{c}0.125 \\
(0.0914)\end{array}$ \\
\hline FDI inflow & & & & & $\begin{array}{l}\mathbf{- 0 . 2 0 8} \\
(0.0947)\end{array}$ & $\begin{array}{l}-\mathbf{0 . 2 2 7} \\
(0.0999)\end{array}$ \\
\hline Patents & $\begin{array}{l}\mathbf{0 . 0 0 0 0 4 1 6} \\
(0.00000888)\end{array}$ & $\begin{array}{r}-0.00000835 \\
(0.0000129)\end{array}$ & $\begin{array}{l}\mathbf{0 . 0 0 0 0 3 4 3}^{* * *} \\
(0.00000840)\end{array}$ & $\begin{array}{l}\mathbf{0 . 0 0 0 0 2 8 7}^{\text {****}} \\
(0.00000881)\end{array}$ & $\begin{array}{c}\mathbf{0 . 0 0 0 0 3 9 3}^{\text {****}} \\
(0.0000133)\end{array}$ & $\begin{array}{c}\mathbf{0 . 0 0 0 0 4 1 3}^{* * *} \\
(0.0000139)\end{array}$ \\
\hline Ln(Gdp) & $\begin{array}{l}53.61^{* * *} \\
(14.95)\end{array}$ & $\begin{array}{l}-24.26 \\
(40.49)\end{array}$ & $\begin{array}{l}\mathbf{4 1 . 8 1}^{* * *} \\
(14.38)\end{array}$ & $\begin{array}{l}\mathbf{4 6 . 7 1} \\
(14.30)\end{array}$ & $\begin{array}{l}47.97^{* * *} \\
(14.98)\end{array}$ & $\begin{array}{l}47.52^{* * *} \\
(15.28)\end{array}$ \\
\hline$[\operatorname{Ln}(\mathrm{Gdp})]^{2}$ & $\begin{array}{l}-2.795^{* * *} \\
(0.863)\end{array}$ & $\begin{array}{c}2.205 \\
(2.446)\end{array}$ & $\begin{array}{l}-2.096^{* *} \\
(0.824)\end{array}$ & $\begin{array}{l}-2.342^{* * *} \\
(0.822)\end{array}$ & $\begin{array}{l}-2.549^{* * *} \\
(0.851)\end{array}$ & $\begin{array}{l}-2.550 \\
(0.863)\end{array}$ \\
\hline Lab. reg. index & $\begin{array}{l}\mathbf{0 . 1 1 4} \\
(0.0360)\end{array}$ & $\begin{array}{c}\mathbf{0 . 1 3 2}^{* *} \\
(0.0519)\end{array}$ & $\begin{array}{l}\mathbf{0 . 0 9 3 8}^{* * *} \\
(0.0359)\end{array}$ & $\begin{array}{l}\mathbf{0 . 0 8 4 4} \\
(0.0375)\end{array}$ & $\begin{array}{c}0.0328 \\
(0.0353)\end{array}$ & $\begin{array}{c}0.0350 \\
(0.0356)\end{array}$ \\
\hline Investment & $\begin{array}{l}-0.00305 \\
(0.0616)\end{array}$ & $\begin{array}{l}-0.129 \\
(0.101)\end{array}$ & $\begin{array}{l}-0.00225 \\
(0.0621)\end{array}$ & $\begin{array}{l}-0.0281 \\
(0.0628)\end{array}$ & $\begin{array}{l}-0.0123 \\
(0.0649)\end{array}$ & $\begin{array}{l}-0.00756 \\
(0.0640)\end{array}$ \\
\hline Schooling & $\begin{array}{l}3.857^{* * *} \\
(0.529)\end{array}$ & $\begin{array}{l}3.390^{* * *} \\
(0.979)\end{array}$ & $\begin{array}{l}3.822^{* * *} \\
(0.530)\end{array}$ & $\begin{array}{l}3.949^{* * *} \\
(0.527)\end{array}$ & $\begin{array}{l}\mathbf{4 . 1 0 8}^{* * *} \\
(0.478)\end{array}$ & $\begin{array}{c}4.137^{* * *} \\
(0.480)\end{array}$ \\
\hline Ln(popul) & $\begin{array}{c}\mathbf{- 1 9 . 1 8}^{* * *} \\
(4.255)\end{array}$ & $\begin{array}{c}-1.875 \\
(10.05)\end{array}$ & $\begin{array}{c}-18.15^{* * *} \\
(4.500)\end{array}$ & $\begin{array}{c}-21.65^{* * *} \\
(4.369)\end{array}$ & $\begin{array}{l}-7.842^{*} \\
(4.196)\end{array}$ & $\begin{array}{l}-7.287^{*} \\
(4.240)\end{array}$ \\
\hline _cons & $\begin{array}{c}-37.57 \\
(61.36) \\
\end{array}$ & $\begin{array}{c}101.2 \\
(111.4) \\
\end{array}$ & $\begin{array}{c}-3.053 \\
(59.59) \\
\end{array}$ & $\begin{array}{c}8.667 \\
(59.48) \\
\end{array}$ & $\begin{array}{l}\mathbf{- 1 0 6 . 6} \\
(62.59) \\
\end{array}$ & $\begin{array}{l}\mathbf{- 1 0 8 . 7} \\
(62.76) \\
\end{array}$ \\
\hline Year dummies & Yes & Yes & Yes & Yes & Yes & Yes \\
\hline$N$ & 1134 & 498 & 1113 & 1113 & 1008 & 1008 \\
\hline$N$ of countries & 65 & 35 & 64 & 64 & 65 & 65 \\
\hline & 0.152 & 0.1896 & 0.1609 & 0.1590 & 0.1448 & 0.1453 \\
\hline$F$ test & $4.03 * * *$ & $3.04^{* * *}$ & $4.12 * * *$ & $4.23^{* * *}$ & $3.88 * * *$ & $3.85^{* * *}$ \\
\hline
\end{tabular}

Finally, columns 5 and 6 display the results on Foreign Direct Investment (FDI) outflows and inflows. In column 5 the measure of trade openness has been replaced in the specification with the two variables on FDIs. In column 6, instead, FDIs have been added to the benchmark specification as additional explanatory variables. 
As previously presented, FDI inflows and outflows generate ambiguous effects on the labour share. Higher FDI inflows may imply job creation and higher wages in the expanding industries, as well as spill-over effects in the local economy (UNCTAD, 1994). On the contrary, the coefficient on inflows in our regression is negative and statistically significant. This is puzzling, but not totally surprising, given that also Harrison (2002) finds a similar result. FDI inflows, in fact, may erode wage levels as domestic firms try to compete. Moreover, the displacements of existing firms and/or acquisitions may also lead to job losses. These results are also in line with early "dependency" theories on the impact of FDIs on host countries, according to which FDI inflows have a long-term retardant effect on economic growth in developing countries and are associated with greater income inequality (Bornschier and ChaseDunn, 1985).

The coefficient on FDI outflows, instead, is positive (but not significant): additional exports of capital equipment, intermediate goods and new product lines to foreign affiliates, as well as the need for greater management activities, in fact, may lead to a rise in both employment and wages, and therefore an increase in the labour share. Moreover, by increasing profits, foreign outsourcing may enhance productivity and accelerate innovation, depressing wages and producing a positive growth effect, which in the long run leads to an improvement in welfare (Glass \& Saggi, 2001; Grossman \& Rossi-Hansberg, 2008).

Finally, the coefficients on the other variables in the regression in columns 5 and 6 show the same signs as in column 1. Only the PWT variable of trade openness and the index of labour market regulations seem to lose their significance.

\subsection{Technological change: choice of alternative variables}

Table5 investigates alternative approaches to measuring the impact of technological change. The WDI variable on the number of patents application (column 1) has been replaced in column 2 with the WDI variable on expenditures for research and development (as a percentage of GDP). Data on R\&D expenditure, even if less biased than those on patents application, have been recorded only over the period 1996-2008, therefore the total number of observations in the regression is considerably reduced in size (from $N=1134$ to $N=512$, and in particular from an average of 17.4 time series per country to an average of 8.0 ). This may considerably affect the results. 
Table5. Choice of alternative variables. Technological change.

\begin{tabular}{|c|c|c|c|c|}
\hline \multirow{2}{*}{$\begin{array}{c}\text { Dep. var.: } \\
\text { LS (\%) }\end{array}$} & \multirow{2}{*}{$\begin{array}{c}\text { Benchmark } \\
\text { specification } \\
\text { (1) }\end{array}$} & \multirow{2}{*}{$\begin{array}{c}\text { Expenditure } \\
\text { in } \mathbf{R} \& \mathbf{D} \\
\text { (2) }\end{array}$} & \multicolumn{2}{|c|}{ Machinery capital } \\
\hline & & & (3) & (4) \\
\hline $\begin{array}{l}\text { Openness } \\
\text { (PWT) }\end{array}$ & $\begin{array}{l}\mathbf{0 . 0 4 9 7}^{\text {**** }} \\
(0.0145)\end{array}$ & $\begin{array}{l}\mathbf{0 . 0 8 8 4}^{\text {****}} \\
(0.0251)\end{array}$ & $\begin{array}{l}\mathbf{0 . 0 7 5 0}^{* * *} \\
(0.0123)\end{array}$ & $\begin{array}{l}\mathbf{0 . 0 5 2 4}^{\text {*** }} \\
(0.0140)\end{array}$ \\
\hline Patents & $\begin{array}{l}\mathbf{0 . 0 0 0 0 4 1 6}^{\text {****}} \\
(0.00000888)\end{array}$ & & & $\begin{array}{l}\mathbf{0 . 0 0 0 0 3 8 3}^{* * *} \\
(0.00000866)\end{array}$ \\
\hline R\&D exp. & & $\begin{array}{l}3.326{ }^{* *} \\
(1.352)\end{array}$ & & \\
\hline Mach. K & & & $\begin{array}{c}-1.214^{* * *} \\
(0.237)\end{array}$ & $\begin{array}{c}-\mathbf{0 . 7 2 4} \\
(0.197)\end{array}$ \\
\hline Ln(Gdp) & $\begin{array}{l}53.61^{* * *} \\
(14.95)\end{array}$ & $\begin{array}{l}111.2^{* * *} \\
(39.58)\end{array}$ & $\begin{array}{l}\mathbf{6 7 . 1 1}^{* * *} \\
(13.58)\end{array}$ & $\begin{array}{l}\mathbf{6 6 . 8 4}^{* * *} \\
(16.51)\end{array}$ \\
\hline$[\mathrm{Ln}(\mathrm{Gdp})]^{2}$ & $\begin{array}{c}-2.795^{* * *} \\
(0.863)\end{array}$ & $\begin{array}{c}-\mathbf{6 . 9 5 9} 9^{* * *} \\
(2.122)\end{array}$ & $\begin{array}{c}-3.919 * * * \\
(0.796)\end{array}$ & $\begin{array}{c}-3.541 \\
(0.955)\end{array}$ \\
\hline Lab. reg. index & $\begin{array}{l}\mathbf{0 . 1 1 4} \\
(0.0360)\end{array}$ & $\begin{array}{l}0.0789 \\
(0.146)\end{array}$ & $\begin{array}{c}0.0376 \\
(0.0371)\end{array}$ & $\begin{array}{l}\mathbf{0 . 0 8 1 0}{ }^{* *} \\
(0.0367)\end{array}$ \\
\hline Investment & $\begin{array}{c}-0.00305 \\
(0.0616)\end{array}$ & $\begin{array}{l}\mathbf{0 . 2 1 9}^{* * *} \\
(0.0828)\end{array}$ & $\begin{array}{l}\mathbf{0 . 1 8 0} \\
(0.0573)\end{array}$ & $\begin{array}{c}0.0990 \\
(0.0655)\end{array}$ \\
\hline Schooling & $\begin{array}{l}3.857^{* * *} \\
(0.529)\end{array}$ & $\begin{array}{l}2.555^{* *} \\
(1.221)\end{array}$ & $\begin{array}{l}2.967^{* * *} \\
(0.499)\end{array}$ & $\begin{array}{l}3.771^{* * *} \\
(0.521)\end{array}$ \\
\hline Ln(popul) & $\begin{array}{c}-\mathbf{1 9 . 1 8}^{* * *} \\
(4.255)\end{array}$ & $\begin{array}{c}18.65 \\
(11.50)\end{array}$ & $\begin{array}{c}-\mathbf{2 0 . 3 9} \\
(3.294)\end{array}$ & $\begin{array}{c}-22.44^{* * *} \\
(4.272)\end{array}$ \\
\hline _cons & $\begin{array}{l}-37.57 \\
(61.36) \\
\end{array}$ & $\begin{array}{l}-572.2^{* *} \\
(234.3)\end{array}$ & $\begin{array}{l}-53.48 \\
(49.70) \\
\end{array}$ & $\begin{array}{c}-62.48 \\
(62.29) \\
\end{array}$ \\
\hline Year dummies & Yes & Yes & Yes & Yes \\
\hline$N$ & 1134 & 512 & 1255 & 994 \\
\hline$N$ of countries & 65 & 64 & 58 & 52 \\
\hline$R^{2}$ & 0.152 & 0.125 & 0.128 & 0.206 \\
\hline$F$ test & $4.03 * * *$ & $5.09 * * *$ & $4.47 * * *$ & $5.27 * * *$ \\
\hline
\end{tabular}

Also in this case the effect of technology on the labour share is positive and statistically significant. One percentage point increase in the expenditures for research and development is associated to a 3.3 percentage point increase in the labour share. Also the coefficients on GDP, openness and education are statistically significant. In particular, the coefficients on per capita GDP and its squared value are double the size of the coefficients in column 1. Contrary to the benchmark specification, the coefficient on labour market institutions loses its significance, while the coefficient on investment gains it but, contrary to what expected, the relationship seems now to be positive.

The other measure of technological change we take into account is a measure of mechanisation, the share of machinery capital over total capital stock. Capturing a different aspect of technological change, less related to innovation and more related to 
the use of machineries, this variable is analysed both in substitution of the variable on patents applications (in column 3) and in addition to it (column 4).

We first analyse column 3. The coefficient on capital machinery is negative, big in magnitude and highly significant. One percentage point increase in the mechanisation of capital is associated to a 1.2 percentage point reduction in the labour share. As previously discussed, there may be two explanations for this. Firstly, machinery capital, being progressively introduced as a substitute of low-skilled labour, may contribute to an overall reduction of the demand for labour. Secondly, ongoing technological progress and mechanisation, increasing the rate of obsolescence of capital goods, may have put firms in a stronger bargaining position compared to the labour force (Ellis \& Smith, 2007). The coefficients on trade openness, economic development, education and population do not seem to be significantly affected by the additional regressor. The coefficient on labour market regulations, instead, is not any more significant, while the coefficient on investment is surprisingly positive and significant once again. This may be due to the elimination of the variable on patents applications from the specification (investment and patents applications are highly correlated, see Appendix B). In fact, when we reintroduce patents into the model (column 4), the coefficient on investment loses its significance and becomes very small in magnitude.

Results from column 4 show that both the coefficients on technological change remain highly significant when they are considered together in the specification: they most likely capture two different aspects of technological progress. The effect of technological innovation, proxied by the total number of patents applications, is positive. On the other hand, the effect of mechanisation and computerisation, proxied by the contribution of machinery capital to the total capital stock, is negative. All the other coefficients are significant and show the expected signs, including the coefficient on labour market institutions which was not significant in column 3. Only the coefficient on investment is not significant, but this is consistent with the benchmark model in column 1.

\subsection{Developed and developing countries}

Table6 reports another extension of the baseline specification. In column 1 all the explanatory variables have been interacted with a dummy for OECD countries, in order to isolate the behaviour of these countries from the rest of the world. Not 
surprisingly, when we introduce the interactions, we obtain different outcomes. As the results suggest, the coefficient on openness is positive and significant in the rest of the world and negative and significant in the OECD. An increase of one percentage point in trade openness is associated to a 0.12 percentage point increase in the labour share in the rest of the world, and a 0.11 percentage point decline in the labour share in OECD countries. Concerning technological progress, instead, the story is exactly the opposite: the coefficient is positive for OECD countries and negative for the rest of the world, although non-significant. Consequently, the effects of trade and technology on the labour share vary depending on the type of country. In OECD countries, international trade seems to depress labour while technological change seems to benefit it. The opposite, instead, happens in non-OECD countries, where trade openness seems to have a positive effect on the labour share, while technological change seems to have a negative effect. In relation to international trade, the results seem plausible (the same results were found in Diwan (2001) as well) and in accordance with the model proposed by Heckscher and Ohlin (Ohlin, 1933; Stolper \& Samuelson, 1941). Because of specialisation, international trade changes factor prices and benefits the factor used intensively in the export sector. Therefore, it negatively affects labour in developed countries, while positively affects labour in developing countries.

With reference to the effect of GDP per capita, the same quadratic relationship appears to be in place everywhere in the world. However, the slope of the curve for OECD countries seems to be less steep. Also labour market institutions and education have a positive effect on the labour share everywhere in the world. However, the coefficient on labour market institutions is never significant, while the coefficient on schooling is significant only for the interacted term. This means that it is mostly in OECD countries where an increase in years of schooling is significantly associated to an increase in labour income: it is only when the economy is developed to a certain level of income that human capital plays an important role. The puzzling result is related to investment. The coefficient for non-OECD countries is negative and not significant, while the coefficient for OECD countries is positive and significant. An increase of one percentage point in investment in OECD countries is associated to an increase of 0.24 percentage points in the labour share. 
Table6. Interaction terms with OECD dummy.

Robust FE regressions.

\begin{tabular}{|c|c|c|}
\hline $\begin{array}{c}\text { Dep. var.: } \\
\text { LS (\%) }\end{array}$ & $\begin{array}{c}\text { Interactions } \\
\text { with OECD } \\
\text { (1) }\end{array}$ & $\begin{array}{c}\text { Interactions } \\
\text { with DEV } \\
\text { (2) }\end{array}$ \\
\hline Openness & $\begin{array}{l}\mathbf{0 . 1 2 5 ^ { * * * }} \\
(0.0189)\end{array}$ & $\begin{array}{l}\mathbf{0 . 1 1 6}^{\text {*** }} \\
(0.0330)\end{array}$ \\
\hline Patents & $\begin{array}{c}-0.0000388 \\
(0.000267)\end{array}$ & $\begin{array}{c}-0.0000169 \\
(0.000393)\end{array}$ \\
\hline Ln(Gdp) & $\begin{array}{l}122.0^{* * *} \\
(28.73)\end{array}$ & $\begin{array}{c}17.45 \\
(45.69)\end{array}$ \\
\hline$[\operatorname{Ln}(\mathrm{Gdp})]^{2}$ & $\begin{array}{c}-7.482^{* * *} \\
(1.742)\end{array}$ & $\begin{array}{l}-0.993 \\
(2.755)\end{array}$ \\
\hline Lab. reg. index & $\begin{array}{l}0.0731 \\
(0.125)\end{array}$ & $\begin{array}{l}0.0653 \\
(0.126)\end{array}$ \\
\hline Investment & $\begin{array}{l}-0.0699 \\
(0.0688)\end{array}$ & $\begin{array}{c}0.0198 \\
(0.0783)\end{array}$ \\
\hline Schooling & $\begin{array}{c}0.453 \\
(1.077)\end{array}$ & $\begin{array}{l}2.353^{* *} \\
(1.066)\end{array}$ \\
\hline Ln(popul) & $\begin{array}{l}\mathbf{- 1 1 . 9 8} \\
(6.185)\end{array}$ & $\begin{array}{l}\mathbf{- 1 1 . 0 1} \\
(6.485)\end{array}$ \\
\hline Openness*interacted & $\begin{array}{l}-\mathbf{0 . 2 4 0} \\
(0.0320)\end{array}$ & $\begin{array}{c}-\mathbf{0 . 0 9 3 1} \\
(0.0353)\end{array}$ \\
\hline Patents*interacted & $\begin{array}{l}0.0000546 \\
(0.000267)\end{array}$ & $\begin{array}{l}0.0000507 \\
(0.000393)\end{array}$ \\
\hline Ln(Gdp)*interacted & $\begin{array}{l}-39.76 \\
(38.99)\end{array}$ & $\begin{array}{l}140.4^{* *} \\
(54.50)\end{array}$ \\
\hline$[\mathrm{Ln}(\mathrm{Gdp})]^{2} *_{\text {interacted }}$ & $\begin{array}{c}3.338 \\
(2.257)\end{array}$ & $\begin{array}{l}-7.471^{* *} \\
(3.212)\end{array}$ \\
\hline Lab. reg. index*interacted & $\begin{array}{c}0.000295 \\
(0.130)\end{array}$ & $\begin{array}{l}0.0756 \\
(0.132)\end{array}$ \\
\hline Investment*interacted & $\begin{array}{l}\mathbf{0 . 3 0 6}^{* * *} \\
(0.106)\end{array}$ & $\begin{array}{l}-0.157 \\
(0.121)\end{array}$ \\
\hline Schooling*interacted & $\begin{array}{l}\mathbf{4 . 0 2 6}^{* * *} \\
(1.106)\end{array}$ & $\begin{array}{l}2.495^{* *} \\
(1.149)\end{array}$ \\
\hline Ln(popul)*interacted & $\begin{array}{l}-9.727 \\
(8.241)\end{array}$ & $\begin{array}{l}17.64^{*} \\
(9.399)\end{array}$ \\
\hline _cons & $\begin{array}{c}-237.8^{* * *} \\
(70.88)\end{array}$ & $\begin{array}{c}-400.7^{* * *} \\
(97.45)\end{array}$ \\
\hline Year dummies & Yes & Yes \\
\hline$N$ & 1134 & 1134 \\
\hline$N$ of countries & 65 & 65 \\
\hline$R^{2}$ & 0.251 & 0.206 \\
\hline$F$ test & $8.54 * * *$ & $6.99 * * *$ \\
\hline
\end{tabular}

Please note: Standard errors in parentheses. ${ }^{*} \mathrm{p}<0.10,{ }^{* *} \mathrm{p}<0.05$, ${ }^{* * *} \mathrm{p}<0.01 . R^{2}$ is the within $\mathrm{R}^{2}$. 
Column 2 displays a very similar analysis, but instead of using a dummy for OECD countries, we use a better proxy for development: $D E V=1$ if the country is a highincome country, $D E V=0$ if the country is a low- and middle- income country ${ }^{15}$.

Compared to the previous results, the Heckscher-Ohlin story does not seem to hold entirely. One percentage point increase in trade openness is here associated to a 0.12 percentage point increase in the labour share in developing countries, and only a 0.02 percentage point increase in developed countries. The effect of trade openness is therefore positive all over the world; however, it is much stronger in developing countries. It is necessary to mention here, though, that there are almost no low-income countries in this analysis, therefore the category “developing countries” includes only low-middle and high-middle income economies. Consequently, following Melvin (1968)'s 'cones of diversification' theory, we may think that some of the middle income developing economies in the dataset are capital-abundant countries of the South (while some others are labour-abundant countries of the North), and behave in a very different way compared to what is predicted by standard trade theory.

The results on patents applications are similar to those obtained in column 1 . The relationship seems to be negative in developing countries and positive in industrialised countries. However, none of the coefficients is statistically significant. Also the quadratic relationship with GDP per capita seems to hold. However, in this case, the curve is much steeper in developed countries. Once again, the coefficients on labour market institutions and education are positive. Moreover, education is strongly significant everywhere. The unexpected result, again, is related to investment. The coefficient for developing countries is positive, while the coefficient for industrialised countries is negative and significant: one percentage point increase in investment is associated to 0.02 percentage point increase in the labour share in developing countries and 0.14 percentage point reduction in developed countries.

\section{Instrumental variable estimation}

A possible concern with the accuracy of the estimations is the potential for endogeneity, in particular in relation with the variables of per capita income and labour market institutions.

\footnotetext{
${ }^{15}$ This categorisation follows the World Bank income classification.
} 
Firstly, concerning per capita income, reverse causation may be possible: higher labour share, which means higher wages and higher levels of employment given the same level of income, may be associated to an increase in consumption and consequently in income. Moreover, we know from the literature that a change in functional income distribution affects the flow of income between groups of different wealth levels (Atkinson, 2000). Because labour is more equally distributed than capital, an increase in the labour share of income may positively affect personal income distribution, reducing inequality. And a variation in personal income distribution may influence overall economic growth (Alesina \& Perotti, 1996; Forbes, 2000; Galor \& Zeira, 1993; Persson \& Tabellini, 1994).

Secondly, in relation to labour market institutions, reverse causality or common third factors may bias the relationship: countries with higher labour share may also be more likely to face better regulatory environments.

In addition to these two potential endogenous variables, other regressors may be also endogenous. For example, the literature suggests reverse causality may bias the effect of trade openness if we consider mechanisms such as off-shoring or labour immigration (IMF, 2007).

When valid instruments exist, the instrumental variable (IV) approach is the best way to provide consistent estimates. However, weak instruments are also a particular concern, since one of the side effects of IV estimation is the loss of efficiency. In order to minimise this loss, the instrumental variable needs to be exogenous and relevant. Unfortunately, no external instrument has been found ${ }^{16}$ to fit the requirements and correct the identified bias. Thus, we need to resort to internal instruments.

IV estimation has been performed instrumenting all the explanatory variables (except time dummies) with their lagged values. The rationale is that, although current values of the regressors may be endogenous, it is unlikely that past values are subject to the same problem. Not only are lags intuitively appealing, but they are also simple to implement and do not require additional data. However, while using lagged values of the regressors as instruments can help deal with problems of reverse causality, it does not address biases arising due to measurement errors or omitted variables. Moreover,

\footnotetext{
${ }^{16}$ To be used in a fixed effects context, where all time-invariant variables are dropped from the estimation.
} 
they may be problematic in the presence of serial correlation. It is necessary to analyse the results keeping these limitations into consideration.

Table7 displays the results for IV estimation on the benchmark specification by a twostage least-squares (2SLS) regression. One-, two-, and three-year lags have been used as instruments (see Appendix I for the results for all the specifications with one-year lag instrumentation) ${ }^{17}$.

Table7. Instrumental variable estimation. Benchmark specification

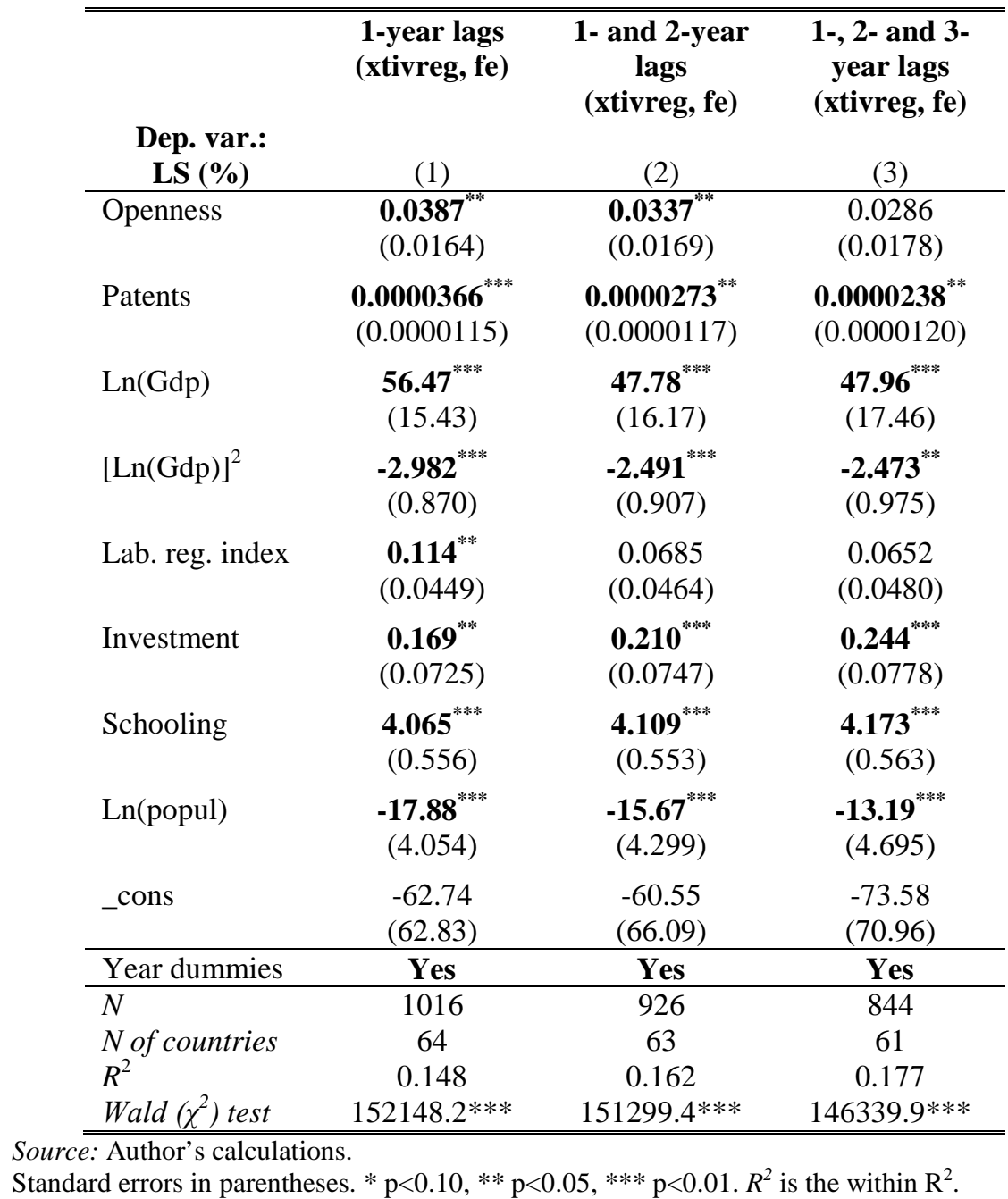

Column 1 shows instrumentations with one-year lags. Comparing the IV results with those obtained in the standard fixed effects estimation (Table1), the signs, magnitudes and significances of the coefficients have remained very similar, with the exception of the coefficient on investment, which has changed sign and is many times larger in

\footnotetext{
${ }^{17}$ Stata's command xtivreg, $f e$ implements a two-stage least-squares within estimation which fits fixed effects in the case of endogeneity. It does not provide an option to produce robust standard errors, so we have reported here the default standard errors. The user-written command xtivreg2 (Schaffer, 2010) has been used for heteroskedasticity-robust estimates, see Appendix J. The results obtained are very similar.
} 
absolute value. IV estimation does not seem to lead to a substantial loss in the efficiency of the estimator. When we add two-year lags (column 2), the coefficient on labour market regulations loses significance and becomes considerably smaller in size. The same happens to the coefficient on trade openness with three-year lags (column 3). The problem here is a considerable reduction in sample size with the increase in the number of lags $(N=1016$ in column $1, N=926$ in column 2, and $N=$ 844 in column 3). Ultimately, we test for the presence of endogeneity, using Davidson and MacKinnon's (1993) test of exogeneity, which accommodates unbalanced panels. The rejection of the null indicates that IV techniques are required and the IV fixed effects estimator should be employed.

\section{Concluding remarks}

With the use of an extensive dataset of the labour share, covering 89 countries and all or part of the period 1970-2009, this paper studies the relationships between the labour share and measures of international trade and technological change.

In accordance with recent literature, the share of labour in national income varies considerably both over time and across countries. Specifically, there seems to be a general reduction in the labour share around the world over the last few decades.

In response to recent literature, evoking trade and technology as possible determinants of these trends, this study tests for the impact of different measures of globalisation and technological progress on the labour share. Robust across different specifications, the results suggest that trade and technology do play a role on functional distribution of income.

In contradiction with recent studies, trade openness seems to have a positive and significant effect on the labour share, especially in developing countries, enhancing income, employment and productivity growth. On the contrary, FDI inflows are negative drivers of labour, eroding wage and employment levels among the domestic firms. Moreover, while technological innovation appears to be positively and significantly related to the labour share, technological mechanisation is negatively associated. Finally, other factors also matter: the level of economic development, education, and the strength of the regulations in the labour market. These results open up new discussions on the determinants of income shares. 


\section{References}

Acemoglu, D. (2002). Technical Change, Inequality, and the Labor Market. Journal of Economic Literature, $X L, 7-72$.

ADB. (2005). Labor Markets in Asia: Promoting Full, Productive, and Decent Employment. In.

Alesina, A., \& Perotti, R. (1996). Income Distribution, Political Instability and Investment. European Economic Review, 40, 1203-1228.

Arpaia, A., Pérez, E., \& Pichelmann, K. (2009). Understanding Labour Income Share Dynamics in Europe. European Economy. Economic Papers, 379.

Atkinson, A. B. (2000). The Changing Distribution of Income: Evidence and Explanations. German Economic Review, 1, 3-18.

Atkinson, A. B. (2009). Factor shares: the principal problem of political economy? Oxford Review of Economic Policy, 25, 3-16.

Azmat, G., Manning, A., \& Reenen, J. V. (2011). Privatization and the Decline of Labour's Share: International Evidence from Network Industries. Economica, $X X$, 1-23.

Baltagi, B. H. (2005). Econometric Analysis of Panel Data. Chichester, United Kingdom: John Wiley \& Sons Ltd.

Barrell, R., \& Pain, N. (1997). Foreign Direct Investment, Technological Change and Economic Growth Within Europe. The Economic Journal, 107, 1770-1786.

Barro, R. J. (1991). Economic Growth in a Cross Section of Countries. The Quarterly Journal of Economics, 106, 407-443.

Barro, R. J., \& Lee, J.-W. (2010). A New Data Set of Educational Attainment in the World, 1950-2010. NBER Working Paper No. 15902.

Barro, R. J., \& Sala-i-Martin, X. (2004). Economic Growth. Cambridge, MA: MIT Press.

Baum, C. F., \& Stillman, S. (2003). DMEXOGXT: Stata module to test consistency of OLS vs XT-IV estimates. Available at: http://fmwww.bc.edu/repec/bocode/d/dmexogxt.ado. In.

Bentolila, S., \& Saint-Paul, G. (2003). Explaining Movements in the Labor Share. Contributions to Macroeconomics, 3.

Bergh, A., \& Nilsson, T. (2010). Do Economic Liberalization and Globalization Increase Income Inequality? European Journal of Political Economy, 26, 488-505.

Berman, E., \& Machin, S. (2000). Skill-Biased Technology Transfer Around the World. Oxford Review of Economic Policy, 16, 12-22.

Bernanke, B. S., \& Gürkaynak, R. S. (2001). Is Growth Exogenous? Taking Mankiw, Romer, and Weil Seriously. NBER Macroeconomics Annual, 16.

Besley, T., \& Burgess, R. (2004). Can Labor Regulation Hinder Economic Performance? Evidence from India. The Quarterly Journal of Economics, 119, 91-134.

Bhagwati, J. (1994). Free Trade: Old and New Challenges. The Economic Journal, 104, 231246.

Blecker, R. A. (2003). International Economics. In J. E. King (Ed.), The Elgar Companion to Post Keynesian Economics. Cheltenham: Edward Elgar Publishing Limited.

Bond, S., \& Harding, R. (2011). \$740bn pay gap threat to US recovery. In Financial Times (Vol. 15 Dec 2011, pp. 1).

Bornschier, V., \& Chase-Dunn, C. (1985). Transnational Corporations and Underdevelopment. New York: Praeger.

Botero, J. C., Djankov, S., Porta, R. L., Lopez-de-Silanes, F., \& Schleifer, A. (2004). The Regulation of Labor. The Quarterly Journal of Economics, 119, 1339-1382.

Bound, J., Cummins, C., Griliches, Z., Hall, B. H., \& Jaffe, A. B. (1984). Who Does R\&D and Who Patents? In Z. Griliches (Ed.), $R \& D$, Patents and Productivity: University of Chicago Press.

Burtless, G. (1995). International Trade and the Rise in Earnings Inequality. Journal of Economic Literature, XXXIII, 800-816. 
Campos, N. F., \& Nugent, J. B. (2011). The Dynamics of the Regulation of Labor in Developing and Developed Countries since 1960. In http://www.naurocampos.net/papers/LAMRIG.html.

Cline, W. R. (1997). Trade and Income Distribution: Institute for International Economics.

Cohen, D., \& Soto, M. Growth and Human Capital: Good Data, Good Results. Journal of Economic Growth, 12, 51-76.

Daudey, E., \& Garcia-Penalosa, C. (2007). The Personal and the Factor Distributions of Income in a Cross-Section of Countries. Journal of Development Studies, 43, 812829.

Daudey, E., \& Garcia-Peñalosa, C. (2007). The Personal and the Factor Distribution of Income in a Cross-Section of Countries. Journal of Development Studies, 43, 812829.

Davidson, R., \& MacKinnon, J. G. (1993). Estimation and Inference in Econometrics. New York: Oxford University Press.

Davis, D. R. (1996). Trade Liberalization and Income Distribution. NBER Working Papers, 5693.

Dinopoulos, E., \& Segerstrom, P. (1999). A Schumpeterian Model of Protection and Relative Wages The American Economic Review, 89, 450-472.

Diwan, I. (2001). Debt as Sweat: Labor, financial crises, and the globalization of capital. In. Washington DC: The World Bank.

Dollar, D., \& Kraay, A. (2001). Trade, Growth and Poverty. World Bank Policy Research Working Paper, 2615.

Dougherty, S. (2008). Labour Regulation and Employment Dynamics at the State Level in India. OECD Economics Department Working Papers, 624.

Dreher, A. (2006). Does Globalization Affect Growth? Evidence from a new Index of Globalization. Applied Economics, 38, 1091-1110.

Dreher, A., \& Gaston, N. (2008). Has Globalisation Increased Inequality? Review of International Economics, 16, 516-536.

Dreher, A., Gaston, N., \& Martens, P. (2008). Measuring Globalisation. Gauging its Consequences. New York: Springer.

EC. (2007). The Labour Income Share in the European Union. Employment in Europe 2007, Directorate-General for Employment Social Affairs and Equal Opportunities, Brussels.

Ellis, L., \& Smith, K. (2007). The global upward trend in the profit share. BIS Working Papers, n. 231.

Feenstra, R. C., \& Hanson, G. H. (1996). Globalization, Outsourcing, and Wage Inequality. The American Economic Review, 86, 240-245.

Forbes, K. J. (2000). A Reassessment of the Relationship between Inequality and Growth. The American Economic Review, 90, 869-887.

Forteza, A., \& Rama, M. (2006). Labor Market 'Rigidity' and the Success of Economic Reforms Across More Than 100 Countries. Journal of Economic Policy Reform, 9, 75-105.

Frankel, J. A., \& Romer, D. (1999). Does Trade Cause Growth? The American Economic Review, 89.

Freeman, R. B. (2003). Trade Wars: The Exaggerated Impact of Trade in Economic Debate. NBER Working Paper, No. 10000.

Galor, O., \& Zeira, J. (1993). Income Distribution and Macroeconomics. The Review of Economic Studies, 60, 35-52.

Ghose, A. K. (2000). Trade Liberalization and Manufacturing Employment. ILO Employment Paper 2000/3.

Ghose, A. K. (2003). Jobs and Incomes in a Globalizing World. Geneva: International Labour Office.

Glass, A. J., \& Saggi, K. (2001). Innovation and wage effects of international outsourcing. European Economic Review, 45, 67-86. 
Glyn, A. (2009). Functional Distribution and Inequality. In W. Salverda, B. Nolvan \& T. M. Smeeding (Eds.), Economic Inequality. Oxford: Oxford University Press.

Gollin, D. (2002). Getting Income Shares Right. The Journal of Political Economy, 110, 458474.

Greene, W. H. (2008). Econometric Analysis. Upper Saddle River, NJ: Prentice--Hall.

Griliches, Z. (1990). Patent Statistics as Economic Indicators: a Survey. Journal of Economic Literature, 28, 1661-1707.

Grossman, G. M., \& Rossi-Hansberg, E. (2008). Trading Tasks: a Simple Theory of Offshoring. The American Economic Review, 98, 1978-1997.

Guscina, A. (2006). Effects of Globalization on Labor's Share in National Income. In IMF Working Paper (Vol. 06/294): IMF.

Harrison, A. (2002). Has Globalization Eroded Labor's Share? Some Cross-Country Evidence. In UC Berkeley and NBER.

Harrison, A., McLaren, J., \& McMillan, M. (2011). Recent Perspectives on Trade and Inequality. Annual Review of Economics, 3, 261-289.

Hartwig, J. (2006). On spurious differences in growth performance and on the misuse of National Accounts data for governance purposes. Review of International Political Economy, 13, 535-558.

Hessami, Z. (2011). Globalization's winners and losers. Evidence from life satisfaction data, 1975-2001. Economic Letters, 112, 250-253.

Heston, A., Summers, R., \& Aten, B. (2006). Penn World Table Version 6.2. Center for International Comparisons of Production, Income and Prices at the University of Pennsylvania, September 2006.

Heston, A., Summers, R., \& Aten, B. (2011). Penn World Table Version 7.0. In: Center for International Comparisons of Production, Income and Prices at the University of Pennsylvania, May 2011.

Hsiao, C. (2003). Analysis of Panel Data. Cambridge, United Kingdom: Cambridge University Press.

ILO. (2008). Income Inequalities in the Age of Financial Globalization. In World of Work Report 2008. Geneva: International Institute for Labour Studies.

IMF. (2001). World Economic Outlook. The Information Technology Revolution. World Economic and Financial Surveys.

IMF. (2007). The Globalization of Labor (Chapter 5). In World Economic Outlook: Spillovers and Cycles in the Global Economy Washington.

Jaumotte, F., \& Tytell, I. (2007). How Has The Globalization of Labor Affected the Labor Income Share in Advanced Countries? IMF Working Paper, WP/07/298.

Jayadev, A. (2007). Capital account openness and the labour share of income. Cambridge Journal of Economics, 31, 423-443.

Kaldor, N. (1955-1956). Alternative Theories of Distribution. The Review of Economic Studies, 23, 83-100.

Kalecki, M. (1938). The Determinants of Distribution of the National Income. Econometrica, 6, 97-112.

Knowles, S. (2001). Are the Penn World Tables data on government consumption and investment being misused? Economic Letters, 71, 293-298.

Kravis, I. B. (1959). Relative Income Shares in Fact and Theory. The American Economic Review, 49, 917-949.

Krueger, A. B. (1999). Measuring Labor's Share. The American Economic Review, 89, 45-51.

Krugman, P. R. (2008). Trade and Wages, Reconsidered. Brookings Papers on Economic Activity, 39, 103-154.

Kuznets, S. (1955). Economic Growth and Income Inequality. The American Economic Review, 45, 1-28.

Lawless, M., \& Whelan, K. (2011). Understanding the Dynamics of Labor Shares and Inflation. Journal of Macroeconomics, 33, 121-136.

Lawrence, R. Z. (2008). Blue-Collar Blues: Is Trade to Blame for Rising US Income Inequality? Washington: Peterson Institute for International Economics. 
Leamer, E. E. (1987). Paths of Development in the Three-Factor, $n$-Good General Equilibrium Model. Journal of Political Economy, 95, 961-999.

Lewer, J. J., \& Berg, H. V. d. (2003). How Large Is International Trade's Effect on Economic Growth? Journal of Economic Surveys, 17, 363-396.

Lewis, W. A. (1955). Theory of Economic Growth.

Lübker, M. (2007). Labour Shares. In P. I. Department (Ed.), Technical Brief No. 1. Geneva: ILO.

Luo, C., \& Zhang, J. (2010). Declining Labor Share: Is China’s Case Different? China \& World Economy, 18, 1-18.

Maarek, P. (2010). Labor share, Informal sector and Development. GREQAM Working Paper.

Melvin, J. R. (1968). Production and Trade with Two Factors and Three Goods. The American Economic Review, 58, 1249-1268.

Meschi, E., \& Vivarelli, M. (2009). Trade and Income Inequality in Developing Countries. World Development, 37, 287-302.

Nickell, S., \& Layard, R. (1999). Labor market institutions and economic performance. In O. Ashenfelter \& D. Card (Eds.), Handbook of Labor Economics (Vol. 3, pp. 30293084): Elsevier.

Ohlin, B. (1933). Interregional and International Trade. Cambridge: Harvard University Press.

Ortega, D., \& Rodriguez, F. (2006). Are Capital Shares Higher in Poor Countries? In Working Paper (Vol. 2006-023): Wesleyan Economics.

Pakes, A., \& Griliches, Z. (1984). Patents, R\&D and the Stock Market Rate of Return: A Summary of Some Empirical Results. In Z. Griliches (Ed.), R\&D, Patents and Productivity: University of Chicago Press.

Pasinetti, L. L. (1962). Rate of Profit and Income Distribution in Relation to the Rate of Economic Growth. The Review of Economic Studies, 29, 267-279.

Persson, T., \& Tabellini, G. (1994). Is Inequality Harmful for Growth? The American Economic Review, 84, 600-621.

Rama, M. (2003). Globalization and Workers in Developing Countries. Policy Research Working Paper Series 2958, The World Bank.

Rama, M., \& Artecona, R. (2002). A Database of Labor Market Indicators across Countries. In Washington: World Bank, Development Research Group.

Richardson, J. D. (1995). Income Inequality and Trade: How to Think, What to Conclude. Journal of Economic Perspectives, 9, 33-55.

Robbins, D. J. (1996). HOS Hits Facts: Facts Win; Evidence on Trade and Wages in the Developing World. Development Discussion Papers. Harvard Institute for International Development, 557.

Rodrik, D. (1997). Has Globalization Gone Too Far? Washington: Institute for International Economics.

Sachs, J. D., \& Warner, A. (1995). Economic Reform and the Process of Global Integration. Brookings Papers on Economic Activity, 1, 1-118.

Samuelson, P. A. (1948). International Trade and the Equalisation of Factor Prices. The Economic Journal, 58, 163-184.

Schaffer, M. E. (2010). XTIVREG2: Stata module to perform extended IV/2SLS, GMM and AC/HAC, LIML and k-class regression for panel data models. Available at: http://fmwww.bc.edu/repec/bocode/x/xtivreg2.ado. In.

Schmookler, J. (1966). Invention and Economic Growth: Harvard University Press.

Sen, K. (2001). Globalisation and Labour Market Outcomes in the South: a critical survey. Globalisation, Production and Poverty Discussion Paper, 1.

Slaughter, M. (1999). Globalization and Wages: A Tale of Two Perspectives. In: Centre for Research on Globalisation and Labour Markets, School of Economics,

University of Nottingham.

Smeeding, T. M., \& Thompson, J. (2010). Inequality in the Distribution of Income from Labour and Income from Capital over the Recession. 31st General Conference of The 
International Association for Research in Income and Wealth, St. Gallen, Switzerland, August 22-28, 2010.

Stolper, W. F., \& Samuelson, P. A. (1941). Protection and Real Wages. The Review of Economic Studies, 9, 58-73.

Summers, R., \& Heston, A. (1988). A New Set of International Comparisons of Real Product and Price Levels Estimates for 130 countries, 1950-1985. Review of Income and Wealth, 34, 1-25.

Summers, R., \& Heston, A. (1991). The Penn World Table (Mark 5): an expanded set of international comparisons, 1950-1988. Quarterly Journal of Economics, 106, 327368.

UNCTAD. (1994). World Investment Report 1994. Transnational Corporations, Employment and the Workplace.

White, H. (1980). A Heteroskedasticity-Consistent Covariance Matrix Estimator and a Direct Test for Heteroskedasticity. Econometrica, 48, 817-838.

Wood, A. (1994). North-South Trade, Employment and Inequality: Changing Fortunes in a Skilled-Driven World. Oxford: Clarendon Press.

Wood, A. (1995). How Trade Hurt Unskilled Workers. Journal of Economic Perspectives, 9, $57-80$.

Wood, A. (2002). Could Africa Be Like America? In Annual Bank Conference on Development Economics. Washington: World Bank.

Wood, A., \& Ridao-Cano, C. (1999). Skill, Trade and International Inequality. Oxford Economic Papers, 51, 89-119. 
Appendix A

Description of the data.

\begin{tabular}{|c|c|c|}
\hline Variable name & Variable Description & Source \\
\hline Labour share & $\begin{array}{l}\text { It imputes average employees' compensation to all the self-employed except employers. } \\
\text { Total compensation of employees in the unadjusted labour share (ratio of the total } \\
\text { compensation of employees to the gross domestic product net of indirect taxes and } \\
\text { consumption of fixed capital) is multiplied by the ratio of the total workforce to the number } \\
\text { of employees. The UN National Account Statistics provide yearly data on main national } \\
\text { aggregates, collected using the System of National Accounts } 1993 \text { (then updated into the } \\
\text { System of National Accounts } 2008)^{18} \text {. They are maintained and updated on the basis of } \\
\text { annual collections of official national accounts statistics, and supplemented by estimates }{ }^{19} \\
\text { for those years and countries with incomplete or inconsistent information. } \\
\text { The ILO Yearbooks of Labour Statistics are the most fundamental publications of statistical } \\
\text { reference on labour questions. Their country profiles provide statistics on the composition of } \\
\text { total employment for nearly } 200 \text { countries and territories from } 1969 \text { to } 2008 \text {. Based on the } \\
\text { International Classification of Status in Employment ICSE-1993, they classify the } \\
\text { workforce into: 1.Employees; 2.Employers; 3.Own-account workers; 4.Members of } \\
\text { producers' cooperatives; 5.Contributing family workers; } 6 \text {.Workers not classifiable by } \\
\text { status. }\end{array}$ & $\begin{array}{l}\text { United Nations } \\
\text { National Accounts } \\
\text { Statistics }{ }^{20} \text {, ILO } \\
\text { Yearbooks of Labour } \\
\text { Statistics }{ }^{21}\end{array}$ \\
\hline Openness (PWT) & $\begin{array}{l}\text { Total trade (exports + imports) as a percentage of real GDP (PPP-converted GDP at } 2005 \\
\text { constant prices). The Penn World Table dataset has been extensively used in the literature } \\
\text { for most of the empirical growth research since the mid 1980s (Knowles, 2001). }\end{array}$ & $\begin{array}{l}\text { Penn World Table } \\
7.0^{22} \\
\text { (Heston, et al., 2011; } \\
\text { Summers \& Heston, } \\
\text { 1988, 1991) }\end{array}$ \\
\hline Openness (S-W) & $\begin{array}{l}\text { Dataset which covers more than } 100 \text { countries for some or all the years } 1950-1992 \text {. } \\
\text { OPEN = } 0 \text { for a closed economy, } 1 \text { for an open economy. Indicator constructed using the } \\
\text { following variables: black market premium for foreign exchange, marketing board for } \\
\text { commodity exports distortions, socialist nature of the economy, and quotas on imports of } \\
\text { intermediates and capital goods. Firstly, the four variables were all transformed into dummy } \\
\text { variables. Secondly, if a country scored a } 1 \text { on any of the four dummies, the variable OPEN } \\
\text { would be set to be equal to } 0 \text {, otherwise } 1 \text {. }\end{array}$ & $\begin{array}{l}\text { Sachs \& Warner, } \\
1995^{23}\end{array}$ \\
\hline KOF index & $\begin{array}{l}\text { KOF Index of Globalisation. Index ranging from } 0 \text { to } 100 \text {, covering three main dimensions } \\
\text { of globalisation: economic integration, social integration and political integration, with data } \\
\text { for } 123 \text { countries in } 1970-2000 \text {. }\end{array}$ & $\begin{array}{l}\text { Dreher, 2006; Dreher, } \\
\text { Gaston \& Martens, } \\
2008^{24}\end{array}$ \\
\hline $\begin{array}{l}\text { Restrictions on } \\
\text { trade }\end{array}$ & $\begin{array}{l}\text { Sub-index of the KOF Index of Globalisation, part of the economic globalisation dimension } \\
\text { of measurement. Index ranging from } 0 \text { to 100, constructed using: import barriers, tariff rates, } \\
\text { taxes on trade and capital controls, etc. It allocates higher ratings to countries that do not } \\
\text { impose tariffs, duties, etc. }\end{array}$ & $\begin{array}{l}\text { Dreher, 2006; Dreher, } \\
\text { Gaston \& Martens, } \\
2008\end{array}$ \\
\hline FDI inflows & $\begin{array}{l}\text { Net inflows of Foreign Direct Investments, as a percentage of GDP, with observations from } \\
1970 \text { to } 2009 \text {. Given the presence of a few gaps in the data, the missing data points }(0.2 \% \text { of } \\
\text { the data on FDI inflows) have been estimated using linear interpolation. }\end{array}$ & $\begin{array}{l}\text { World Development } \\
\text { Indicators, The World } \\
\text { Bank }^{25}\end{array}$ \\
\hline FDI outflows & $\begin{array}{l}\text { Net outflows of Foreign Direct Investments, as a percentage of GDP, with observations } \\
\text { from } 1960 \text { to } 2009 \text {. Given the presence of a few gaps in the data, the missing data points } \\
(0.7 \% \text { of the data on FDI inflows) have been estimated using linear interpolation. }\end{array}$ & $\begin{array}{l}\text { World Development } \\
\text { Indicators, The World } \\
\text { Bank }\end{array}$ \\
\hline Population & Total population (in thousands). & $\begin{array}{l}\text { United Nations, } \\
\text { Department of } \\
\text { Economic and Social } \\
\text { Affairs, Population } \\
\text { Division, Population } \\
\text { Estimates and } \\
\text { Projections Section }^{26}\end{array}$ \\
\hline Patents & $\begin{array}{l}\text { Patent applications are worldwide patent applications filed through the Patent Cooperation } \\
\text { Treaty procedure or with a national patent office for exclusive rights for an invention (a } \\
\text { product or process that provides a new way of doing something or offers a new technical } \\
\text { solution to a problem). WDI provide yearly data over the period } 1960-2009 \text {. It is impossible } \\
\text { to interpolate the data when missing, given that there is no information on whether missing } \\
\text { information correspond to "zero" patent applications, or missing data. }\end{array}$ & $\begin{array}{l}\text { World Development } \\
\text { Indicators, The World } \\
\text { Bank }\end{array}$ \\
\hline R\&D expenditure & $\begin{array}{l}\text { Expenditures for research and development are current and capital expenditures (both public } \\
\text { and private) on creative work undertaken systematically to increase knowledge and the use }\end{array}$ & $\begin{array}{l}\text { World Development } \\
\text { Indicators, The World }\end{array}$ \\
\hline
\end{tabular}

${ }^{18}$ The 'System of National Accounts 1993' was adopted by the UN Statistical Commission in 1993 as

the international standard for compilation of national accounts statistics.

${ }^{19}$ Computed on the basis of surveys of enterprises or establishments and government accounts.

${ }^{20}$ Available at: http://data.un.org/.

${ }^{21}$ Available at: http://laborsta.ilo.org/.

${ }^{22}$ Available at: http://pwt.econ.upenn.edu/.

${ }^{23}$ Available at: http://www.cid.harvard.edu/ciddata/ciddata.html.

${ }^{24}$ Available at: http://globalization.kof.ethz.ch/.

${ }^{25}$ Available at: http://data.worldbank.org/data-catalog/world-development-indicators.

${ }^{26}$ Available at: http://esa.un.org/unpd/wpp/. 
of knowledge for new applications. WDI provide yearly data over the period 1996-2008. There are a few gaps in the data. The missing data points $(9.5 \%$ of the data) have been estimated using linear interpolation, supported by the fact that the variation of $R \& D$ expenditures from one year to the other is always very low and the trend of the data over time appears to be linear in most of the cases.

Machinery K $\quad$ Machinery and equipment capital (as a percentage of the overall capital stock).

Penn World Table 6.2

(Heston, et al., 2011;

Summers \& Heston, 1988, 1991)

GDP per capita $\quad$ PPP-converted GDP per capita at 2005 constant prices (real GDP is derived using the Laspeyres index, which measures the change of price in identical 'baskets' of goods and services. The weights are related to the relative importance of the data in the index and determined in the base year). The use of PPP-adjusted GDP, which is standard practice in the literature, allows capturing for differences in the standards of living across countries, and it is not influenced by exchange rate fluctuations.

Lab. Reg. index De jure index on the rigidity of employment regulations covering approximately 100 countries, measured as 5-year averages ranging from 1950-1954 to 2000-2004. The index was constructed using two principal sources: the index of labour market rigidity developed by Botero et al (2004) for 85 countries in the year 1997; and NATLEX, a comprehensive database of labour laws maintained by the International Labour Organization. The law provisions were used to construct 36 individual components for each country in the late 1990s, according to a coding scheme identified in Botero et al (2004). The individual components, most of which scored on a 0-1 basis, were averaged into four sub-indexes (alternative employment contracts, costs of increasing hours worked, costs of firing workers, dismissal procedures), and then aggregated, with equal weighting, into a single index. The index was then compared to the values in Botero et al (2004), and then extended for a greater number of countries and for additional periods. Finally, the measures were adjusted using other regional- and country-specific sources.

The index has been rescaled ranging from 0 to 100 , and consequently yearly observations have been estimated attributing the average value of the 5-year interval to each of the five year observations. This operation is motivated by the need of matching these data with our annual observations on the labour share and justified by the fact that yearly variation in the institutional index is generally relatively low. Because we only possess average data on intervals of time and not on specific years, we cannot know exactly when the laws have changed, and therefore we attribute the same value to all the 5 years. However, as a robustness check, an alternative method has been used for the estimation of yearly data. The average value of the 5-year interval has been attributed to the year at the centre of the interval (for example, year 1952 in the interval 1950-1954), and the remaining missing data points have been estimated with linear interpolation. The two variables are highly and significantly correlated (being their coefficient of correlation equal to 0.997 and $p=0.0000$ ). This means that the institutional variable does not change abruptly over time, we can fill the gaps with yearly data without altering the measure, and the technique chosen will not affect the results in a significant way.

Investment Investment share of PPP-adjusted GDP per capita at 2005 constant prices.

Penn World Table 7.0

(Heston, et al., 2011;

Summers \& Heston, 1988, 1991)

\section{Campos and Nugent,} 2011

Penn World Table 7.0

(Heston, et al., 2011;

Summers \& Heston, 1988, 1991)

Schooling Average schooling years in the total population aged 25 or over. The dataset provides educational attainment information for 146 countries in 5-year intervals from 1950 to 2010. The data were estimated using information from survey/census data, disaggregated by sex and age group. Benchmark figures on school attainment were collected from UNESCO, Eurostat, national statistic agencies, and other sources and used as benchmark data points. When at least one benchmark figure was available from either an earlier or a later period, the missing observations were estimated by forward and backward extrapolation of the observations.

In order to obtain annual observations, the data have been linearly interpolated, under the hypothesis that the yearly variation is constant over time for the missing periods. This operation may be problematic because it generates a considerable amount of information. However, it is justified being also the original data estimated values, and given that the midand long- term trends of educational attainment over time seem to be generally positive and linear. Moreover, the strategy of interpolating data on education has been widely used in the literature of income inequality (Meschi \& Vivarelli, 2009).

\footnotetext{
${ }^{27}$ Available at: http://www.barrolee.com/.
} 
Appendix B

Overview of the data. Summary statistics.

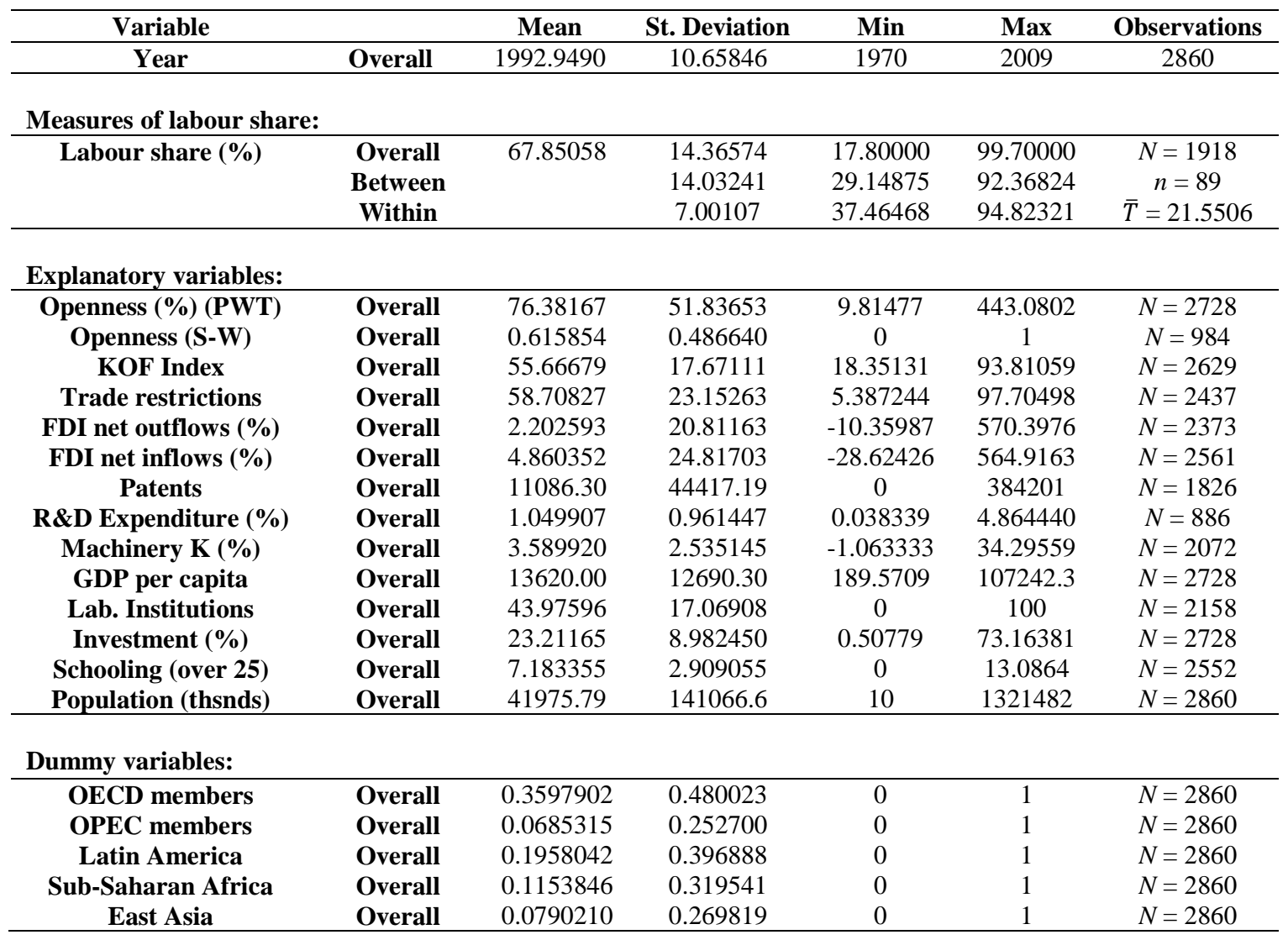

Overview of the data. Coefficients of correlation.

\begin{tabular}{|c|c|c|c|c|c|c|c|c|c|}
\hline & LS & $\begin{array}{c}\text { Openness } \\
\text { (PWT) }\end{array}$ & Patents & Ln(Gdp) & {$[\operatorname{Ln}(G d p)]^{2}$} & $\begin{array}{l}\text { Lab. reg. } \\
\text { index }\end{array}$ & Investment & Schooling & Ln(popul) \\
\hline LS & 1.0000 & & & & & & & & \\
\hline Openness (PWT) & $-0.1431 *$ & 1.0000 & & & & & & & \\
\hline Patents & 0.1503* & $-0.1901^{*}$ & 1.0000 & & & & & & \\
\hline Ln(Gdp) & $-0.0675 *$ & $0.1749 *$ & $0.1903^{*}$ & 1.0000 & & & & & \\
\hline$[\operatorname{Ln}(G d p)]^{2}$ & $-0.0686 *$ & $0.1792 *$ & $0.1966^{*}$ & $0.9969 *$ & 1.0000 & & & & \\
\hline Lab. reg. index & 0.1196* & -0.0315 & $-0.2860 *$ & -0.0045 & -0.0140 & 1.0000 & & & \\
\hline Investment & 0.0270 & $0.2820 *$ & $0.1177^{*}$ & $0.1389 *$ & $0.1278 *$ & $-0.1095 *$ & 1.0000 & & \\
\hline Schooling & $0.2302 *$ & $0.1497^{*}$ & $0.2042 *$ & $0.6977 *$ & $0.6946^{*}$ & $-0.0759 *$ & $-0.0617^{*}$ & 1.0000 & \\
\hline Ln(popul) & 0.0362 & $-0.4956 *$ & $0.3248 *$ & $-0.1024 *$ & $-0.1026 *$ & -0.0085 & $-0.2047^{*}$ & -0.0265 & 1.0000 \\
\hline
\end{tabular}


Appendix C

Labour share (LS6) and trade openness (PWT 7.0). Bivariate scatters and fitted lines.

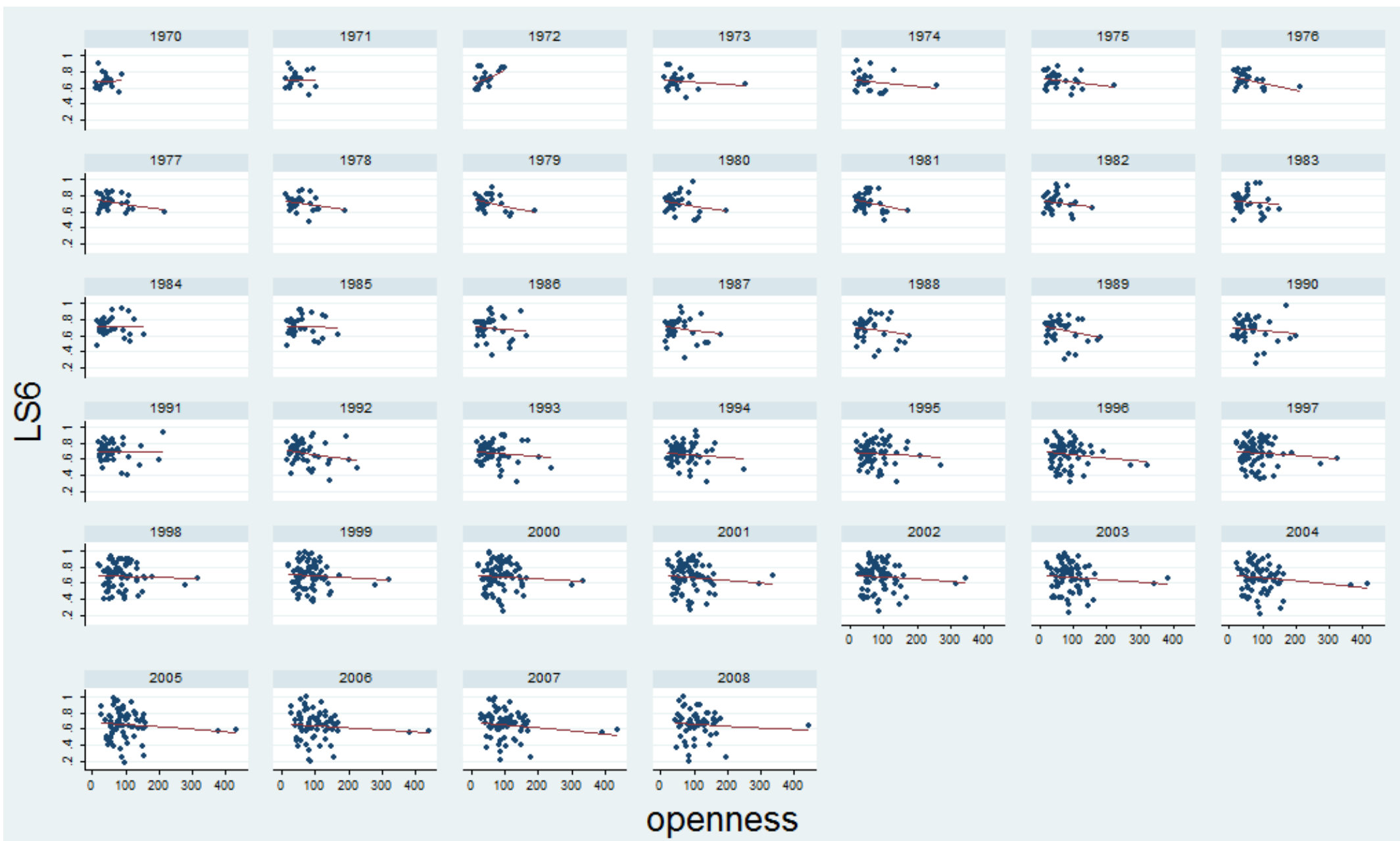

Source: Source: Author’s calculations. 
Appendix D

Labour share (LS6) and trade openness (PWT 7.0). Bivariate scatters (with the elimination of outlier observations) and fitted lines.

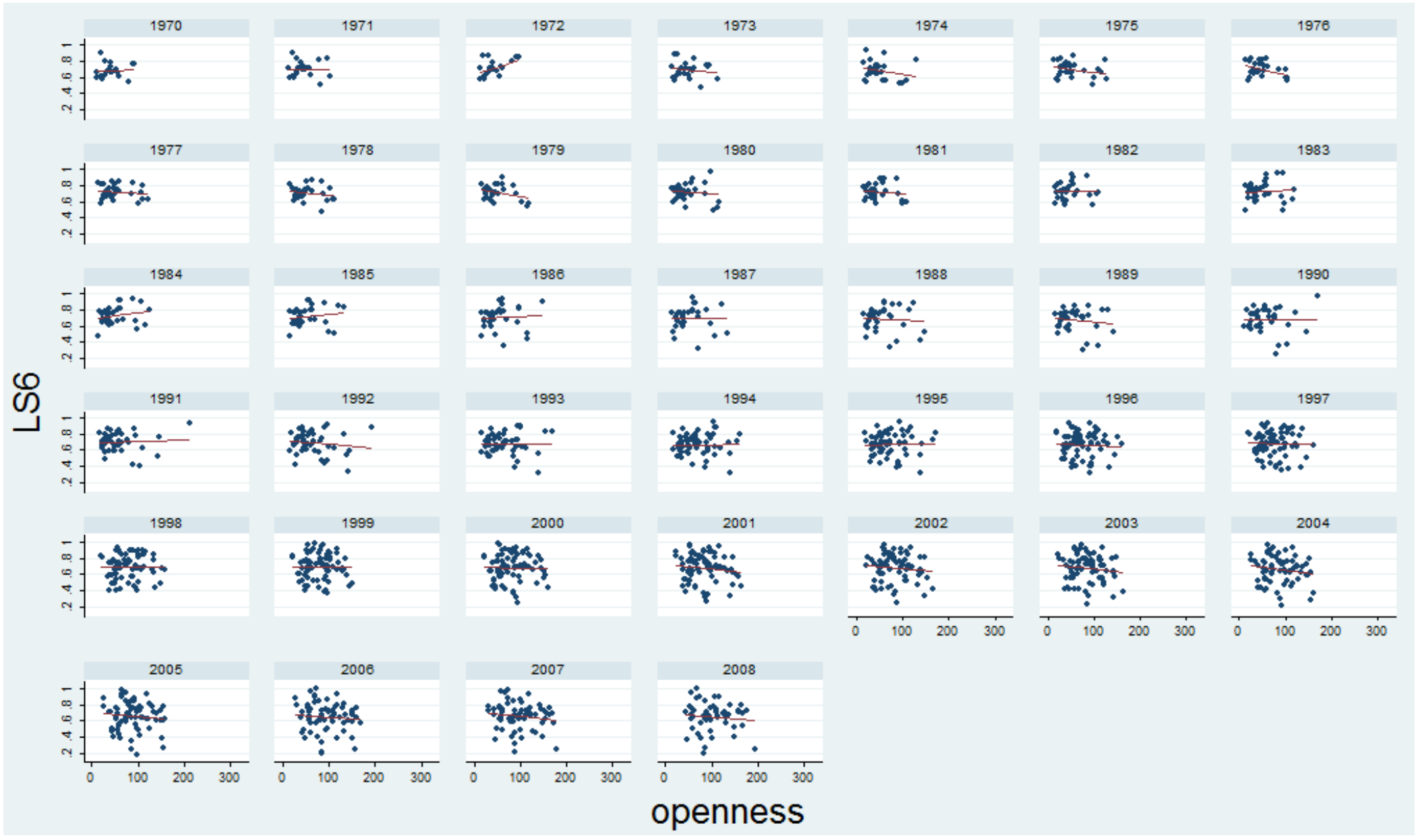

Source: Author's calculations. 
Appendix E

Labour share (LS6) and technology (patent applications). Bivariate scatters and fitted lines.

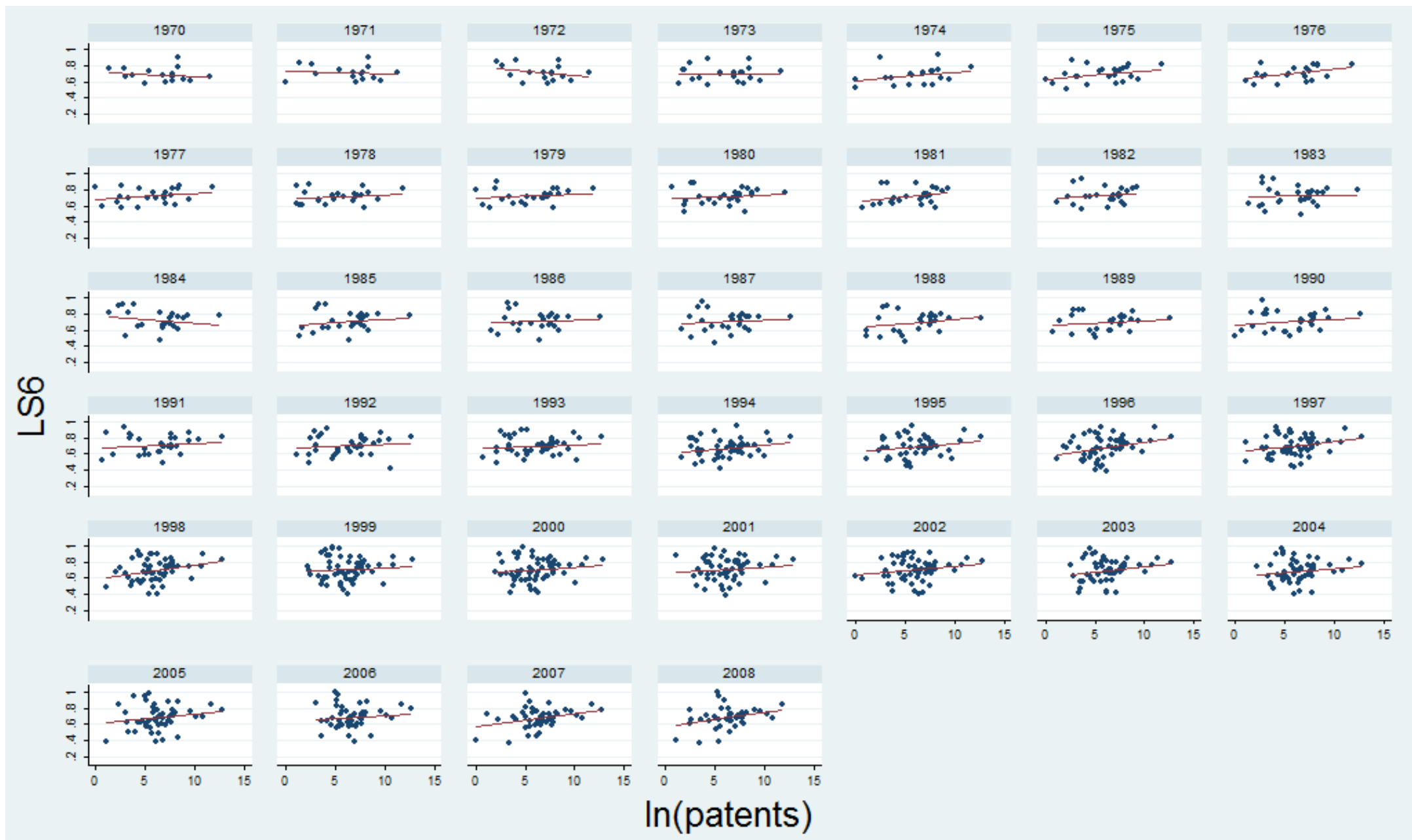

Source: Author’s calculations. 
Appendix F

Labour share (LS6) and technology (R\&D expenditure). Bivariate scatters and fitted lines.
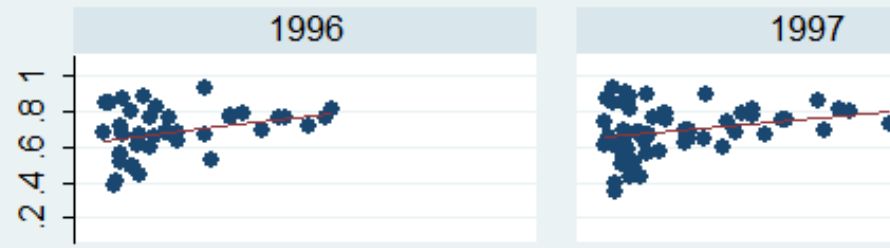

2001
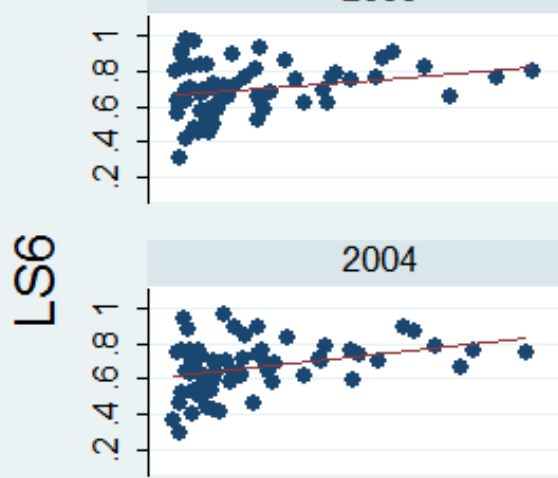

2008

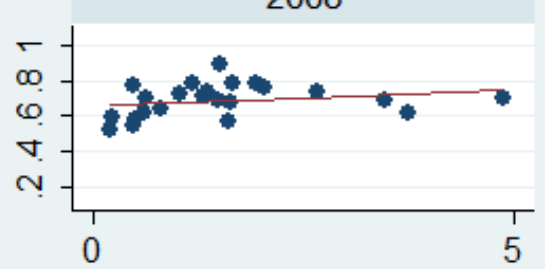

2005

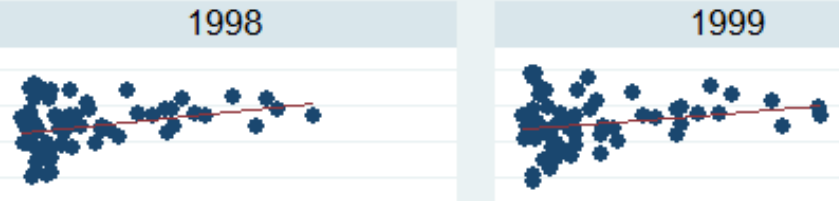

2002

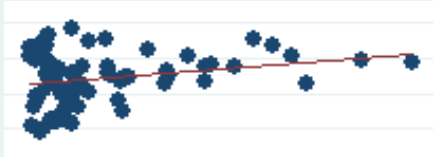

2006
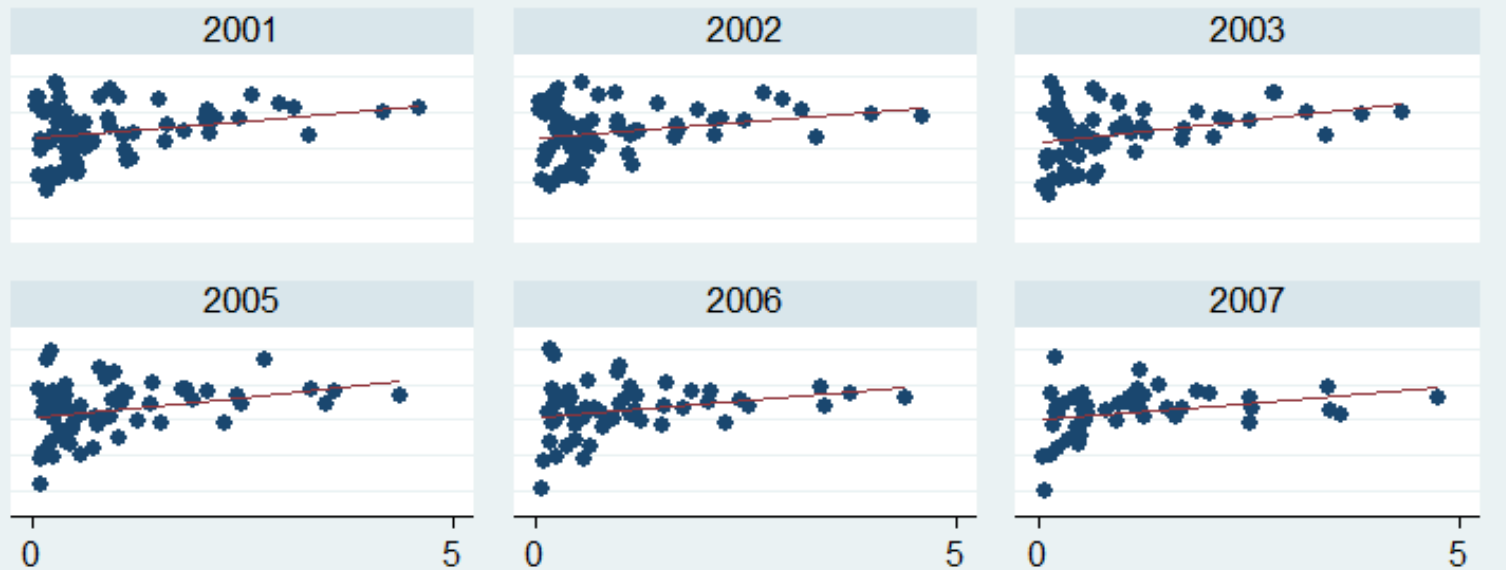

R\&D

Source: Author’s calculations. 
Appendix G

Labour share and trade openness. Country data.

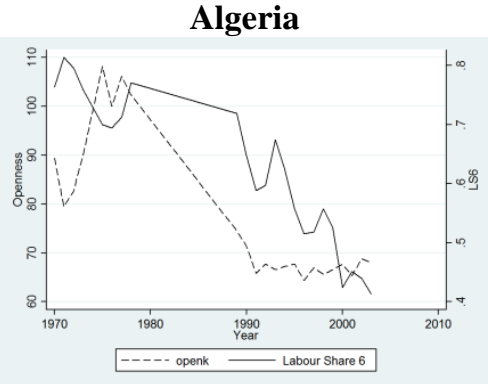

Belgium

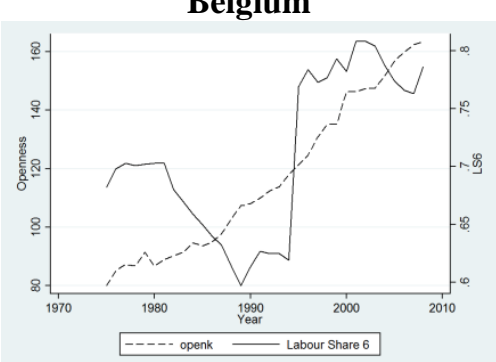

China, Hong Kong

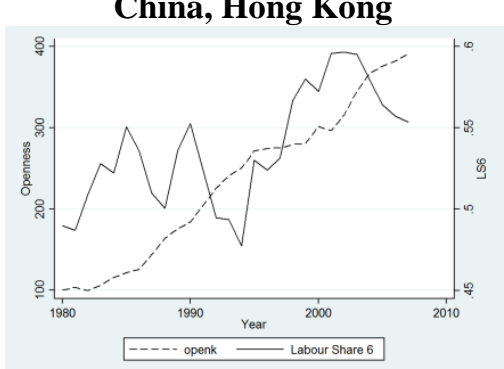

Argentina

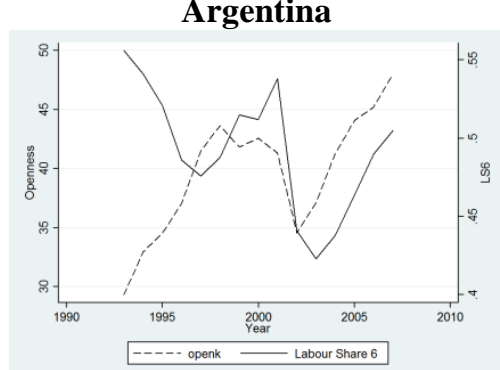

Botswana

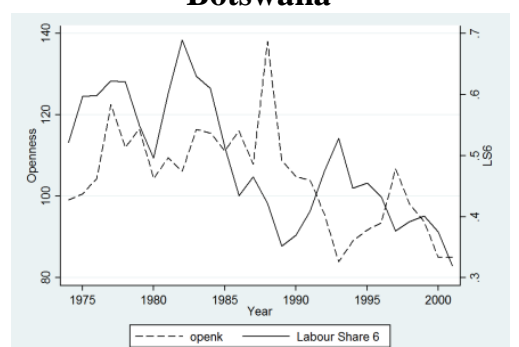

China, Macao

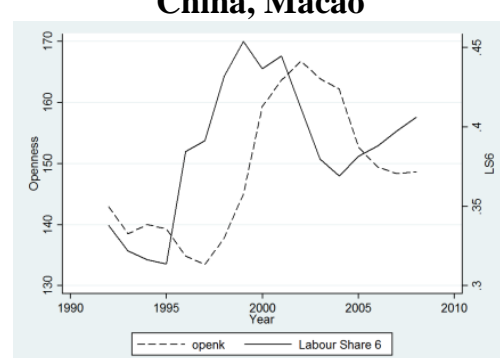

Armenia

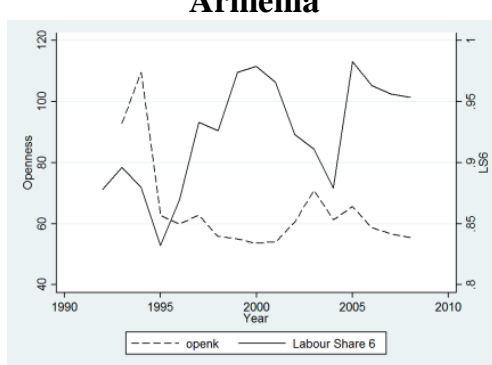

Brazil

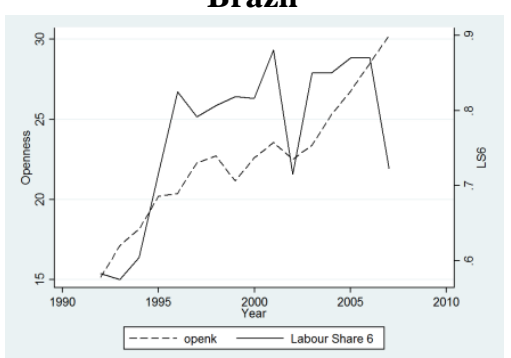

Colombia

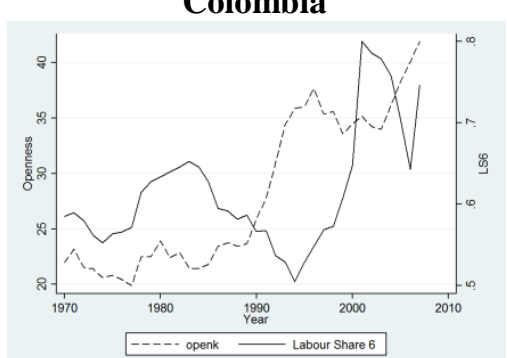

Australia

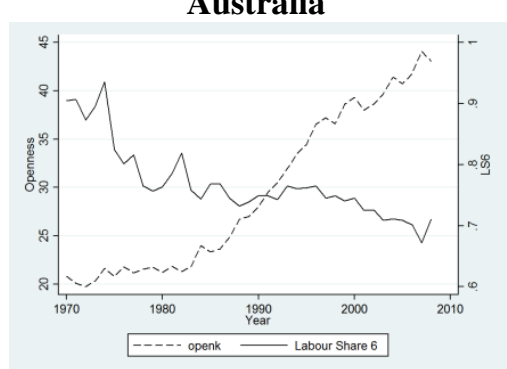

Blugaria

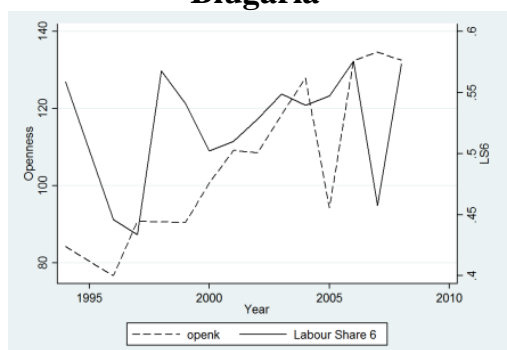

Costa Rica

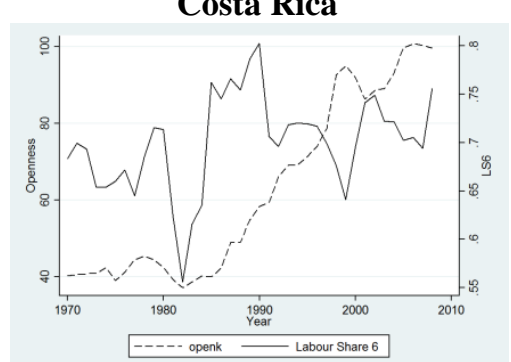

Austria
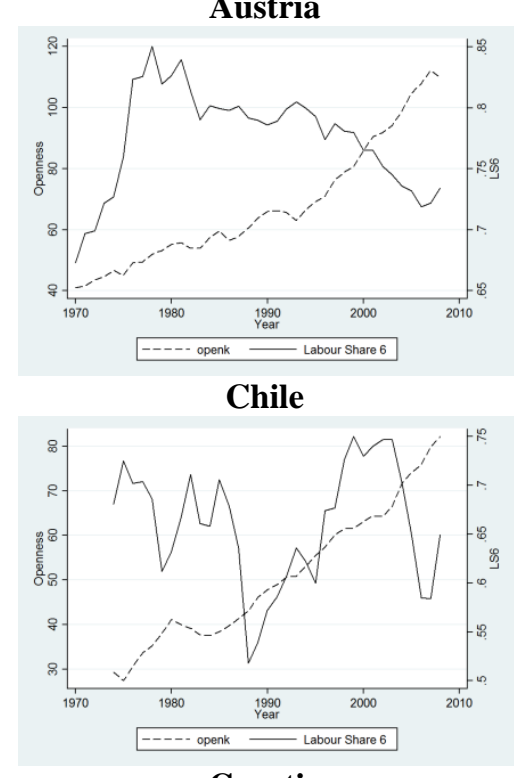

Croatia

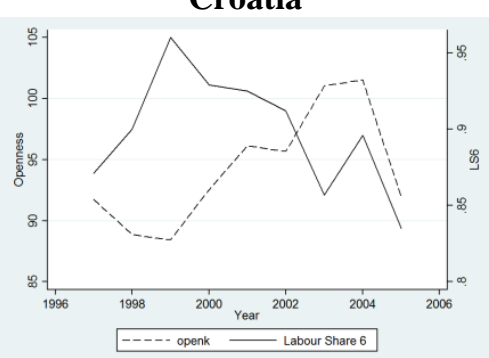




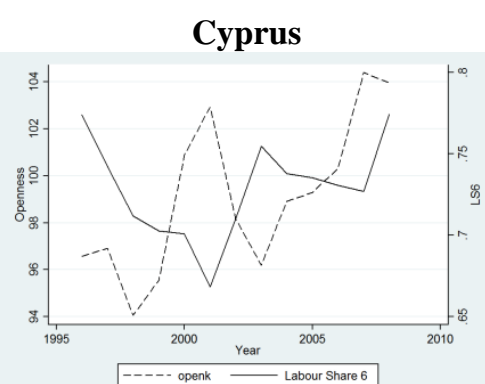

Fiji

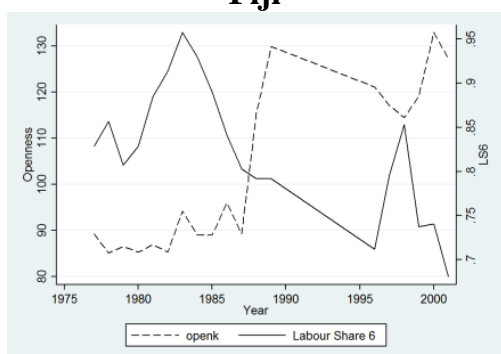

Greece

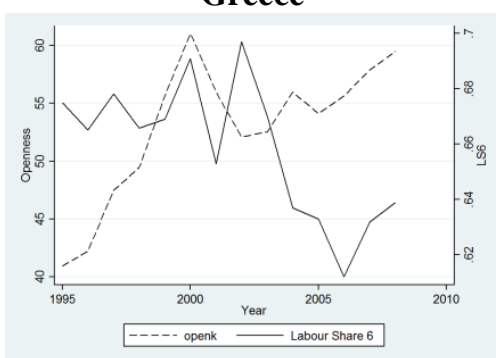

Czech Republic

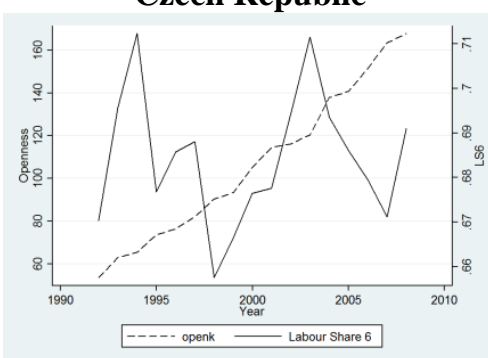

Finland

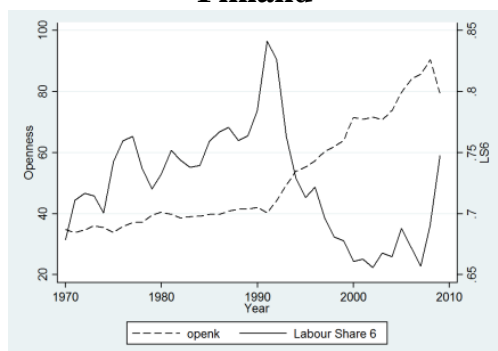

Hungary

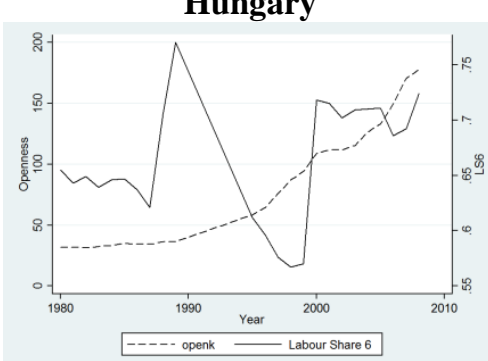

Egypt

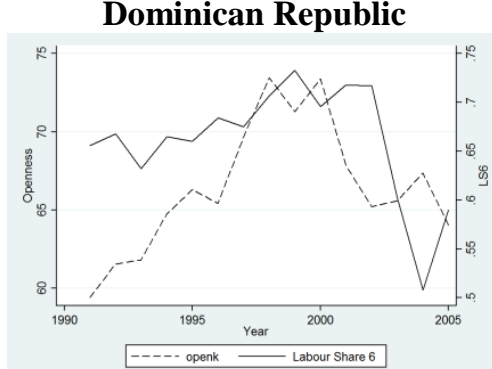

France

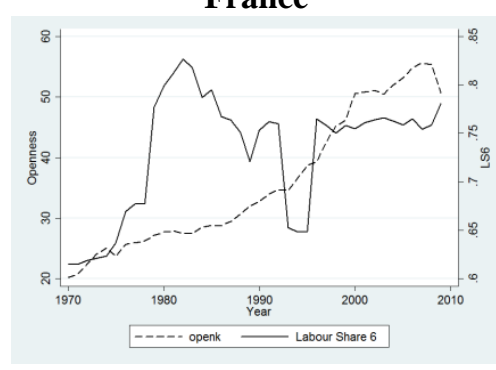

Iceland

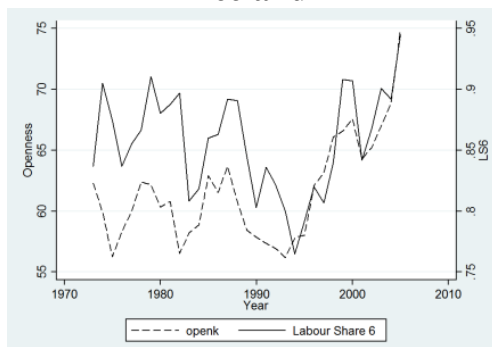

Gabon

Iran
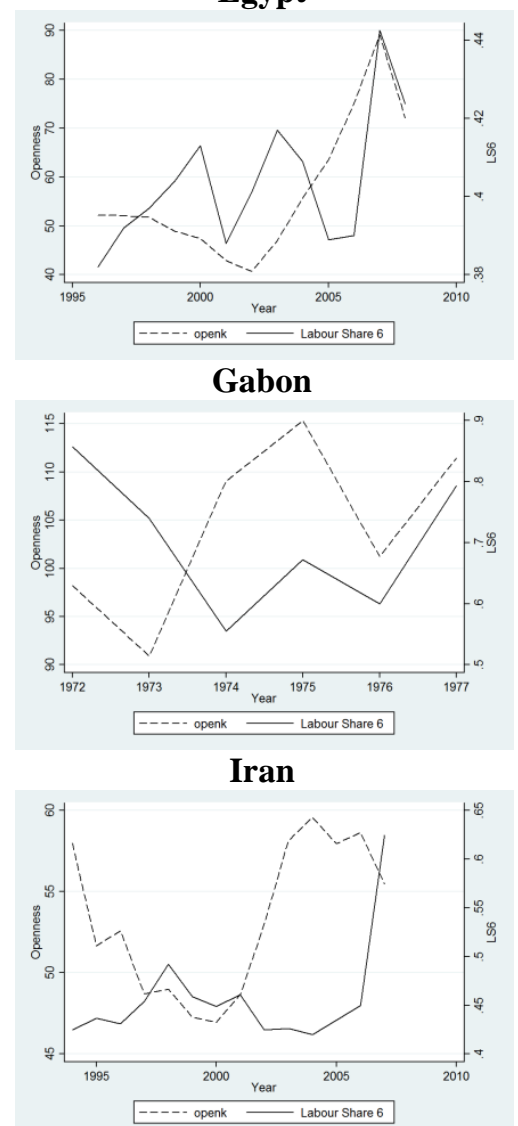

Estonia

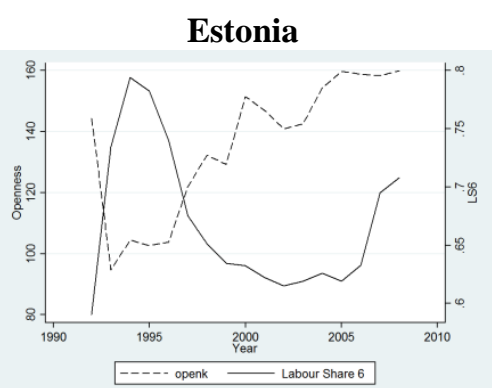

Germany

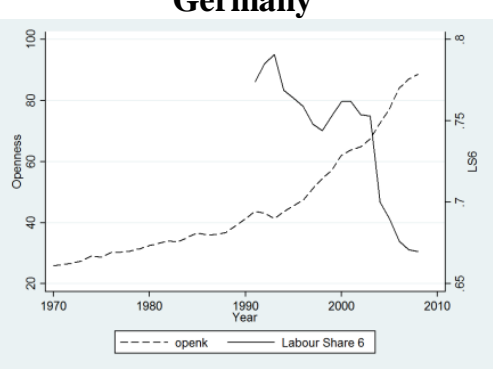

Ireland

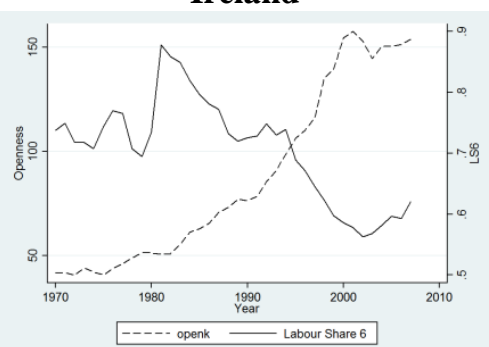




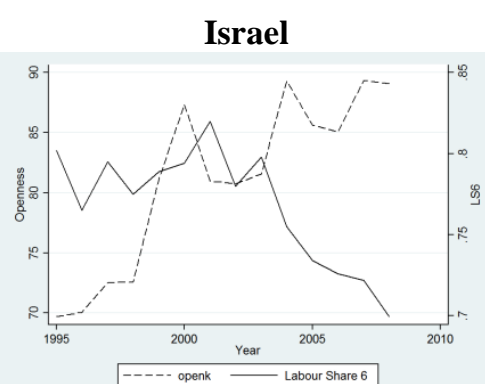

Republic of Korea

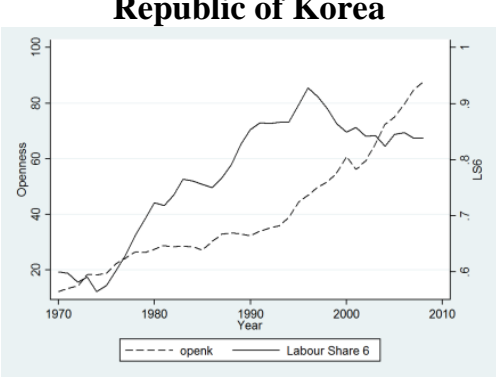

Malaysia

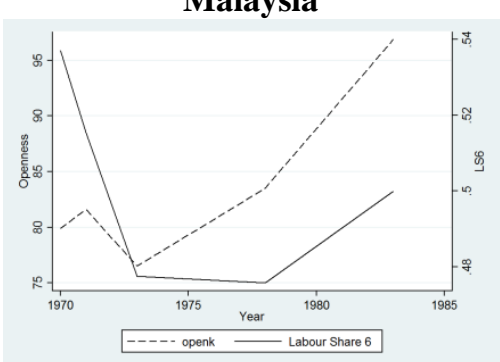

Italy

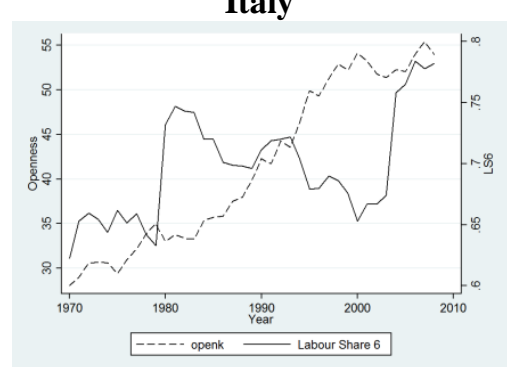

Kuwait

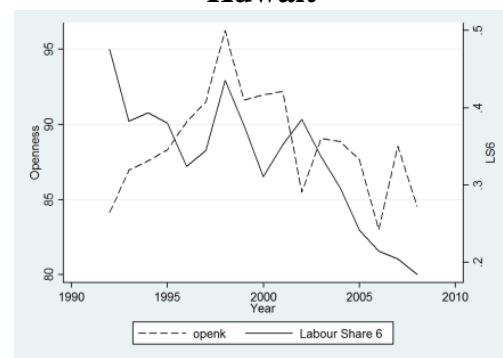

Malta

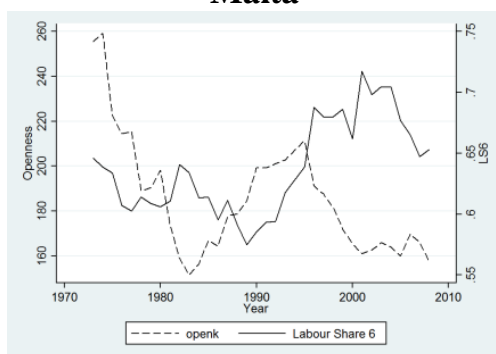

Jamaica

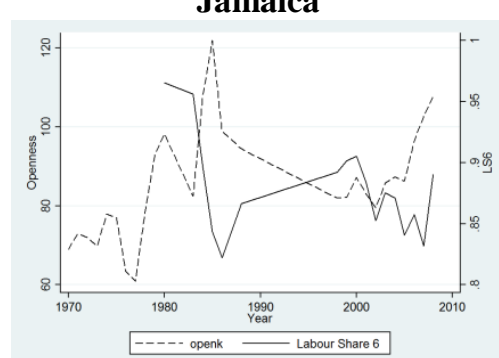

Kyrgyzstan

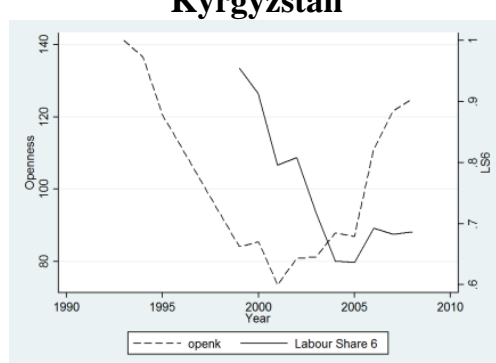

Mauritius

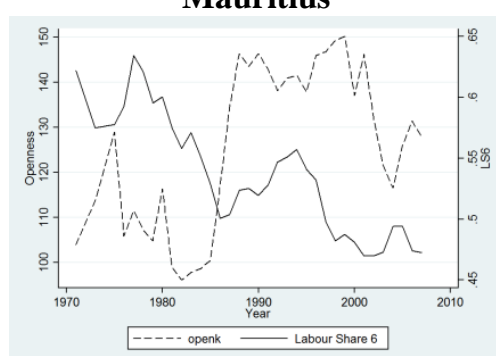

Japan

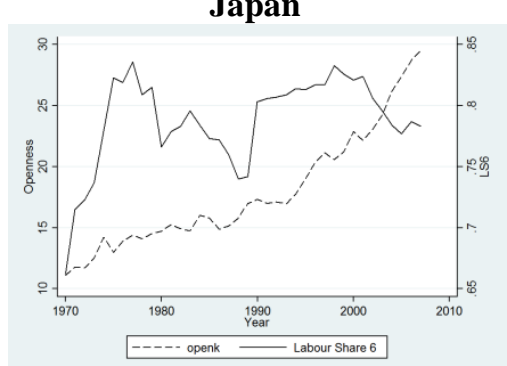

Latvia

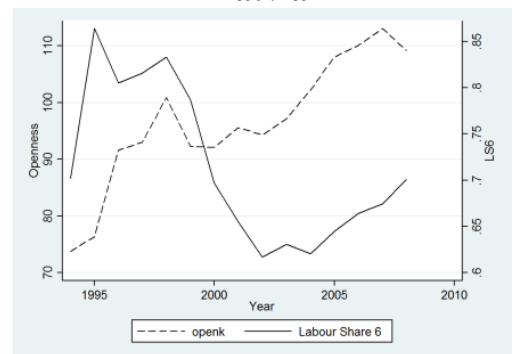

Mexico

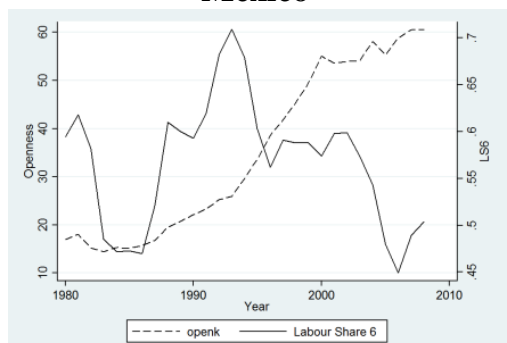

Kazakhstan

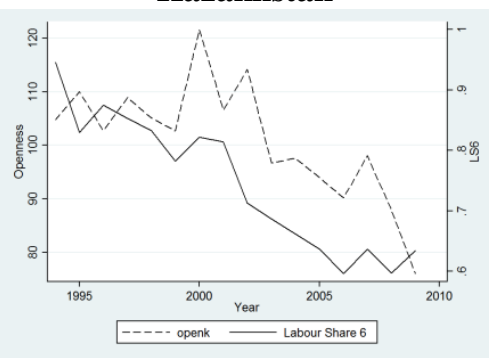

Lithuania

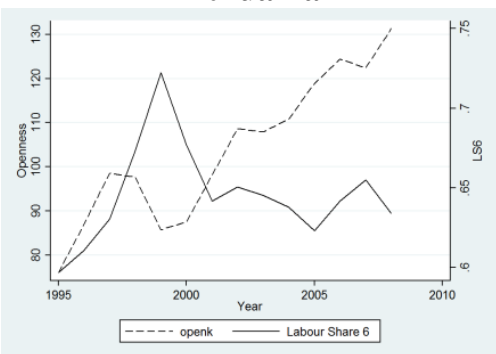

Mongolia

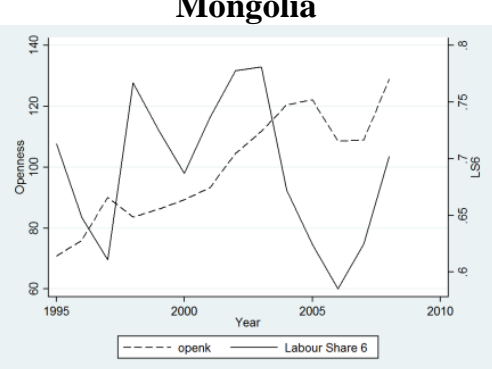




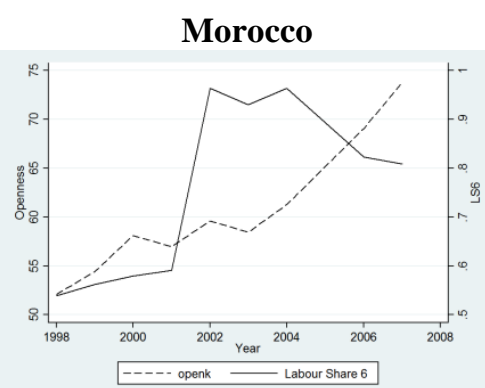

Norway

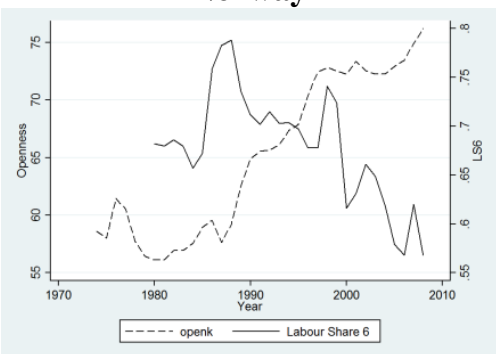

Philippines

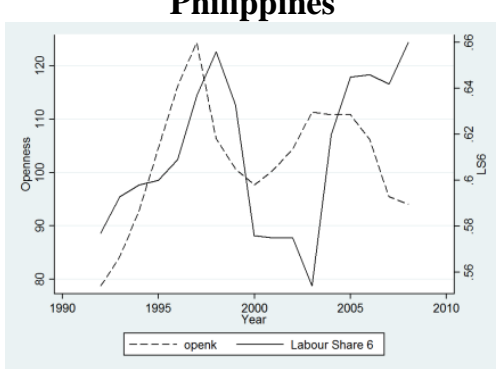

Namibia

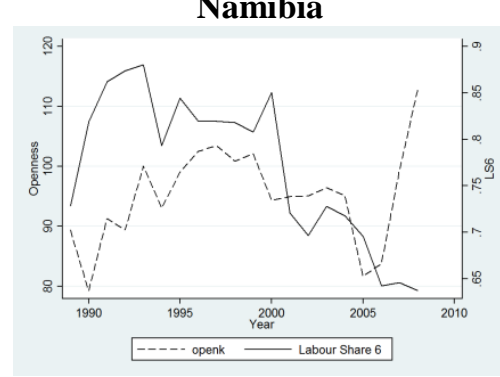

Oman

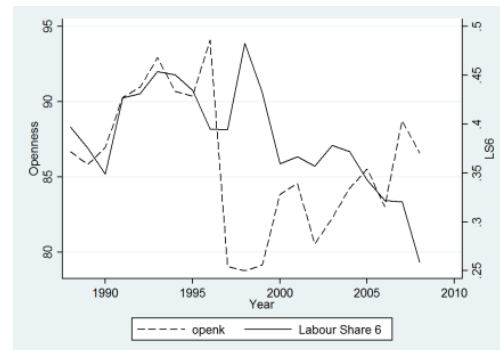

Poland

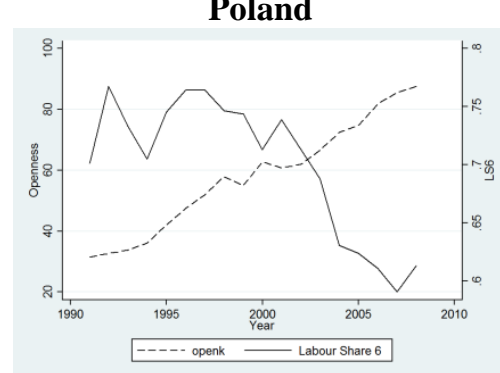

Netherlands

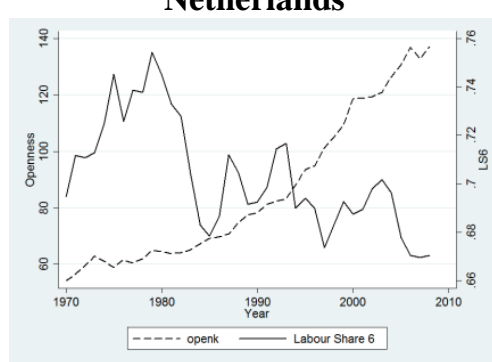

Panama

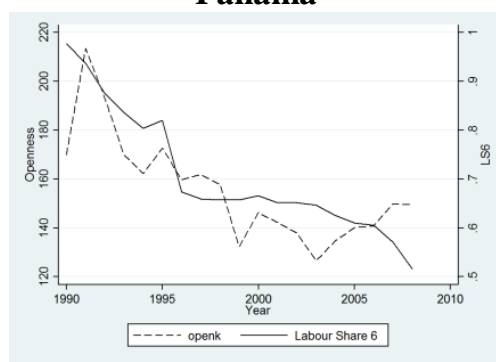

Portugal

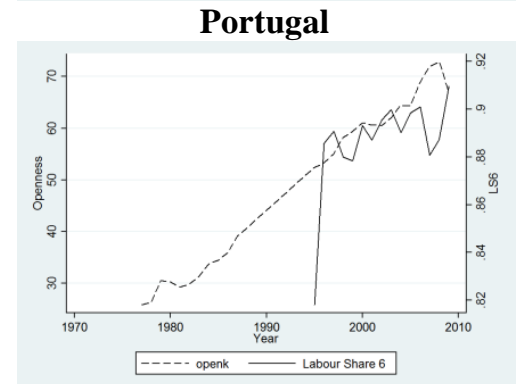

New Zealand

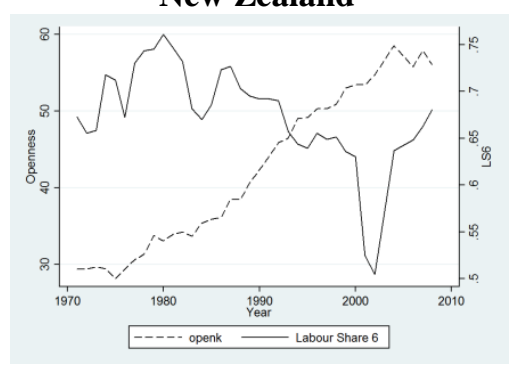

Paraguay

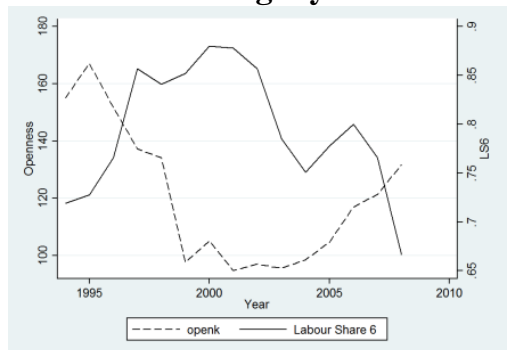

Qatar

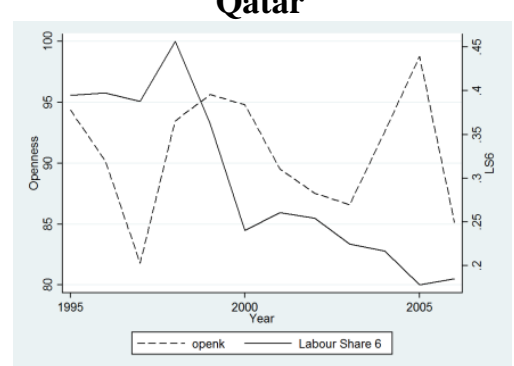

Nicaragua

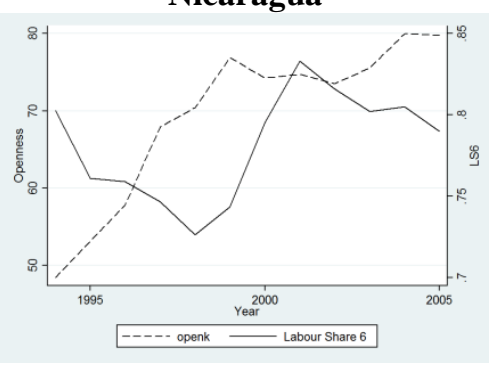

Peru

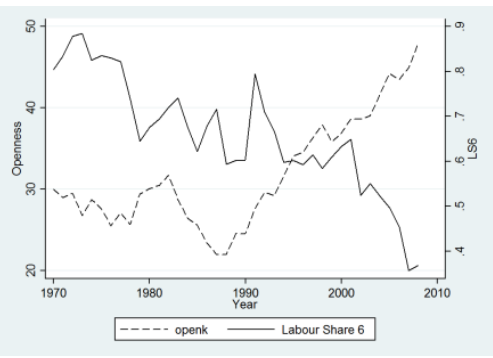

Romania

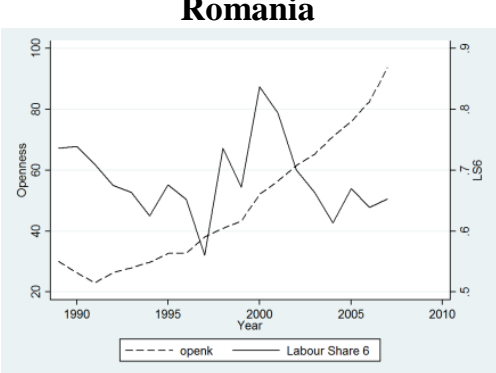




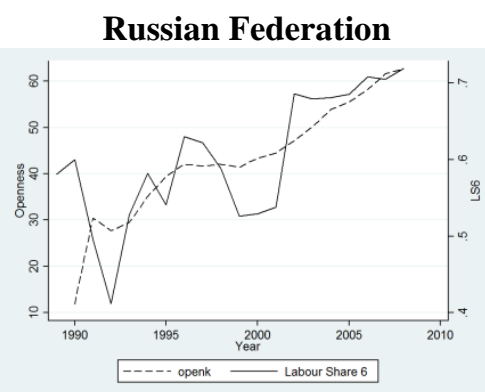

Spain

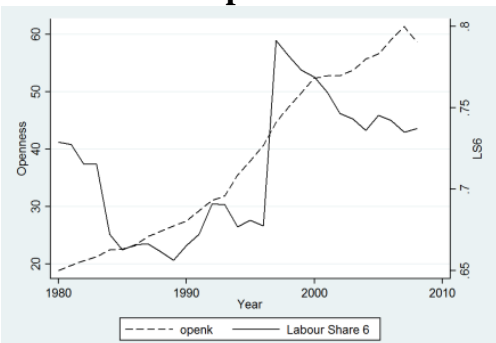

Republic of Macedonia

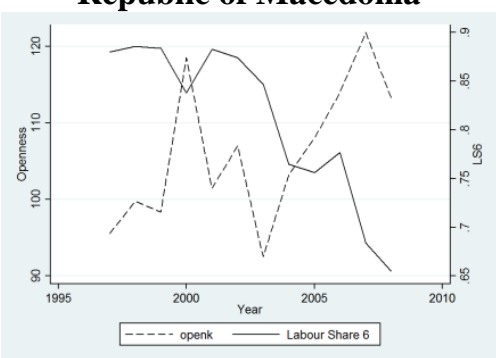

Singapore

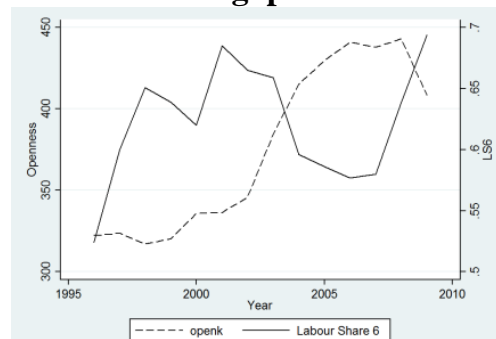

Sri Lanka

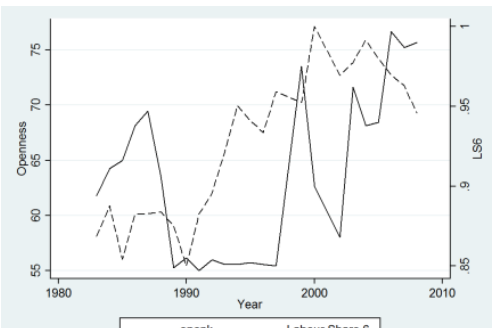

Trinidad \& Tobago

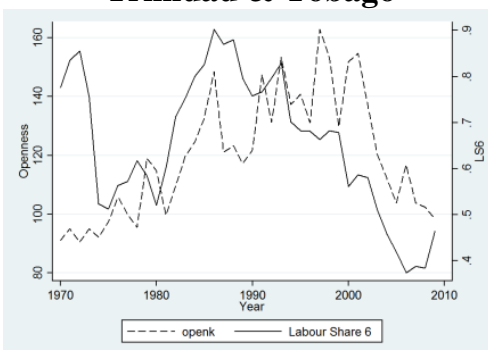

Slovakia

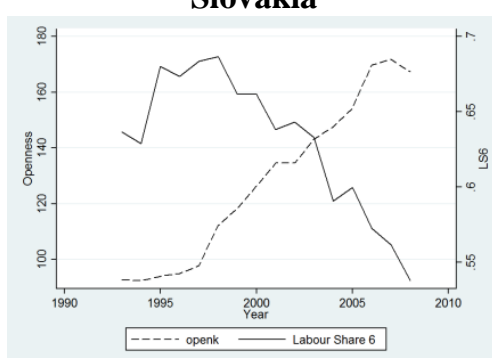

Sweden

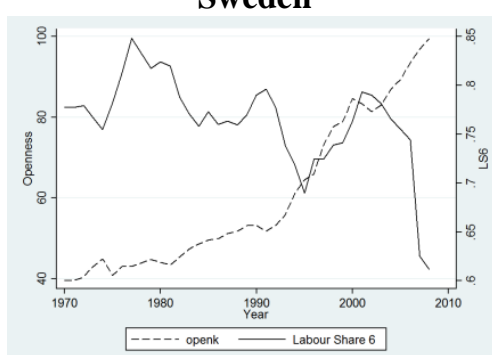

Tunisia

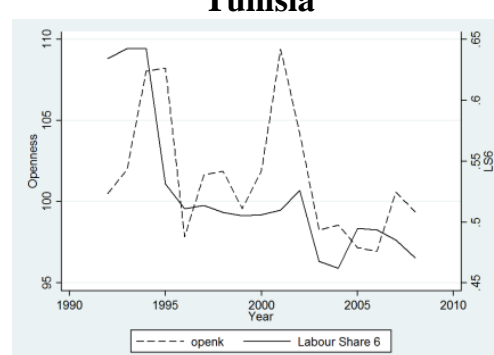

Slovenia

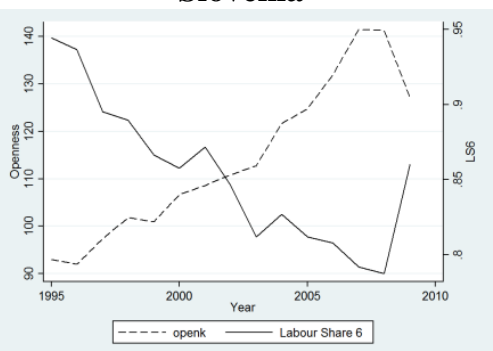

Switzerland

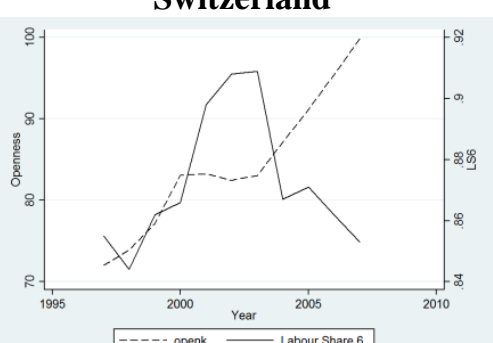

Turkey

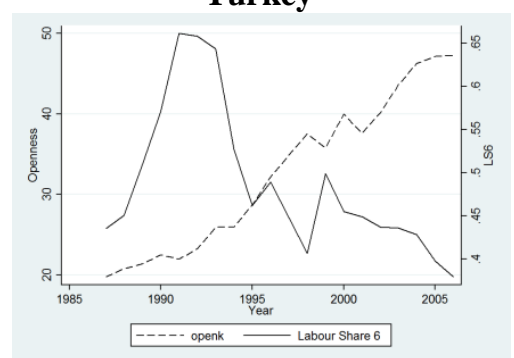

South Africa

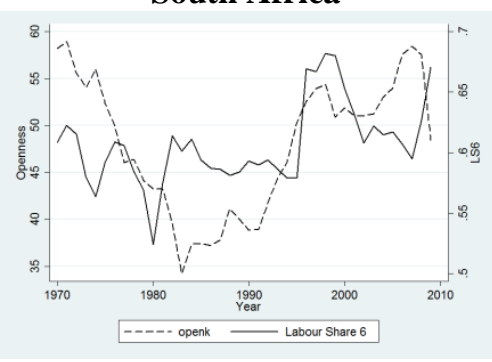

Thailand

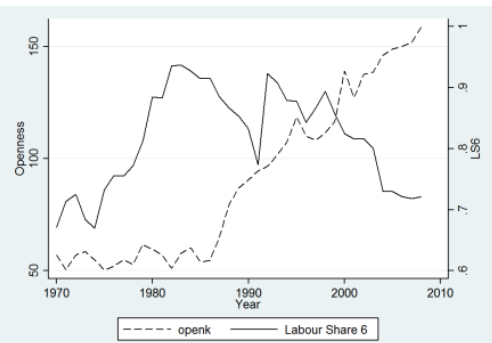

United Arab Emirates

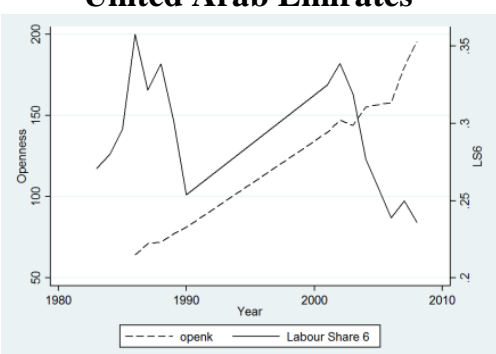



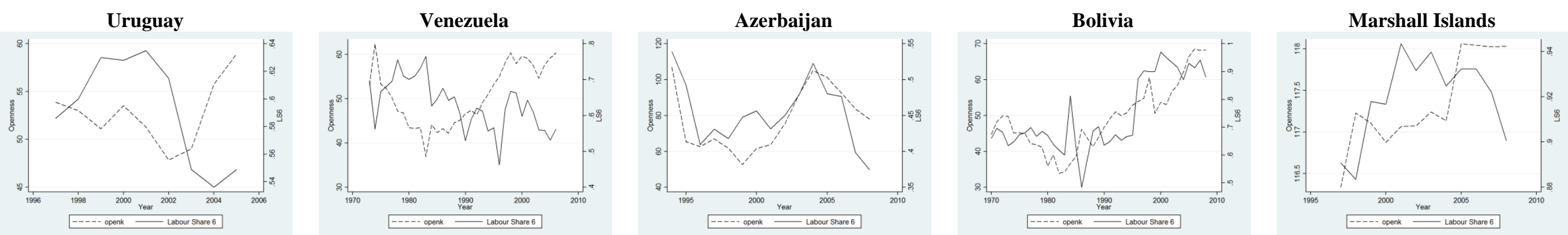

Source: Author's calculations.

\section{Appendix $\mathbf{H}$}

Labour share and patents applications. Country data.

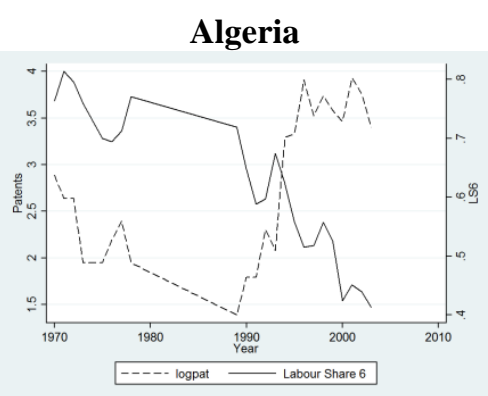

Belgium

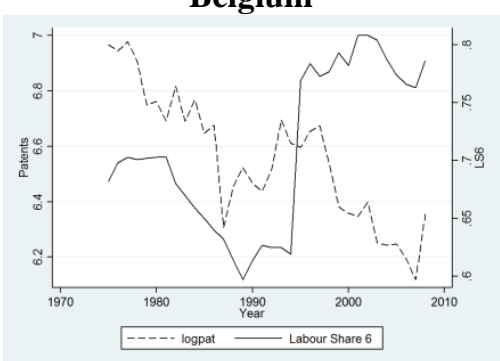

Argentina

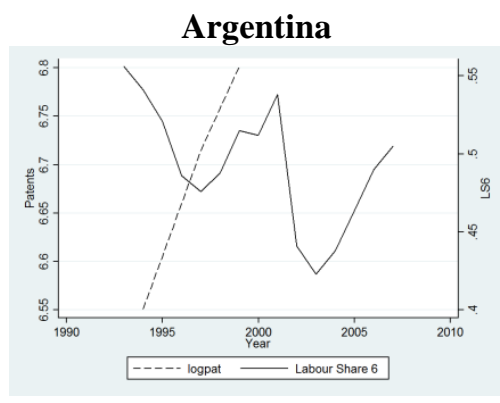

Brazil

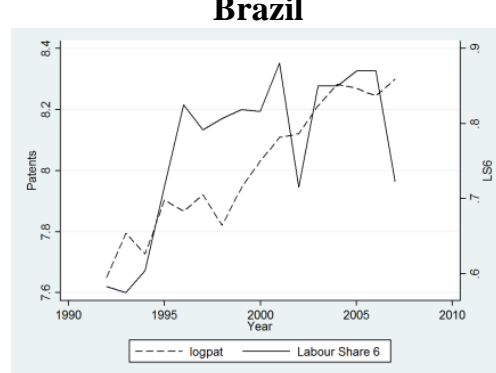

Armenia

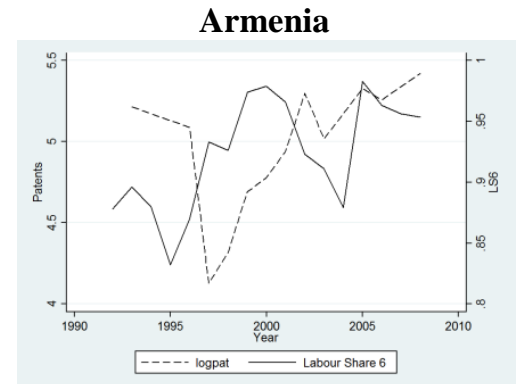

Bulgaria

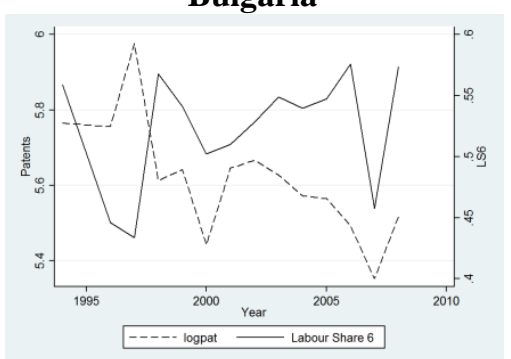

Australia

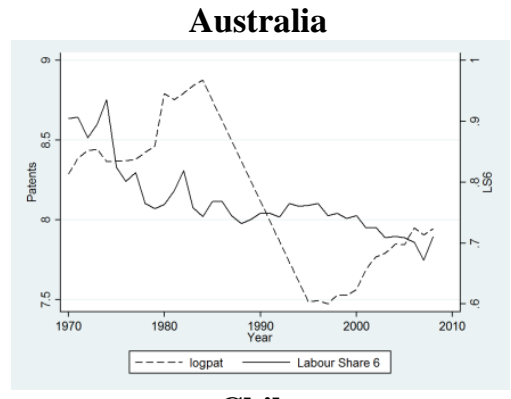

Chile

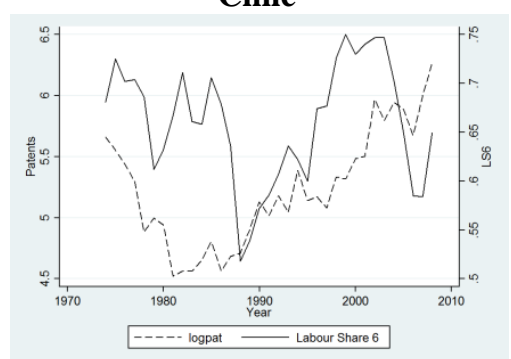

Austria

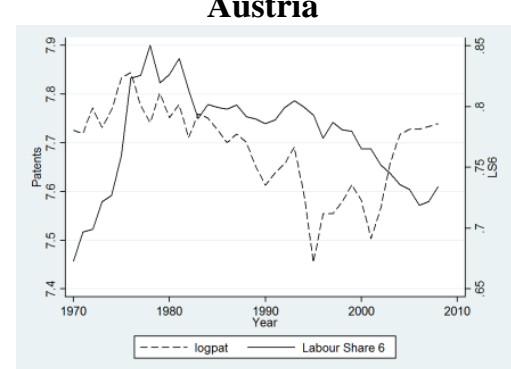

China, Hong Kong

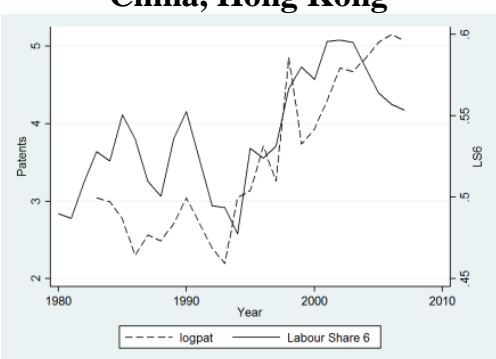




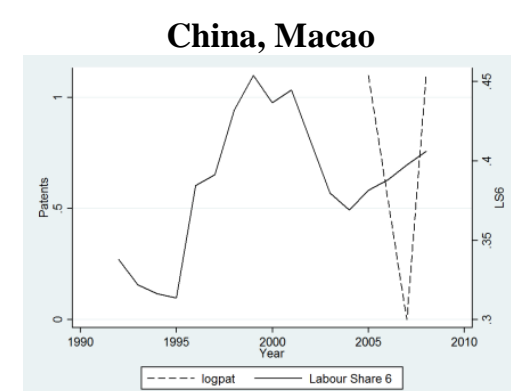

Czech Republic

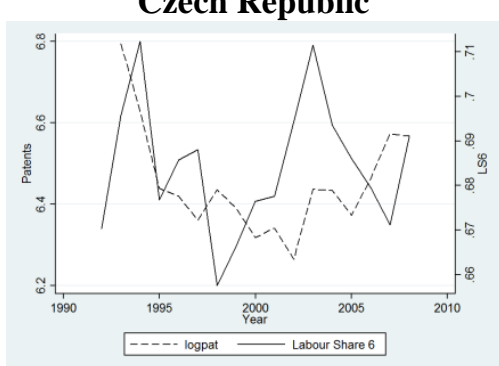

France

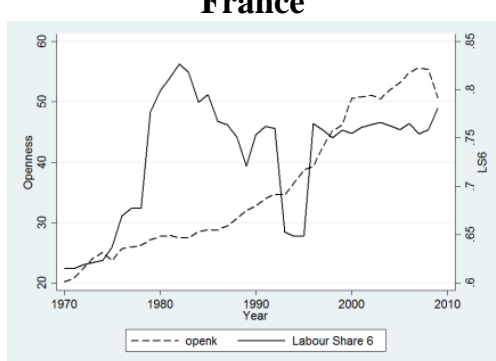

Colombia

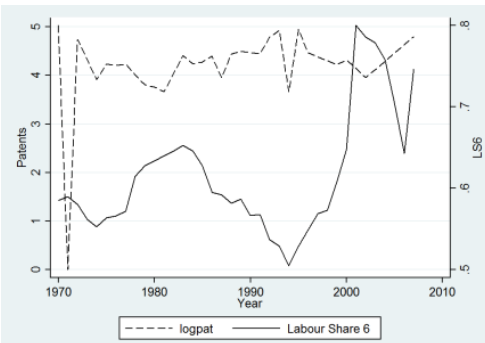

Egypt

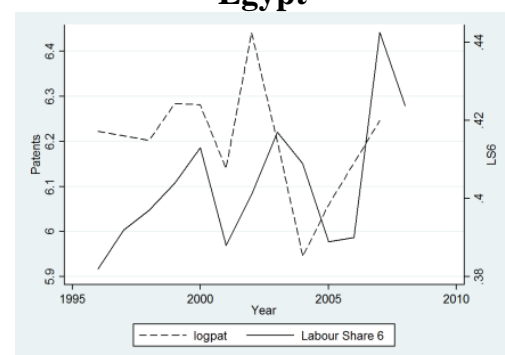

Germany

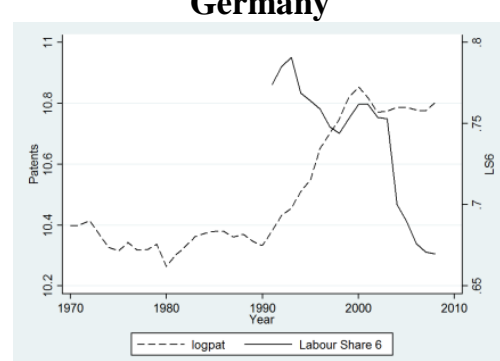

Costa Rica

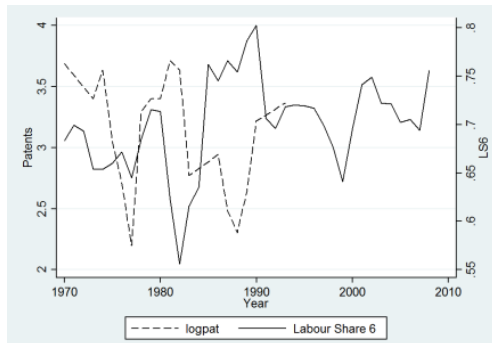

Estonia

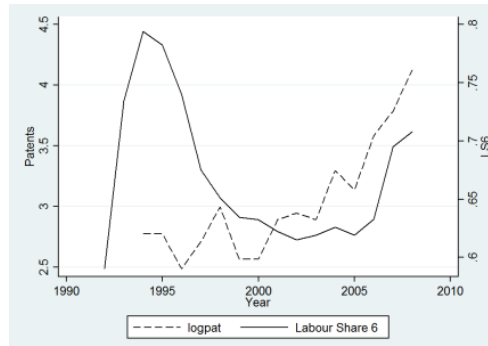

Greece

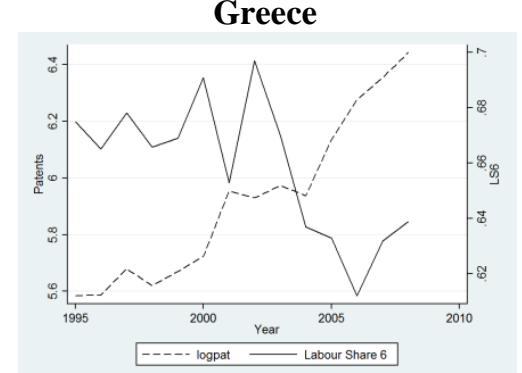

Croatia

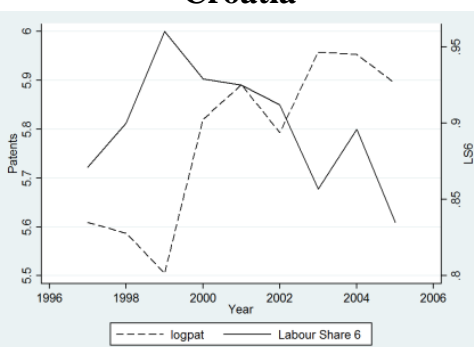

Fiji

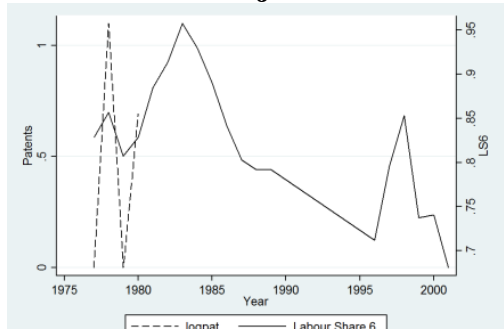

Hungary

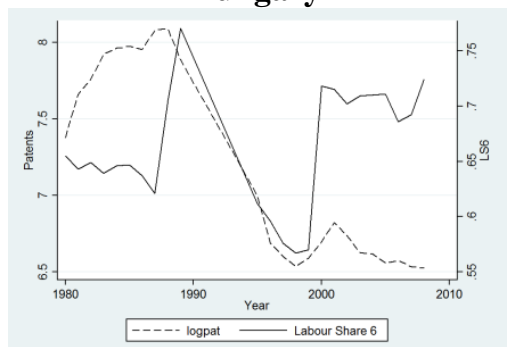

Cyprus

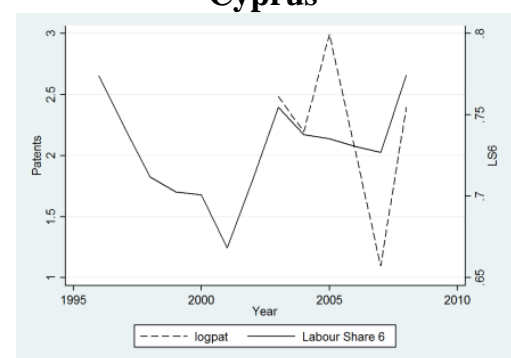

Finland

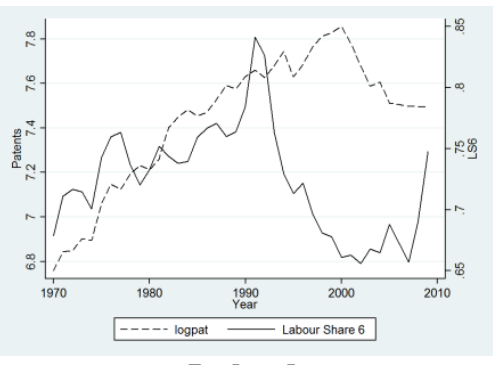

Iceland

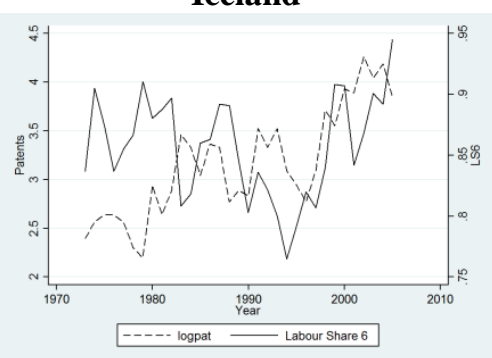




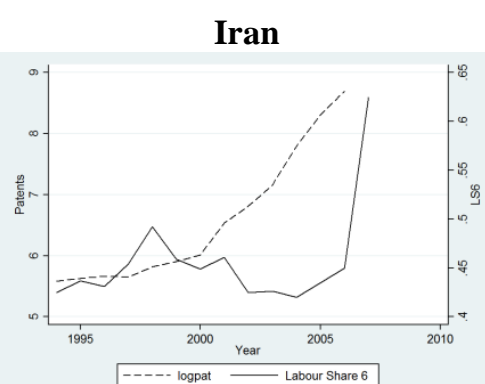

Japan

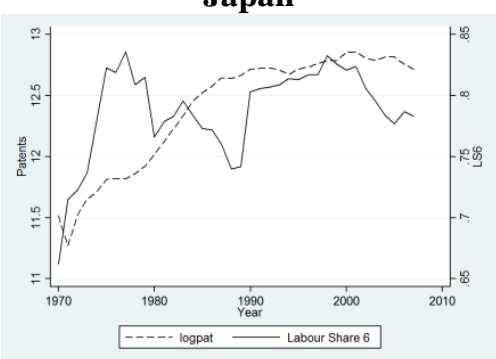

Lithuania

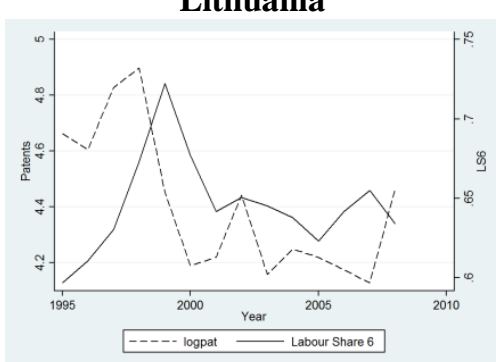

Ireland

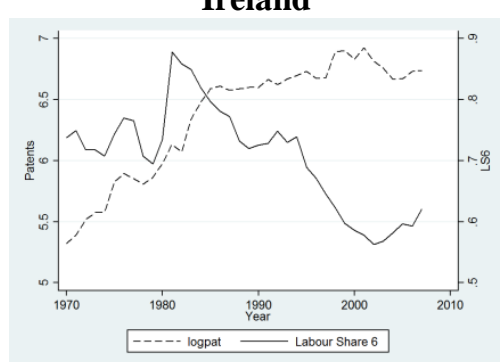

Kazakhstan

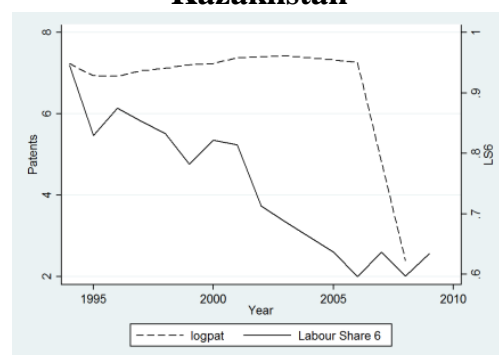

Malta

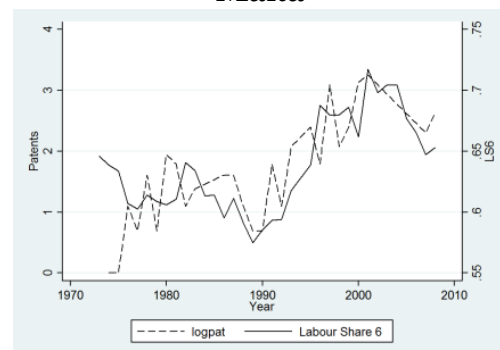

Israel

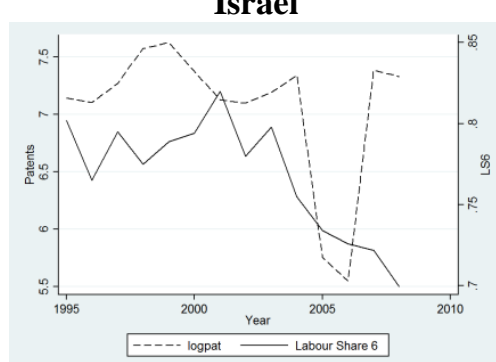

Republic of Korea

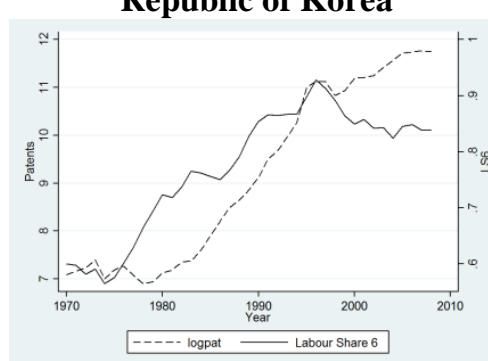

Mauritius

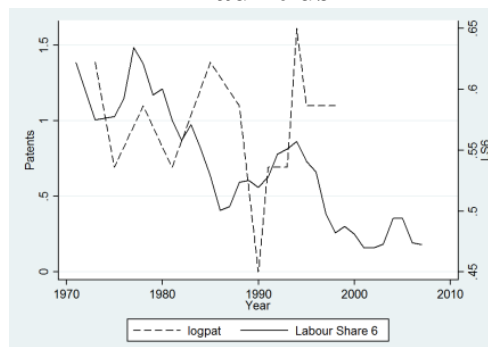

Italy

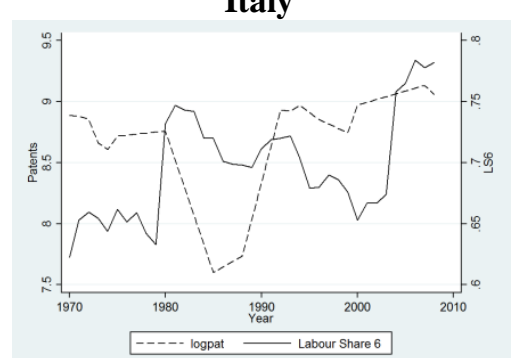

Kyrgyzstan

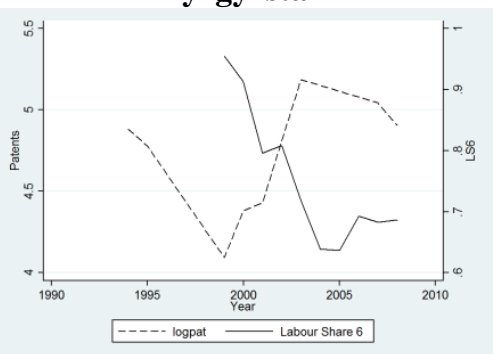

Mexico

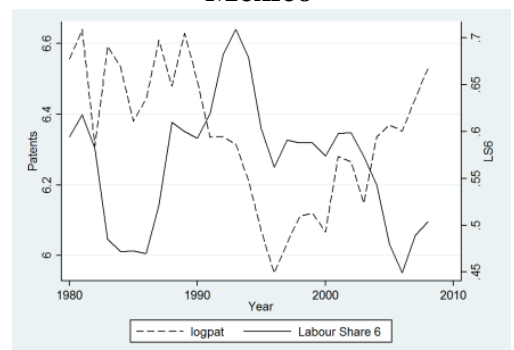

Jamaica

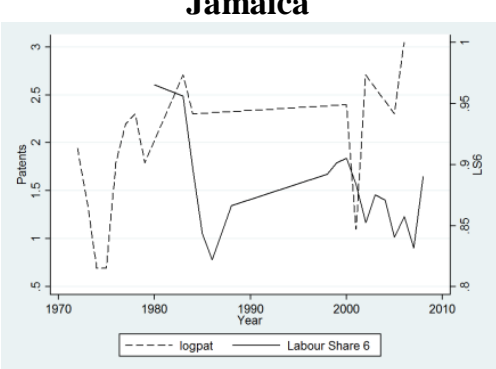

Latvia

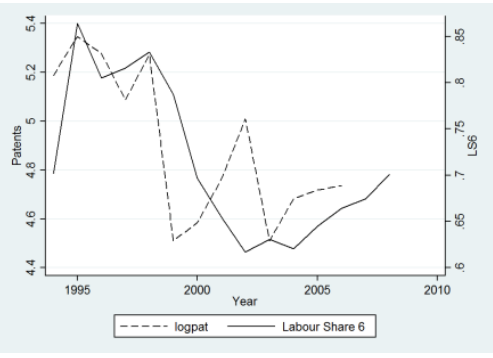

Mongolia

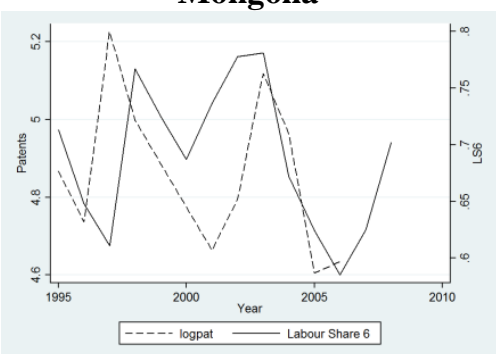




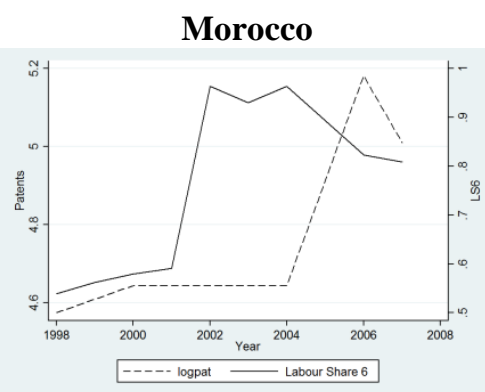

Norway

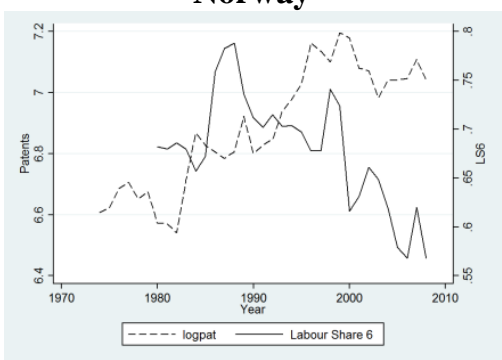

Portugal

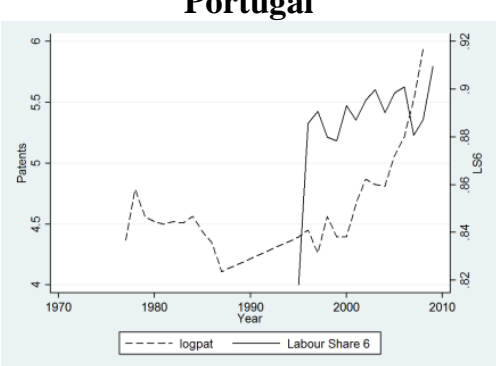

Namibia

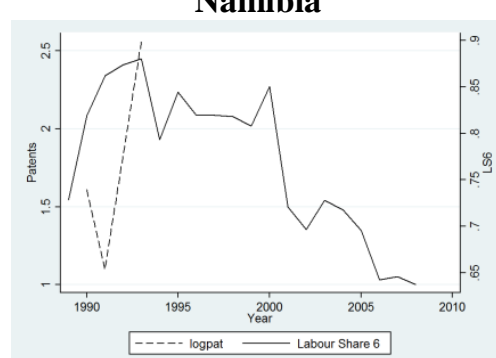

Panama

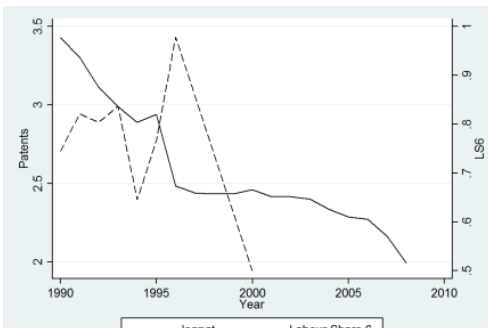

Republic of Moldova

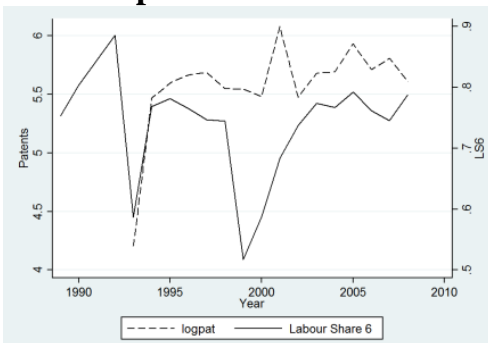

Netherlands

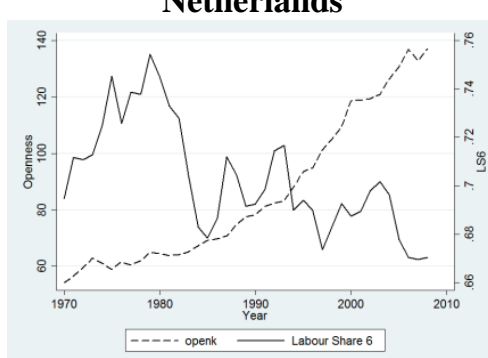

Peru

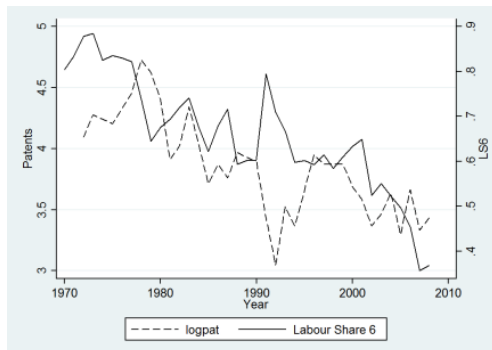

Romania

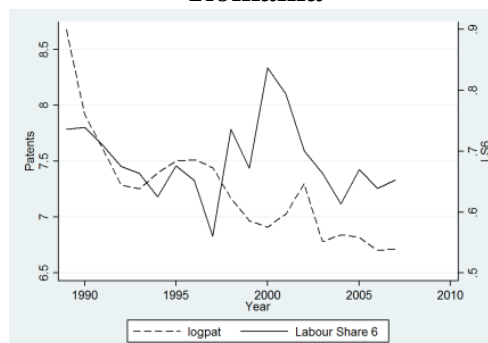

New Zealand

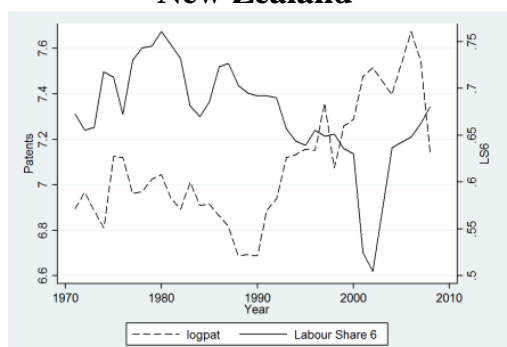

Philippines

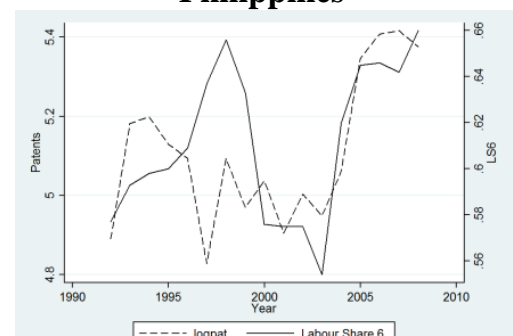

Russian Federation

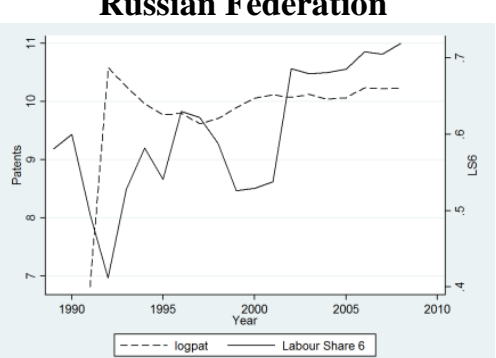

Nicaragua

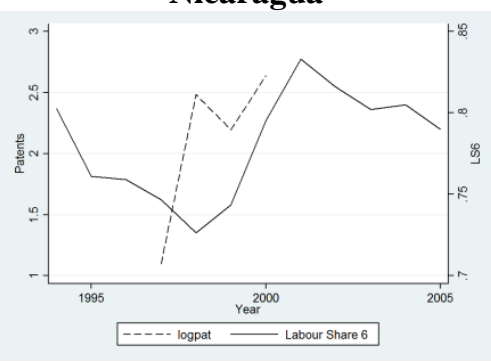

Poland

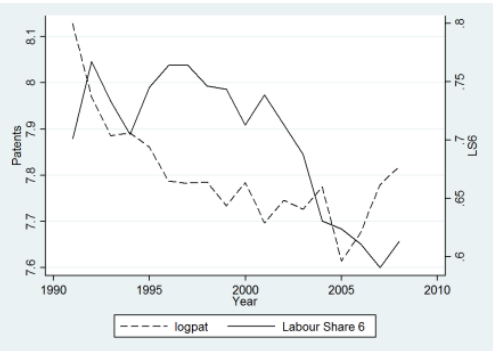

Singapore

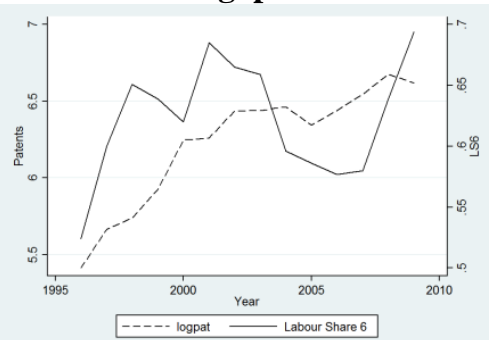



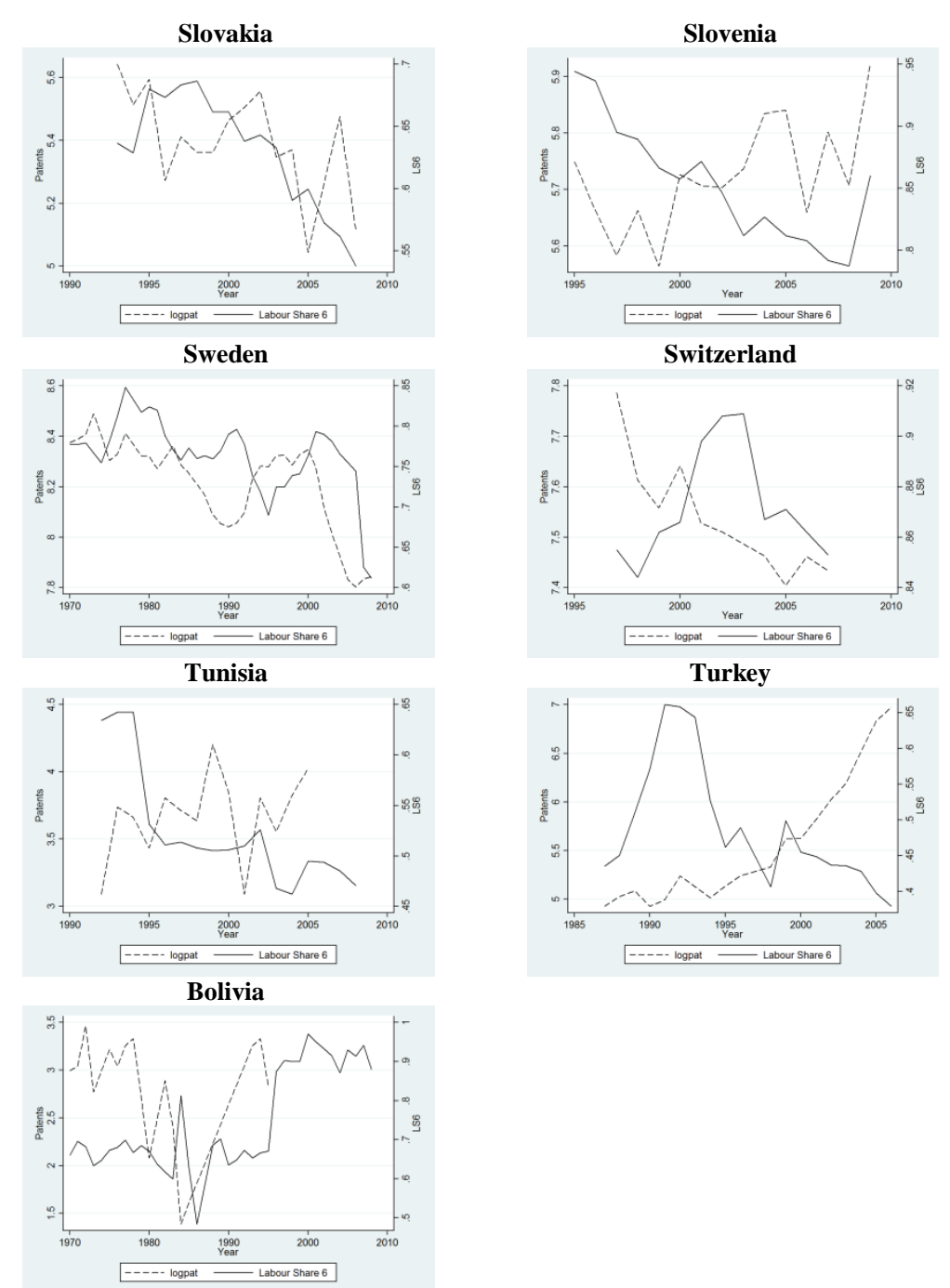

Source: Author's calculations.
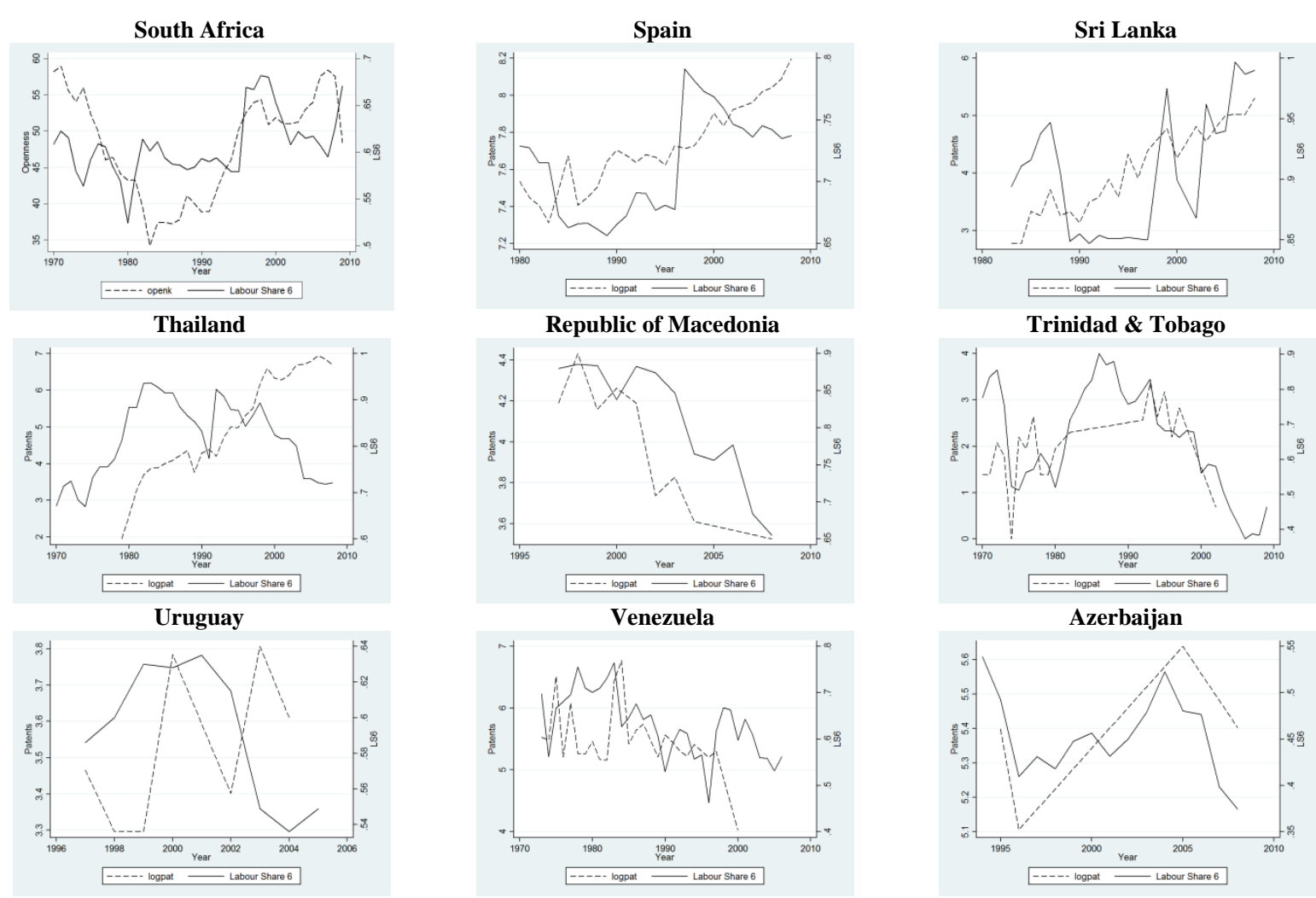
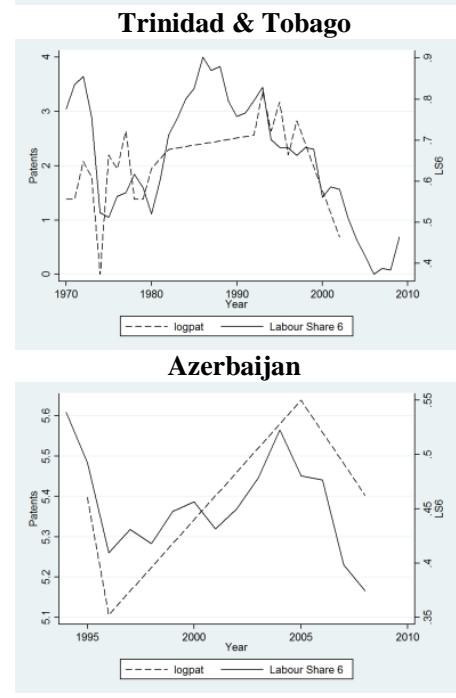
Appendix I

IV estimation (xtivreg, fe). Instrumentation with one-year lags.

\begin{tabular}{|c|c|c|c|c|c|c|c|}
\hline \multirow{2}{*}{$\begin{array}{c}\text { Dep. var.: } \\
\text { LS (\%) }\end{array}$} & \multirow{2}{*}{$\begin{array}{c}\text { Openness } \\
\text { (1) }\end{array}$} & \multirow{2}{*}{$\begin{array}{c}\text { Tech. progress } \\
\text { (2) }\end{array}$} & \multicolumn{2}{|c|}{ Economic development } & \multirow{2}{*}{$\begin{array}{c}\text { Lab. market } \\
\text { Institutions } \\
\text { (5) }\end{array}$} & \multirow{2}{*}{$\begin{array}{c}\text { Investment } \\
(6)\end{array}$} & \multirow{2}{*}{$\begin{array}{c}\text { Human capital } \\
\text { (7) }\end{array}$} \\
\hline & & & (3) & (4) & & & \\
\hline Openness & $\begin{array}{c}\mathbf{0 . 0 4 5 3}^{\text {**** }} \\
(0.0105)\end{array}$ & $\begin{array}{c}0.0140 \\
(0.0122)\end{array}$ & $\begin{array}{l}0.00172 \\
(0.0123)\end{array}$ & $\begin{array}{l}0.00748 \\
(0.0123)\end{array}$ & $\begin{array}{c}0.0200 \\
(0.0165)\end{array}$ & $\begin{array}{c}0.0192 \\
(0.0166)\end{array}$ & $\begin{array}{l}\mathbf{0 . 0 3 8 7}^{\text {** }} \\
(0.0164)\end{array}$ \\
\hline Patents & & $\begin{array}{c}\mathbf{0 . 0 0 0 0 3 9 8}^{\text {****}} \\
(0.0000103)\end{array}$ & $\begin{array}{l}\mathbf{0 . 0 0 0 0 2 8 0}^{* * *} \\
(0.0000105)\end{array}$ & $\begin{array}{c}\mathbf{0 . 0 0 0 0 3 2 2}^{\text {****}} \\
(0.0000105)\end{array}$ & $\begin{array}{c}\mathbf{0 . 0 0 0 0 3 0 0}^{* * *} \\
(0.0000116)\end{array}$ & $\begin{array}{c}\mathbf{0 . 0 0 0 0 3 3 6 ~}^{\text {****}} \\
(0.0000118)\end{array}$ & $\begin{array}{c}\mathbf{0 . 0 0 0 0 3 6 6}^{\text {****}} \\
(0.0000115)\end{array}$ \\
\hline Ln(Gdp) & & & $\begin{array}{l}\mathbf{8 . 0 0 8}^{* * *} \\
(1.471)\end{array}$ & $\begin{array}{l}\mathbf{4 8 . 2 5}^{* * *} \\
(11.74)\end{array}$ & $\begin{array}{l}\mathbf{6 0 . 5 0}^{* * *} \\
(15.79)\end{array}$ & $\begin{array}{c}59.54^{* * *} \\
(15.87)\end{array}$ & $\begin{array}{c}56.47^{* * *} \\
(15.43)\end{array}$ \\
\hline$[\operatorname{Ln}(\mathrm{Gdp})]^{2}$ & & & & $\begin{array}{c}-2.258^{* * *} \\
(0.657)\end{array}$ & $\begin{array}{c}-2.885^{* * *} \\
(0.891)\end{array}$ & $\begin{array}{c}-2.982^{* * *} \\
(0.896)\end{array}$ & $\begin{array}{c}-2.982^{* * *} \\
(0.870)\end{array}$ \\
\hline Lab. reg. index & & & & & $\begin{array}{l}0.00702 \\
(0.0433)\end{array}$ & $\begin{array}{c}0.0192 \\
(0.0439)\end{array}$ & $\begin{array}{c}\mathbf{0 . 1 1 4}^{* *} \\
(0.0449)\end{array}$ \\
\hline Investment & & & & & & $\begin{array}{c}\mathbf{0 . 1 6 2}^{* *} \\
(0.0747)\end{array}$ & $\begin{array}{c}\mathbf{0 . 1 6 9}^{* *} \\
(0.0725)\end{array}$ \\
\hline Schooling & & & & & & & $\begin{array}{l}4.065^{* * *} \\
(0.556)\end{array}$ \\
\hline Ln(popul) & $\begin{array}{l}-5.555^{* *} \\
(2.167)\end{array}$ & $\begin{array}{c}-\mathbf{1 4 . 4 6} \\
(3.112)\end{array}$ & $\begin{array}{c}\mathbf{- 1 2 . 0 7}^{* * *} \\
(3.115)\end{array}$ & $\begin{array}{c}-16.44^{* * *} \\
(3.339)\end{array}$ & $\begin{array}{c}-12.90^{* * *} \\
(4.110)\end{array}$ & $\begin{array}{c}-13.47^{* * *} \\
(4.134)\end{array}$ & $\begin{array}{c}\mathbf{- 1 7 . 8 8} \\
(4.054)\end{array}$ \\
\hline _cons & $\begin{array}{c}\mathbf{1 1 4 . 9}^{\text {****}} \\
(19.13)\end{array}$ & $\begin{array}{c}\mathbf{2 0 8 . 4}^{\text {****}} \\
(29.94)\end{array}$ & $\begin{array}{c}\text { 109.3 }^{\text {**** }} \\
(34.73)\end{array}$ & $\begin{array}{l}-25.62 \\
(51.99)\end{array}$ & $\begin{array}{l}\mathbf{- 1 1 9 . 9}^{*} \\
(63.65)\end{array}$ & $\begin{array}{l}-102.8 \\
(64.41)\end{array}$ & $\begin{array}{c}-62.74 \\
(62.83)\end{array}$ \\
\hline Year dummies & Yes & Yes & Yes & Yes & Yes & Yes & Yes \\
\hline$N$ & 1737 & 1229 & 1229 & 1229 & 1024 & 1024 & 1016 \\
\hline$N$ countries & 82 & 71 & 71 & 71 & 66 & 66 & 64 \\
\hline$R^{2}$ & 0.068 & 0.093 & 0.108 & 0.120 & 0.101 & 0.093 & 0.1476 \\
\hline F test & $168514.1^{* * *}$ & $161637.1^{* * *}$ & $164262.7^{* * *}$ & $166227.3^{* * *}$ & $146390.0 * * *$ & $145064.1^{* * *}$ & $152148.2^{* * *}$ \\
\hline
\end{tabular}

Source: Author's calculations.

Please note: Standard errors in parentheses. ${ }^{*} \mathrm{p}<0.10,{ }^{* *} \mathrm{p}<0.05,{ }^{* * *} \mathrm{p}<0.01 . R^{2}$ is the overall $\mathrm{R}^{2}$. 


\section{Appendix J}

IV estimation. Benchmark specification. Heteroskedasticity robust standard errors.

\begin{tabular}{|c|c|c|c|}
\hline & $\begin{array}{l}\text { 1-year lags } \\
\text { (xtivreg2, fe } \\
\text { robust) } \\
\text { (1) }\end{array}$ & $\begin{array}{l}\text { 1- and 2-year } \\
\text { lags } \\
\text { (xtivreg2, fe } \\
\text { robust) } \\
(2)\end{array}$ & $\begin{array}{l}\text { 1-, } 2 \text { - and 3- } \\
\text { year lags } \\
\text { (xtivreg2, fe } \\
\text { robust) } \\
(3)\end{array}$ \\
\hline Openness & $\begin{array}{l}\mathbf{0 . 0 3 8 7}^{* *} \\
(0.0165)\end{array}$ & $\begin{array}{c}\mathbf{0 . 0 3 3 7}^{*} \\
(0.0180)\end{array}$ & $\begin{array}{c}0.0286 \\
(0.0201)\end{array}$ \\
\hline Patents & $\begin{array}{l}\mathbf{0 . 0 0 0 0 3 6 6}^{\text {****}} \\
(0.00000958)\end{array}$ & $\begin{array}{l}\mathbf{0 . 0 0 0 0 2 7 3}^{* * *} \\
(0.00000968)\end{array}$ & $\begin{array}{c}\mathbf{0 . 0 0 0 0 2 3 8}^{* *} \\
(0.00000973)\end{array}$ \\
\hline Ln(Gdp) & $\begin{array}{l}56.47^{* * *} \\
(18.01)\end{array}$ & $\begin{array}{l}\mathbf{4 7 . 7 8}^{* *} \\
(19.24)\end{array}$ & $\begin{array}{l}\mathbf{4 7 . 9 6}^{* *} \\
(22.29)\end{array}$ \\
\hline$[\operatorname{Ln}(\mathrm{Gdp})]^{2}$ & $\begin{array}{c}-2.982^{* * *} \\
(1.027)\end{array}$ & $\begin{array}{l}-2.491^{* *} \\
(1.084)\end{array}$ & $\begin{array}{l}-2.473^{* *} \\
(1.250)\end{array}$ \\
\hline Lab. reg. index & $\begin{array}{l}\mathbf{0 . 1 1 4}^{* *} \\
(0.0444)\end{array}$ & $\begin{array}{c}0.0685 \\
(0.0466)\end{array}$ & $\begin{array}{c}0.0652 \\
(0.0508)\end{array}$ \\
\hline Investment & $\begin{array}{c}\mathbf{0 . 1 6 9}^{*} \\
(0.0956)\end{array}$ & $\begin{array}{c}\mathbf{0 . 2 1 0}^{* *} \\
(0.0873)\end{array}$ & $\begin{array}{c}\mathbf{0 . 2 4 4}^{\text {** }} \\
(0.0998)\end{array}$ \\
\hline Schooling & $\begin{array}{l}\mathbf{4 . 0 6 5}^{* * *} \\
(0.534)\end{array}$ & $\begin{array}{l}\mathbf{4 . 1 0 9}^{* * *} \\
(0.535)\end{array}$ & $\begin{array}{l}\mathbf{4 . 1 7 3}^{* * *} \\
(0.551)\end{array}$ \\
\hline Ln(popul) & $\begin{array}{c}\mathbf{- 1 7 . 8 8} \\
(5.036) \\
\end{array}$ & $\begin{array}{c}-\mathbf{1 5 . 6 7} \\
(5.435) \\
\end{array}$ & $\begin{array}{c}\mathbf{- 1 3 . 1 9}{ }^{* *} \\
(6.219) \\
\end{array}$ \\
\hline Year dummies & Yes & Yes & Yes \\
\hline$N$ & 1015 & 924 & 842 \\
\hline$N$ of countries & 63 & 61 & 59 \\
\hline$R^{2}$ & 0.148 & 0.163 & 0.177 \\
\hline$F$ test & $4.20 * * *$ & $4.30 * * *$ & $4.49 * * *$ \\
\hline
\end{tabular}

Source: Author's calculations.

Standard errors in parentheses. ${ }^{*} \mathrm{p}<0.10,{ }^{* *} \mathrm{p}<0.05,{ }^{* * *} \mathrm{p}<0.01 . R^{2}$ is the within $\mathrm{R}^{2}$. 